\title{
The effects of controlled environmental and physical factors on the physiological responses of the handfinger system
}

John Kaiser

Follow this and additional works at: https://researchrepository.wvu.edu/etd

\section{Recommended Citation}

Kaiser, John, "The effects of controlled environmental and physical factors on the physiological responses of the handfinger system" (2016). Graduate Theses, Dissertations, and Problem Reports. 5920. https://researchrepository.wvu.edu/etd/5920

This Thesis is protected by copyright and/or related rights. It has been brought to you by the The Research Repository @ WVU with permission from the rights-holder(s). You are free to use this Thesis in any way that is permitted by the copyright and related rights legislation that applies to your use. For other uses you must obtain permission from the rights-holder(s) directly, unless additional rights are indicated by a Creative Commons license in the record and/ or on the work itself. This Thesis has been accepted for inclusion in WVU Graduate Theses, Dissertations, and Problem Reports collection by an authorized administrator of The Research Repository @ WVU. For more information, please contact researchrepository@mail.wvu.edu. 


\title{
The effects of controlled environmental and physical factors on the physiological responses of the hand- finger system
}

\author{
John Kaiser
}

Thesis submitted

to the Benjamin M. Statler College of Engineering and Mineral Resources at West Virginia University

in partial fulfillment of the requirements for the degree of

Master of Science in

Industrial Management and Systems Engineering

Ashish D. Nimbarte, Ph.D., Chairperson

Bhaskaran Gopalakrishnan, Ph.D., PE, CEM

Xinjian He, Ph.D.

Department of Industrial Management and Systems Engineering

Morgantown, West Virginia

2016

Keywords: Onycholysis, musculoskeletal disorder (MSD), skin conductance, blood perfusion, perceived discomfort, hand injury, glove injury

Copyright 2016 John Kaiser 


\begin{abstract}
The effects of controlled environmental and physical factors on the physiological responses of the hand-finger system
\end{abstract}

\author{
John Kaiser
}

Hand injuries account for a leading cause of occupational injuries requiring treatment from United States' hospital emergency departments. These occupational injuries generate a substantial burden on employers in terms of both cost and productivity. Occupational safety gloves are an effective preventive measure of these hand and finger injuries. However, these occupational safety gloves can result in unintended injuries due to factors such as extreme conditions of temperature, relative humidity, and physical demand. The purpose of this study is to collect data on the physiological responses of the hand-finger system and their relationship with these identified factors. The physiological responses measured were skin conductance, blood perfusion, and perceived discomfort. A chamber was used to isolate human subjects' hands and precisely control the conditions of temperature and relative humidity to replicate the internal conditions within occupational safety gloves. Seventeen human subjects each performed three hours of experimental trials that routinely required the physical exertion of lateral pinching. The microclimate condition of temperature was shown to have a significant effect on perceived discomfort and skin conductance. The microclimate condition of relative humidity was shown to have a significant effect on skin conductance. The occupational condition of repetitive physical demand was shown to have a significant effect on perceived discomfort, skin conductance, and blood perfusion. The results of this study may assist ergonomists in selecting or suggesting occupational gloves for workers while minimizing risk of injury. 


\section{Acknowledgements}

I would like to express my appreciation for my advisor, Dr. Ashish Nimbarte. He has provided great leadership, continuous effort, and support throughout my graduate education. He has been much more than an advisor and with his support I have been able to maximize my graduate education success and achievements.

I would like to express my appreciation for my committee member, Dr. Bhaskaran Gopalakrishnan. Dr. Bhaskaran Gopalakrishnan is a great professor, leader, and supporter. He has always shown great concern and consideration for his students and their success. As a committee member, Dr. Bhaskaran Gopalakrishnan has been very supportive and provided helpful feedback.

I would like to express my appreciation for my committee member, Dr. Xinjian He. Throughout his time as my committee member, Dr. Xinjian He has always made himself available and has provided insight that has greatly improved the value of my thesis. 


\section{Table of Contents}

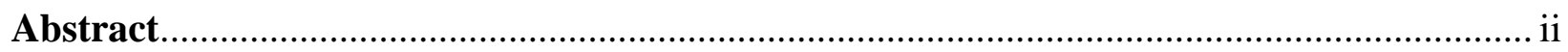

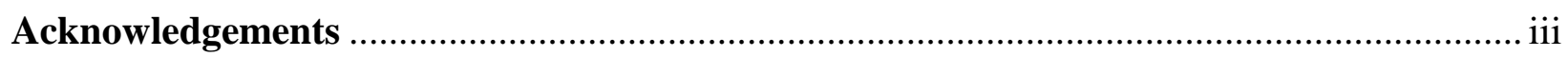



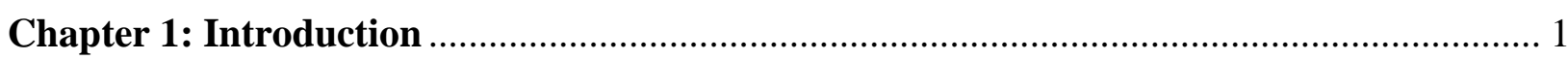



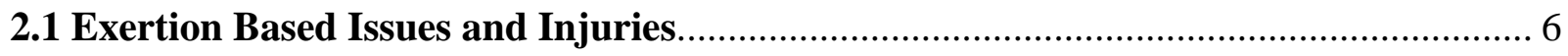

2.2 Glove Occlusion Injuries ................................................................................ 7

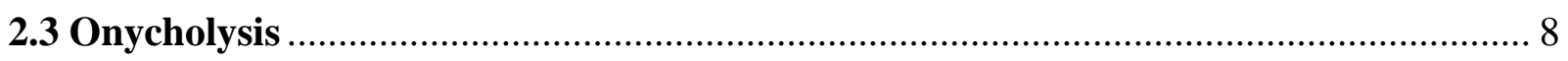

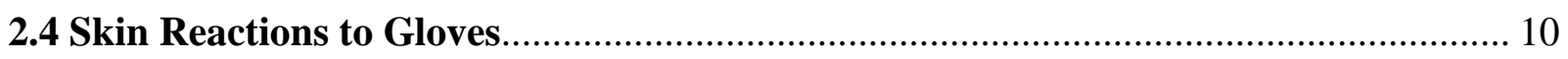

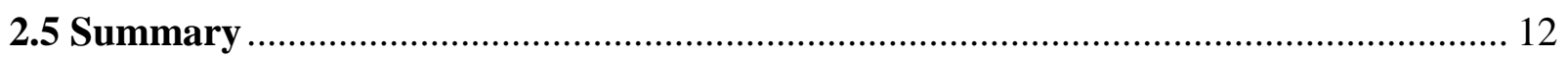

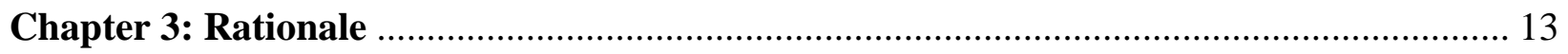



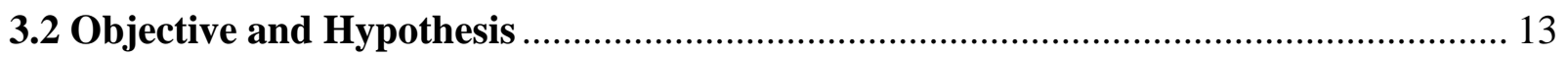

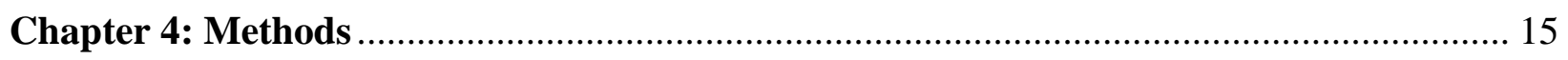



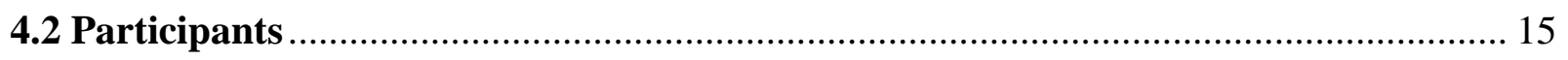

4.2.1 Sample Size Estimation ................................................................................... 15

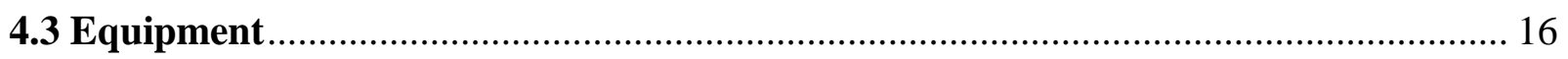

4.3.1 Custom Built Microclimate Chamber ................................................................ 16

4.3.2 Skin Conductance Sensor ............................................................................ 18

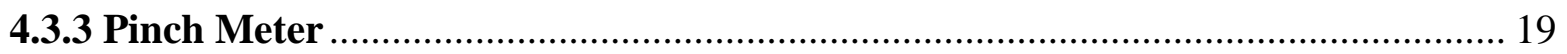

4.3.4 Laser Doppler Perfusion Monitor (LDPM) ...................................................... 19



4.5 Experimental Data Collection Procedure ......................................................... 21



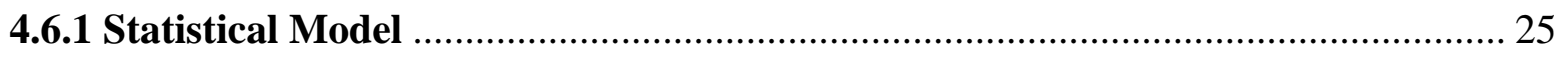

4.6.2 Data Normalization and Validity for Statistical Analysis................................ 27

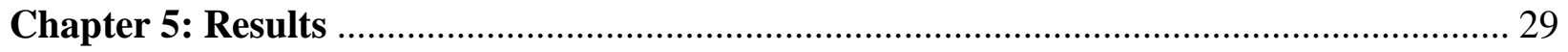

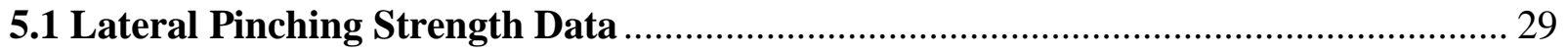

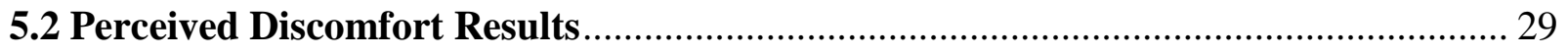

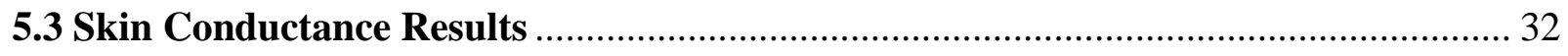






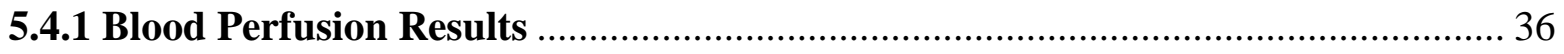

5.4.2 Blood Perfusion Results of Modified Exertion Trials .......................................... 40

Chapter 6: Discussion and Conclusions............................................................................ 43

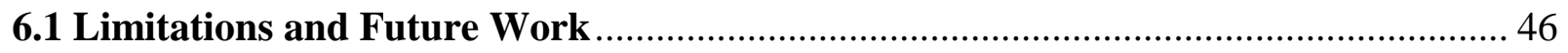

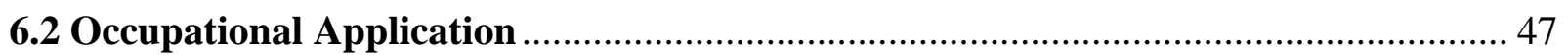

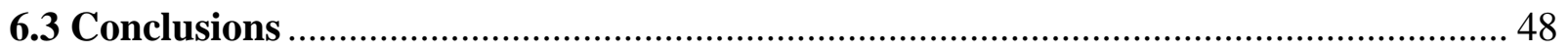

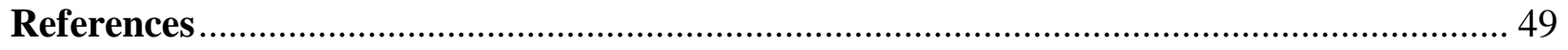

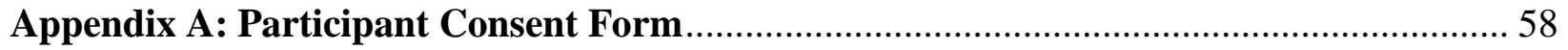

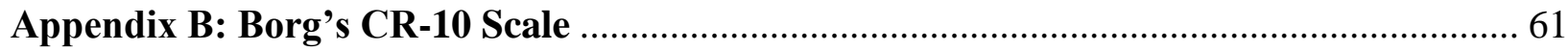

Appendix C: Perceived Discomfort Data Table …….......................................................... 62

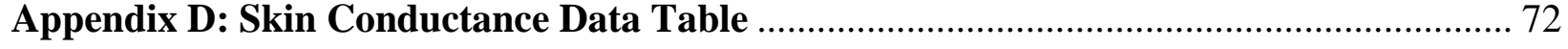

Appendix E: Blood Perfusion Data Table (No Exertion V.S. Exertion) ................................. 85

Appendix F: Blood Perfusion Data Table (Intermediate Exertion V.S. Exertion) ................. 89

Appendix G: Skin Conductance Normality Test ……....................................................... 95

Appendix H: Normalized Skin Conductance Normality Test .............................................. 96

Appendix I: Normalized Skin Conductance Equality of Variance Test................................. 97

Appendix J: Perceived Discomfort Normality Test ……....................................................... 98

Appendix K: Normalized Perceived Discomfort Normality Test ......................................... 99

Appendix L: Normalized Perceived Discomfort Equality of Variance Test ........................ 100

Appendix M: Blood Perfusion (Exertion Trial V.S. No Exertion Trial) Equality of Variance

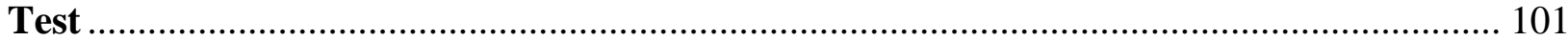

Appendix N: Blood Perfusion (Exertion V.S. Intermediate Exertion) Equality of Variance Test

Appendix O: Blood Perfusion (Exertion Trial V.S. No Exertion Trial) Normality of Residuals

Appendix P: Blood Perfusion (Exertion V.S. Intermediate Exertion) Normality of Residuals 104 


\section{Chapter 1: Introduction}

Hand injuries have been repeatedly identified as one of the most frequent anatomical locations affected by work related injuries (Sorock, 2001) (Duncan, Sanati, and Macdonald, 2012). The United States Department of Labor's Occupational Safety and Health Administration (OSHA) has attempted to address this issue by creating a specific occupational hand protection standard. This standard states that "Employers shall select and require employees to use appropriate hand protection when employees' hands are exposed to hazards such as those from skin absorption of harmful substances; severe cuts or lacerations; severe abrasions; punctures; chemical burns; thermal burns; and harmful temperature extremes" (U.S. Dept of Labor, 1994). To protect against these different types of hazards employers have implemented the usage of a variety of gloves for hand protection.

These gloves can be used for the purpose of general protection or designed to mitigate a particular hazard (Riley and Cochran, 1988). In order to effectively address specific hazards, great variation exists in the design and materials of different occupational gloves.

This variation is evident in the occupational gloves used by U.S. astronauts during Extra Vehicular Activity (EVA). Extra Vehicular Activity (EVA) involves any activity performed outside the spacecraft. These EVA gloves are designed to protect the astronaut's hands from the specific hazards of the extreme occupational conditions (Figure 1.1). Due to these specific hazards the EVA gloves are designed with 3 different layers, each with its own purpose in the overall goal of protecting the astronaut (Bishu and Muralidhar, 1999; Figure 1.2). These gloves are much different than aluminized occupational safety gloves, which are used to protect individuals, such as firefighters, against the hazards of extreme radiant heat and flames (Chou, 
2011; Figure 1.3). These gloves address very different hazards but apply to the same overall goal of providing hand protection to the worker and prevent occupational hand injuries.

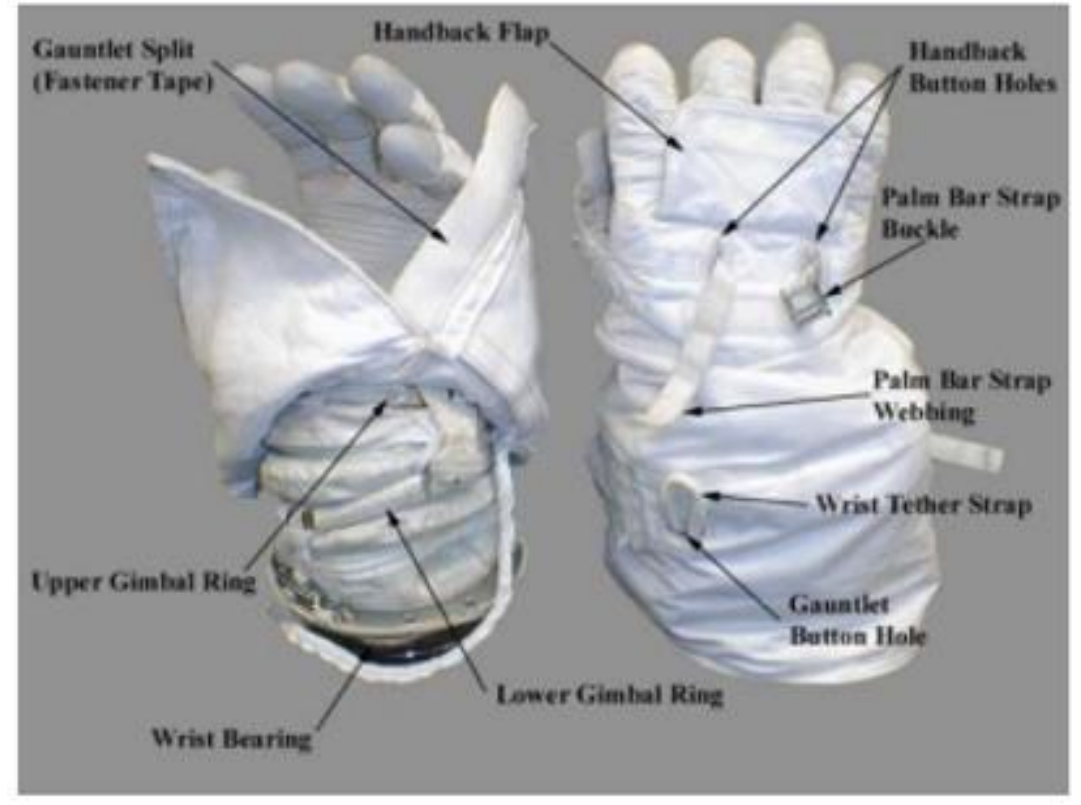

Figure 1.1: Phase VI Glove Assembly

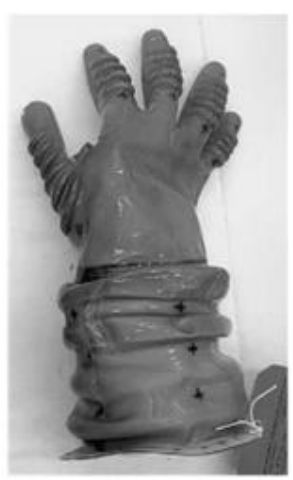

(a)

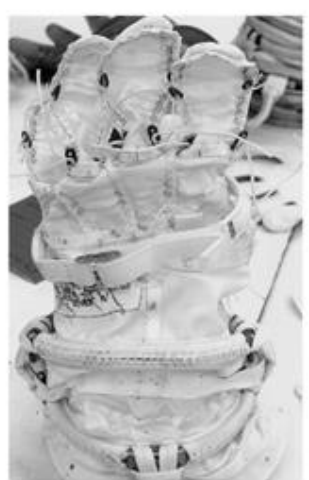

(b)

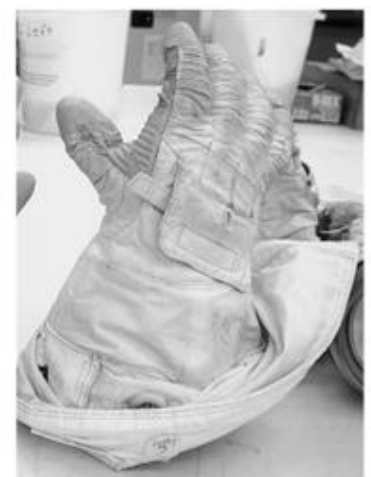

(c)

Figure 1.2: Phase VI Glove Three Layers (a) Inner Bladder Lining; (b) Restrainer; (c) Outer Glove Layer 


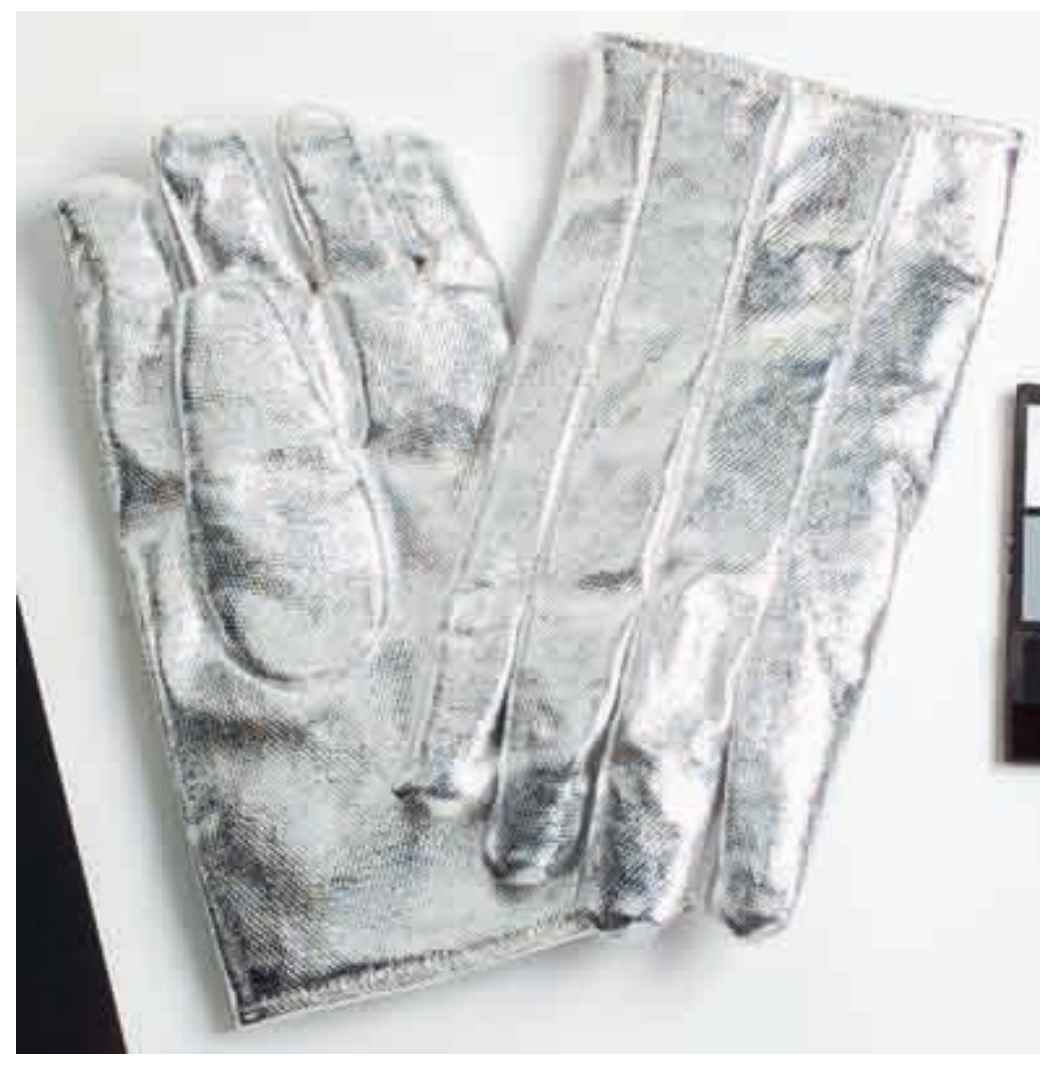

Figure 1.3: Aluminized Occupational Safety Gloves

The usage of occupational safety gloves is suggested frequently. However, this usage of occupational safety gloves can result in negative or unintended issues and injuries (Dianat et al., 2012). These issues vary greatly and affect many industries in different ways ranging from performance to safety (Dianat at al., 2012). Performance issues can be related to productivity in terms of reduction in tactile dexterity, gripping strength, and other measures of physical performance. Safety issues can be related to occupational injury in terms of insufficient protection, skin reactions, musculoskeletal disorders (MSD), and many others (Dianat et al., 2012).

These occupational glove-hand injuries are diverse in conditions present, pathogenesis, severity, and occupations affected. This diversity has made addressing these injuries as a whole a complex issue. Significant glove-hand injuries are among many occupations including 
individuals who are nurses, doctors, astronauts, hairdressers and production workers (Taylor, 1996; Poole, 2007; Viegas et al., 2004; Wulfhorst, 2004; Weistenhöfer, 2015). In the healthcare industry much research has been dedicated to the occurrence of skin reactions such as glove dermatitis, irritation, and allergy (Trape et al., 2000; Rose et al., 2009). In the U.S. Space Program an area of research is focused on understanding the occurrence of Onycholysis. Both of these glove-hand injuries are very different in terms of symptoms and occupational conditions present during onset. However, in both occupations, the physiological responses of the handfinger system to the occupational conditions have been identified as significant in understanding the pathogenesis of the stated injuries. Specifically the physiological responses of skin conductance, perceived discomfort, and blood perfusion of the hand-finger system to the environmental conditions of the microclimate or microenvironment within the occupational safety gloves (Reid and McFarland, 2015; Amick at el. 2016; Ansari et al. 2009). The physiological responses to the occupational demand of repetitive physical exertions have also been identified as significant in understanding the pathogenesis of several occupational glove injuries (Viegas et al. 2004).

This demonstrates the multiple applications and benefits from an improved understanding of the physiological responses of the hand-finger system to microclimate conditions and physical exertion demand. In this research, a lab based study with human subjects was conducted to study the physiological responses of the hand-finger system to environments similar to the microclimates within occupational safety gloves and the occupational condition of physical exertion demand. This is a significant contribution because an improved understanding of the physiological responses of the hand-finger system to these factors may provide crucial information in better understanding several glove-hand occupational injuries. An improved 
understanding of these glove-hand occupational injuries may allow better intervention and prevention of such injuries. 


\section{Chapter 2: Literature Review}

In previous studies that focused on the occupational glove injuries several different methodologies were utilized. These methodologies were largely dependent upon the type of injury and relevant factors being studied. In this chapter the focus is on occupational glove injuries in which the physiological responses of the hand-finger system to the microclimate of the glove and the occupation condition of physical demand have been identified as significant. The specific microclimate conditions of interest are high temperature and high relative humidity. In addition, the specific physical demand condition of interest is forceful repetitive exertions. These injuries can be broadly grouped into four categories: exertion based injuries, glove occlusion injuries, Onycholysis, and skin reactions to gloves. Below is a brief review of these studies and their relevant findings.

\subsection{Exertion Based Issues and Injuries}

Gloves can have a negative effect of increasing effort and physical exertion necessary to perform a task. This is can be observed in a reduction in dexterity, tactile sensitivity, hand strength and range of motion (Bradley, 1969a; Sawyer and Bennet, 2006; Bellingar and Slocum, 1993; Bensel, 1993; Bishu and Klute, 1995; Shih et al., 2001; Dianat et al., 2010; Dianat et al., 2012; Thompson et al., 2011; Willms et al., 2010). Many occupations require occupational safety gloves and due to gloves increasing the level of force required of the forearm muscles, long term use of these gloves has shown an increase the biomechanical stress on the tendons which is contributing factor to cumulative damage (Kovacs et al., 2002).

It has also been identified that the usage of gloves may be a contributing factor to musculoskeletal disorder (MSD) in repetitive manual tasks (Armstrong, 1986; Chengular et al., 2004). Furthermore it has been shown that extreme temperature may be a causative factor for 
cumulative trauma disorders (Ross, 1994). Temperature has been shown to have a significant impact on dexterity and strength (Chen, Shin, and Chi, 2010). This information highlights the importance of reviewing the effect physical exertions and extreme temperature have on the physiological responses of the hand-finger system.

\subsection{Glove Occlusion Injuries}

Occlusive gloves are an attribute of gloves including occupational safety gloves. This attribute is utilized throughout several industries and can be made from a wide variety of materials. However, glove occlusion is one significant cause of glove irritation and macerated softened skin which results in additional issues due to its' poor protection against microbes and chemical injuries (Wulfhorst, 2004). This glove occlusion effect results in a microclimate or microenvironment that exists between the user's hand and the glove (Bishop, Gu, and Clapp, 2000). This microenvironment usually becomes warmer and more humid than the ambient environment because of the production of metabolic heat and sweat by the worker (Bishop, Gu, and Clapp, 2000). The amount of sweat produced on the skin depends on a number of variables including protective clothing material, activity level, and task performance (Havenith et al., 2002). Glove comfort seems to be proportional to the ability of the gloves to absorb the sweat and keeps the hands dry. This is due to evidence shown that discomfort of the hands tends to increase with increasing quantities of sweat generation (Gnaneswaran, Mudhunuri, and Bishu, 2008). The evaporation rate of sweat is critical to thermal equilibrium and is directly affected by humidity within the gloves (Bernard and Matheen, 1999). Thermal parameters such as insulation and water vapor permeability of the clothing, are important factors to temperature and relative humidity within the gloves (Bernard and Matheen, 1999). Thus, the inability to control thermal 
equilibrium can lead to discomfort due to the potential of a high temperature and high relative humidity microclimate becoming present.

Extreme humidity conditions within this microclimate are also known to subject the workers to emotional stress (Muggleton, Allen, and Chappell, 1999). The high humidity of the microclimate is also link to the onset of the condition known as subcutaneous cellulitis of the hand (Muggleton, Allen, and Chappell, 1999). This condition involves bruising and devitalization of the tissues within the hand (Muggleton, Allen, and Chappell, 1999). Symptoms for this condition are pain, discomfort, and loss of function (Muggleton, Allen, and Chappell, 1999). This is accompanied by tenderness, swelling, redness, and heat (Muggleton, Allen, and Chappell, 1999).

Several countermeasures have been tested in reducing the high extremes of temperature and relative humidity of the microenvironment. Two techniques tested in one study were the usage of ambient air-ventilated vest and water spraying of the skin (Ciuha et al., 2015). Both cooling strategies resulted in improving evaporative cooling and reducing heat strain (Ciuha et al., 2015). When an extension of the air circulation was added a reduction in both skin moisture and discomfort were observed (Jones et al., 2008).

Despite the identified injuries and the causal relationship of such injuries with the use of occupational gloves, the relationship between environmental factors, physical factors, and the physiological responses of the hand-finger system to these factors are not completely understood.

\subsection{Onycholysis}

The most common locations of injury during EVA for astronauts is the hand and fingers (Jones et al., 2007; Scheuring et al., 2009; Strauss et al., 2005). These hand and finger injuries also often occur during the training associated with EVA (Charvat et al., 2015). These injuries 
and other events often lead to a fingernail condition known as Onycholysis (Figure 2.1). Onycholysis is a condition where the victim's nail separates from the nail bed and is often accompanied by the physiological response of discomfort or pain (Charvat et al., 2015). The astronauts' middle fingernails have been reported as the most frequently affected fingernails by Onycholysis (Charvat et al., 2015).



\section{Figure 2.1: Condition of Onycholysis}

One identified factor associated with Onycholysis is the accumulation of moisture on the skin in a high relative humidity environment (Jones et al., 2008; Reid and McFarland, 2015). High relative humidity, high temperature, and high skin moisture have all been identified as characteristics of the atmospheric conditions and physiological responses occurring within astronauts' gloves during EVA and related training (Charvat et al., 2015). As stated before, a reduction in skin moisture has been shown to reduce hand and finger discomfort (Jones et al., 2008). The physiological response of skin moisture has been repeatedly identified as a possible risk factor for the occurrence of Onycholysis among U.S. Astronauts during EVA and associated training (Jones et al., 2008; Tanaka, Nakamura, and Katafuchi, 2014; Charvat et al., 2015; Strauss, 2004; Amick et al., 2016).

The physiological factor of blood perfusion has been examined as well (Reid and McFarland, 2015; Amick at el. 2016). The measurement of blood perfusion can prove helpful in 
mitigating the risk of Onycholysis because blood perfusion is a primary factor in the transportation of oxygen, nutrients, and other important materials (Ansari et al., 2009; Reid and McFarland, 2015). Furthermore, a reduction in blood perfusion due to contact pressure has been linked to discomfort (Ansari et al., 2009). The literature has also stated that fingertip discomfort and pain associated with EVA and related training is partially due to reduced blood flow caused by contact pressure (Ansari et al., 2009). The blood flow has been shown to be reduced in the hand-finger system by up to $50 \%$ when performing gripping exertions (Ansari et al., 2009). In addition, blood perfusion peaked and dropped during finger presses (Reid et al., 2014). This blood hyper-perfusion has been theorized to be a main contributor to Onycholysis (Ansari et al., 2009). It is further showed that forces on the hand and finger can affect the blood flow to the fingertip (Ansari et al., 2009).

Despite the high prevalence of hand injuries amongst U.S. astronauts and the causal relationship of such injuries with the use of EVA gloves, the relationship between environmental factors, physical factors, and the physiological responses of the hand-finger system to these factors are not completely understood.

\subsection{Skin Reactions to Gloves}

Specific skin reactions to occupational safety gloves can result in injuries such as glove dermatitis, irritation, and allergy (Trape et al., 2000, Rose et al., 2009) (Alessio et al., 1997; Turjanmaa K, 2002; Turjanmaa, 1987; Turjanmaa K, 1988). The severity and condition of the skin reaction or allergy can vary greatly when comparing individuals and can be very dependent upon the material used in the design of the glove (Turjanmaa K et al. 1988; Trape et al., 2000; Rose et al., 2009; Alessio et al., 1997; Turjanmaa K, 2002; Turjanmaa, 1987). 
In the healthcare industry the usage of natural rubber latex (NRL) gloves is very common. The level of usage was due to safety measures to protect the healthcare professional from blood-borne pathogens (Packham, 2006; Harnoss et al., 2010; Tanner, 2007). The implementation of these latex gloves as general gloves was accompanied by a high increase in the occurrence of latex allergy (Packham, 2006). Latex allergy is a type I reaction to natural rubber latex (NRL) proteins with clinical manifestations ranging from contact urticaria to fatal anaphylaxis (Taylor, 1996; Poole, 2007). However, it was determined that this reaction was due to the powder within the gloves. (Packham, 2006; Turjanmaa K, 2002). In Germany, powdered NRL gloves were banned from healthcare use and this has resulted in a reduction in the occurrence of latex allergy that is similar to other unexposed populations. (Packham, 2006; Allmers et al., 2002). However, it is important note the issue of skin reactions to glove material is not completely resolved with this countermeasure (Turjanmaa K, 2002).

The physiological response to the microclimate within the gloves has also been identified as being involved in understanding the pathogenesis of this skin reaction. Within these gloves heat and moisture may collect due to the occlusion effect (Tsai, Tsen-Fang, and Maibach, 1999) (Lynde, 2008). The barrier function of the skin may be further impaired by occlusion (Behroozy, Ali, and Keegel, 2014). The physiology of the skin might be changed by occlusion and this may facilitate the activation of other potential irritants (Behroozy, Ali, and Keegel, 2014; Schäfer et al., 2002).

Despite the identified injuries and causal relationship of such injuries with the use of occupational gloves, the relationship between environmental factors, physical factors, and the physiological responses of the hand-finger system to these factors are not completely understood. 


\subsection{Summary}

These identified occupational injuries, issues, and other conditions that directly affect the worker's health and effectiveness are diverse in many attributes and characteristics. These attributes and characteristics include, but are not limited to, the occupations effected, the types of gloves used, the level of training required for the occupation, the duration of the injury, the economic cost of the injury and the availability of effective countermeasures.

However, the similarities of these diverse occupational injuries, issues, and other conditions in terms of relevant physiological responses and occupational conditions could provide important insight into the occurrence of these occupational events. These injuries, issues, and other conditions are occurring at or involving the anatomical location of the hand-finger system. These injuries, issues, and other conditions are occurring during the usage of occupational gloves. Furthermore, these injuries, issues, and other conditions have identified the microclimate conditions of the occupational gloves in terms of temperature and relative humidity and the occupational demand of physical exertion as significant factors. Lastly, these injuries, issues, and other conditions have identified the physiological responses of perceived discomfort, skin conductance, and blood perfusion as significant factors regarding the pathogenesis of these occupational events.

An understanding of the relationship of the identified occupational factors have with the identified physiological responses would potentially have an impact on a diverse group of injuries. This understanding has been identified as important but is currently limited. 


\section{Chapter 3: Rationale}

\subsection{Problem Statement}

Occupational glove-hand injuries are a prevalent issue in the modern working population. Past studies have identified several different injuries and issues that are associated with the interaction of the glove and hand and the hand's physiological responses to the environmental and occupational factors. A number of previous studies have reported on the significance of extreme temperature, relative humidity, repetitive physical exertion, skin conductance, discomfort, and blood perfusion in the causation of glove-hand injuries. However, a complete understanding of these occupational conditions and their relationship on the physiological responses does not exist. Therefore, a critical need exists for the improvement of this relationship through the systematic collection of physiological response data from human subjects in controlled conditions of temperature, relative humidity, and physical exertion.

\subsection{Objective and Hypothesis}

The objective in this study was to quantify the effect of the following three previously identified risk factors on the physiological state of the hand-finger system.

1) Temperature

2) Humidity

3) Physical exertions

The Null Hypothesis was that the temperature, humidity and physical exertion have no main and interaction effects on the physiological responses of the hand-finger system. The physiological response of hand-finger system was measured using the following three identified physiological responses. 
1. Skin conductance

2. Blood perfusion

3. Perceived discomfort

To be specific, each of the three identified risk factors will be tested for their main and interaction effects on each of the three identified physiological responses. Successful completion of this proposed study will allow clear understanding of these identified risk factors' effects on the identified physiological responses of the hand-finger system. This is expected improve our pathophysiologic understanding of occupational glove injuries. 


\section{Chapter 4: Methods}

\subsection{Approach}

A laboratory-based experimental study involving human subjects was completed. During the experiment, the participant's dominant hand was isolated and exposed to different occupational conditions of temperature, relative humidity, and physical exertion within a controlled chamber. The physiological response of the hand-finger system was measured using a skin conductance sensor, a blood perfusion sensor, and recordings of participants perceived discomfort levels.

\subsection{Participants}

A total of 17 participants were recruited for the current research. Participants were excluded from the research if they suffered from any type of musculoskeletal, degenerative, or neurological disorder or if they had a history of hand or fingertip pain or any current pain.

\subsubsection{Sample Size Estimation}

The statistical power based on the sample size of $\mathrm{N}$ participants was estimated using the operating characteristics curves (OC curves) based on the following equation:

$$
\boldsymbol{\varphi}=\sqrt{\frac{n D^{2}}{2 a \sigma^{2}}}
$$

Where, $\boldsymbol{\varphi}$ : noncentrality parameter

n: number of participants

D: meaningful maximum differences between the physical exertion conditions

a: number of physical exertion conditions

$\sigma^{2}$ : estimate of the variance 
For estimating the sample size we used the effect of physical exertion on skin conductance as a representative variable. From previous experiments, we estimate $\sigma^{2}$ to be 0.3 $\mu \mathrm{S}$. We proposed that a difference of $0.5 \mu \mathrm{S}$ between the physical exertion conditions was meaningful for our study. This was tested at the 0.05 level of significance. Thus, based on these figures, for a $90 \%$ power a sample size of 10 participants is sufficient (Table 1). However, we increased the sample size to 17 subjects to guard against the possibility that the prior estimate of the standard deviation was too conservative.

\begin{tabular}{|cccccc|}
\hline \multicolumn{7}{|c|}{ Table 1: Sample Size Calculations } \\
\hline $\mathbf{N}$ & $\mathrm{v} 1$ & $\mathrm{v} 2$ & $\boldsymbol{\varphi}$ & $\beta$ & $\begin{array}{c}\text { Power } \\
(1-\beta)\end{array}$ \\
\hline $\mathbf{5}$ & 1 & 8 & 1.863 & 0.39 & 0.61 \\
\hline $\mathbf{6}$ & 1 & 10 & 2.041 & 0.26 & 0.74 \\
\hline $\mathbf{7}$ & 1 & 12 & 2.205 & 0.19 & 0.81 \\
\hline $\mathbf{8}$ & 1 & 14 & 2.357 & 0.13 & 0.87 \\
\hline $\mathbf{1 0}$ & 1 & 18 & 2.635 & 0.06 & 0.94 \\
\hline
\end{tabular}

\subsection{Equipment}

\subsubsection{Custom Built Microclimate Chamber}

This chamber consists of acrylic glass and is approximately $8 \mathrm{ft}^{3}$ in volume (Figure 4.1(a)). The material was chosen due to its insulating properties. The chamber was assembled with 5 pieces of the acrylic glass each approximately $2 \mathrm{ft}$ in height and length. The chamber was assembled similar to a cube and the sides were bonded together with a chemical agent. However, the base was purposely left open to allow access within the chamber without the need for a door. This was added to the design to prevent potential loss of control over atmospheric conditions within the chamber, due to the necessity of moving parts and additional openings for a door. The 
base of the chamber was raised to approximately hip height to allow comfortable access for the participants. The chamber's structure consists of three other openings, not including the base.

One large opening was adapted with a waterproof medical cast cover that allowed the human subject to place their hand within the chamber. This allows for an air tight seal around the human subject's wrist, and provides additional control over the atmospheric conditions within the chamber. Another smaller opening was added to the side to allow entry for the temperature control device's probe (Figure 4.1(b)). The last opening was added to allow an electrical wire that supplied power to the inside of the chamber for all necessary devices. These holes were purposely designed to be as small as possible to reduce potential loss of control over atmospheric conditions. The base of the chamber was placed on an elevated platform with bath towels for flooring. The bath towels were chosen due to their insulating and form fitting properties.



(a)

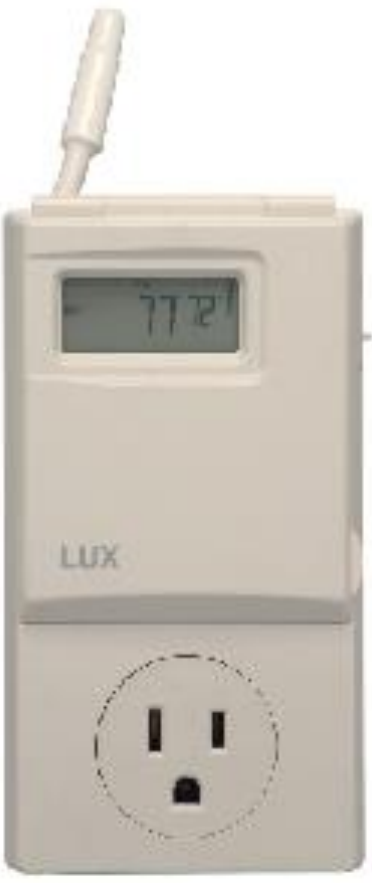

(b)

Figure 4.1: Experimental Equipment: (a) Custom Built Atmospheric Chamber; (b) Temperature Control Device 


\subsubsection{Skin Conductance Sensor}

The skin conductance data were collected through a non-invasive, two probe, skin conductance sensor (SA9309M, ThoughtTechnology, Quebec, Canada). The device consists of two sensor probes that make contact with the skin directly using finger straps (Figure 4.2(a)). This sensor measured and tracked, in real time, the skin conductance data with units of microsiemens. This data was transmitted through a signal isolator (T9405AM, ThoughtTechnology, Quebec, Canada) (Figure 4.2(b)) which allowed the skin conductance sensor to be interfaced with a TeleMyo 2400R G2 receiver (Noraxon USA Inc., Scottsdale, AZ). The MyoResearch XP analysis software (Noraxon USA Inc., Scottsdale, AZ, USA) was used to collect, organize, and analyze the collected data. The skin conductance or skin moisture data was collected from extremely consistent locations of the participant's dominant hand. In addition, the position of the hand, supination, was consistently controlled before collection. The location chosen for data collection of skin conductance is comparable to a similar prior study (Jones et al., 2008).

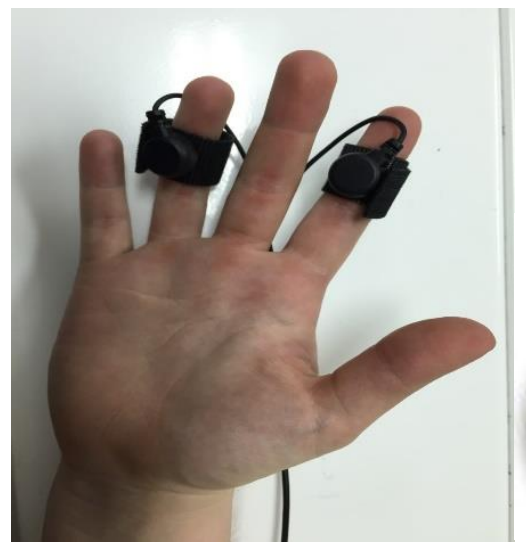

(a)

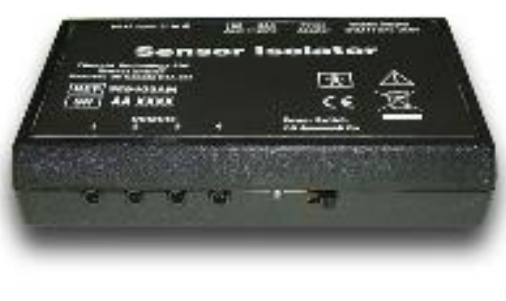

(b)

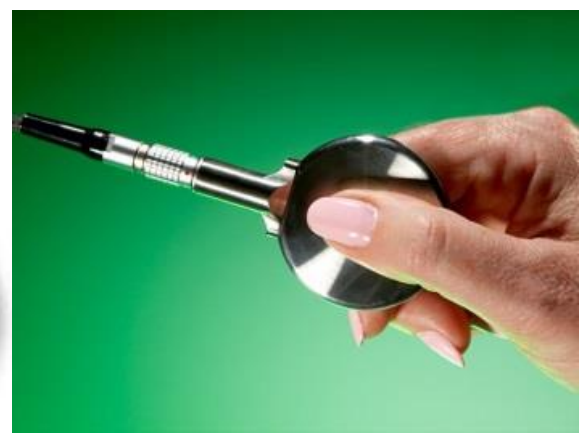

(c)

Figure 4.2: Physiological Response Measuring Equipment: (a) Two Probe Skin Conductance Sensor with Finger Straps; (b) Signal Isolator; (c) Pinch Meter 


\subsubsection{Pinch Meter}

The pinching exertion data, which was generated by the human participants, was obtained with a pinch meter (P200, Biometrics, Newport, United Kingdom) (Figure 4.2(c)). The pinch meter was directly wired to the wireless TeleMyo 2400R G2 transmitter (Noraxon USA Inc, Scottsdale, AZ, USA) that forwarded the data to the TeleMyo 2400R G2 receiver (Noraxon USA Inc., Scottsdale, AZ, USA). The MyoResearch XP analysis software (Noraxon USA Inc., Scottsdale, AZ, USA) was used to collect, organize, and analyze the data. The pinching exertion data was recorded in units of Newtons.

\subsubsection{Laser Doppler Perfusion Monitor (LDPM)}

The blood perfusion data, which was generated by the human participants, was obtained using the Periflux System 5000 laser doppler perfusion monitor (LDPM) (Perimed, Stockholm, Sweden). The LPDM was directly wired to a lab computer via USB port. The PeriSoft analysis software (Perimed, Stockholm, Sweden) was used to collect, organize, and analyze the data. The blood perfusion data was presented in units of blood perfusion. The non-invasive probe was attached to the subject's palm, below the index finger, in a way so the subject's pinching ability wasn't impeded (Figure 4.3). This is the same type of equipment used in other previous studies involving EVA that wish to record blood perfusion data (Reid and McFarland 2015; Amick et al., 2016). This equipment was calibrated before any data collection for each subject. The placement of the blood perfusion probe was also located and adhered to the subject's hand using adhesive tape to match the methodology used in previous studies (Ansari et al., 2009; Reid and McFarland 2015) (Figure 4.3). 


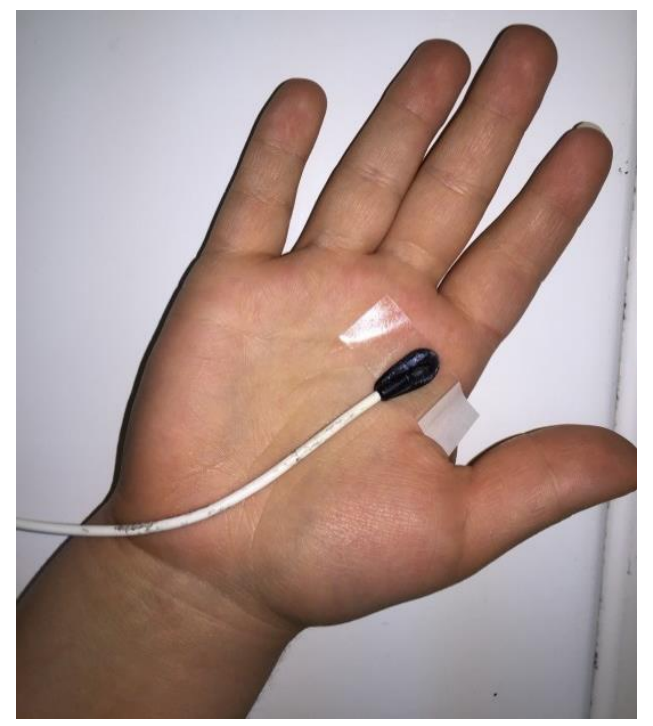

Figure 4.3: Blood Perfusion Probe Placement

\subsection{Experimental Design}

A three-factor replicated block design was used in this research. Factor 1, pinching exertion, was treated at two levels: 1) Exertion, and 2) No Exertion. Factor 2, temperature, was treated at two levels: 1) $65-75^{\circ} \mathrm{F}$, and 2) $85-95^{\circ} \mathrm{F}$. Factor 3 , relative humidity, was treated at two levels: 1) 35-45\% relative humidity, and 2) 55-65\% relative humidity. These ranges were selected due to two important reasons: (1) these ranges were able to be strictly controlled with the equipment available; (2) the higher ends of the ranges can approximately represent the environment within occupational gloves.

The exertion trials always began with a 30 second interval of rest, which was immediately followed by 30 second intervals of lateral pinching at $50 \%$ of the participant's maximum strength. This lateral pinching was completed five times per exertion trial. Every trial was precisely five minutes in total duration. In total, 16 experimental trials ( 2 levels of physical exertion $\times 2$ levels of relative humidity $\times 2$ levels of temperature $\times 2$ repetitions) were collected from each individual participant. The experiment was approximately three hours in total duration 
per participant. The trial order was completely randomized for the factors levels of relative humidity and physical exertion. The trial order of the factor levels of temperature were controlled with the first set of eight trials being held to the lower range of $65-75^{\circ} \mathrm{F}$ and the second set of eight trials being held to the higher range of $85-95^{\circ} \mathrm{F}$. A rest period of approximately two to three minutes was provided between each trial to mitigate any effects from fatigue.

\subsection{Experimental Data Collection Procedure}

Upon arriving at the laboratory, the participant was given a thorough explanation of the equipment, data collection procedures, and experimental tasks. The participant was then asked if they suffer or currently suffered from any type of musculoskeletal, degenerative or neurological disorders, and if they had a history of hand or fingertip pain or any current pain.

The participant's signature was then obtained on a consent form approved by the local Institutional Review Board (Appendix B). The participant was then shown how to properly perform a lateral pinch with the pinch meter and asked to perform maximum force exertion trials. The participant was then instructed to apply the force slowly and steadily without jerking motion, until maximum force was reached. Three trials of this maximum force were collected. In the cases where variability was $>10 \%$ between trials, a fourth trial was performed and the average of the best three values was used to determine the pinching strength of the participant.

The participant was then informed of what was $50 \%$ of their pinching strength and were given several opportunities to practice maintaining this level of force. The MyoResearch XP analysis software's interface allowed the participants to view their physical exertion force in real time on a computer screen. After the participant demonstrated proficiency in performing the correct level of force, an initial moisture reading was collected from the participant. Then 
isopropyl alcohol was applied to the hand-finger system to control the baseline moisture readings. The baseline moisture reading was collected 30 seconds after this application. Then the subject was fitted with the blood perfusion probe. This probe was worn by the participant and kept on the same place of the hand for the entire duration of the experiment. After these two initial moisture readings, the participant was ready to begin the experimental trials.

The initial atmospheric conditions of the chamber were set and established, based on the randomized factor levels of the trial. The participant was always given the options to sit or stand during experimental trials to ensure maximum comfort. Depending on the type of trial, the participant then place their hand within the chamber and either exerted force or rested. The participant kept their hand in the chamber continuously until the five minute trial was completely finished. The sequence of events in exertion and non-exertion or rest trials is compared in Figure 4.4 below.

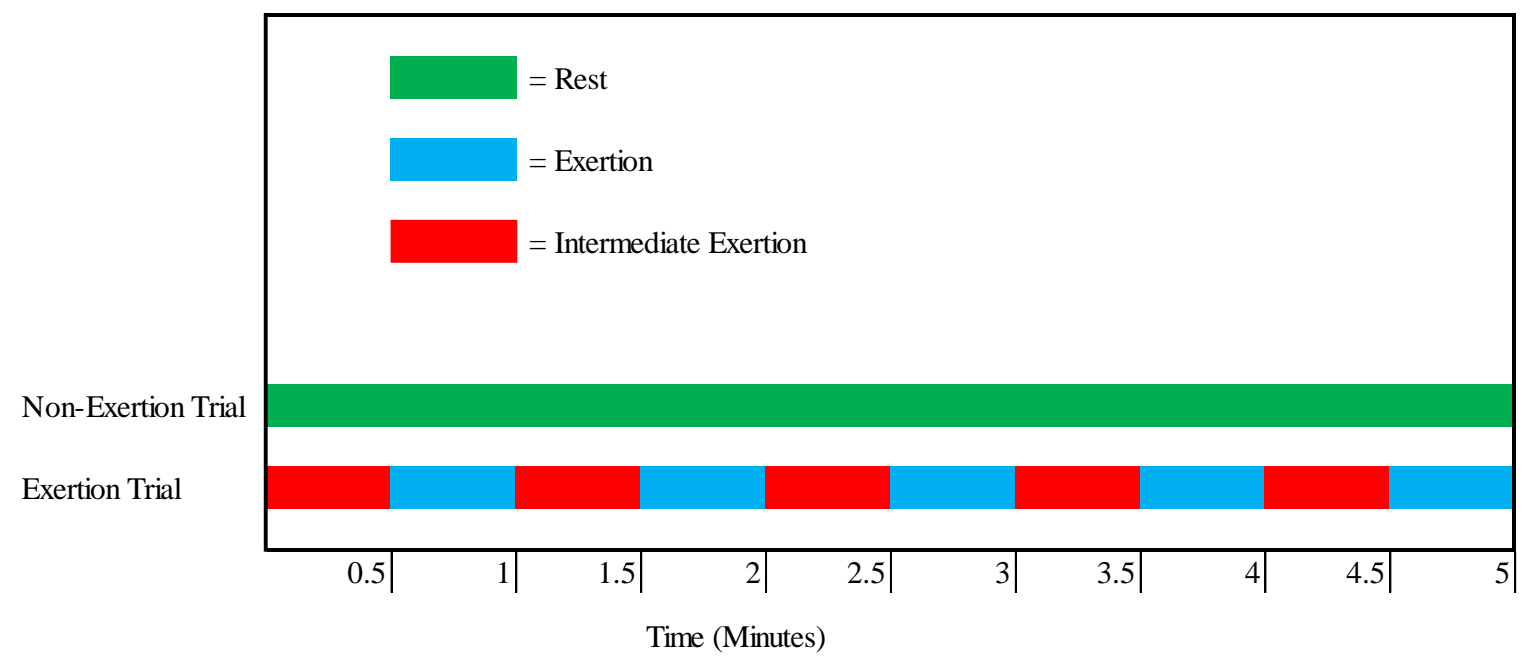

Figure 4.4: Timeline of Exertion and Non-Exertion Trials

Immediately at the end of each trial and as soon as possible, a moisture reading was recorded to reduce air exposure. This methodology was chosen due to its implementation in a previous study (Jones et al., 2008). After each trial, the participant was then asked to numerically 
rate their perceived discomfort on a scale of " 0 " to " 10 ", " 0 " indicating "no discomfort" and "10" indicating "unbearable discomfort" (Appendix B). After the moisture reading, isopropyl alcohol was then applied to the hand-finger system. 30 seconds after application of the isopropyl alcohol, an additional moisture reading was then collected. The participant was then ready for the next trial. These steps were repeated until all 16 trials were completed. A timeline of the experimental trial is provided in Figure 4.5.

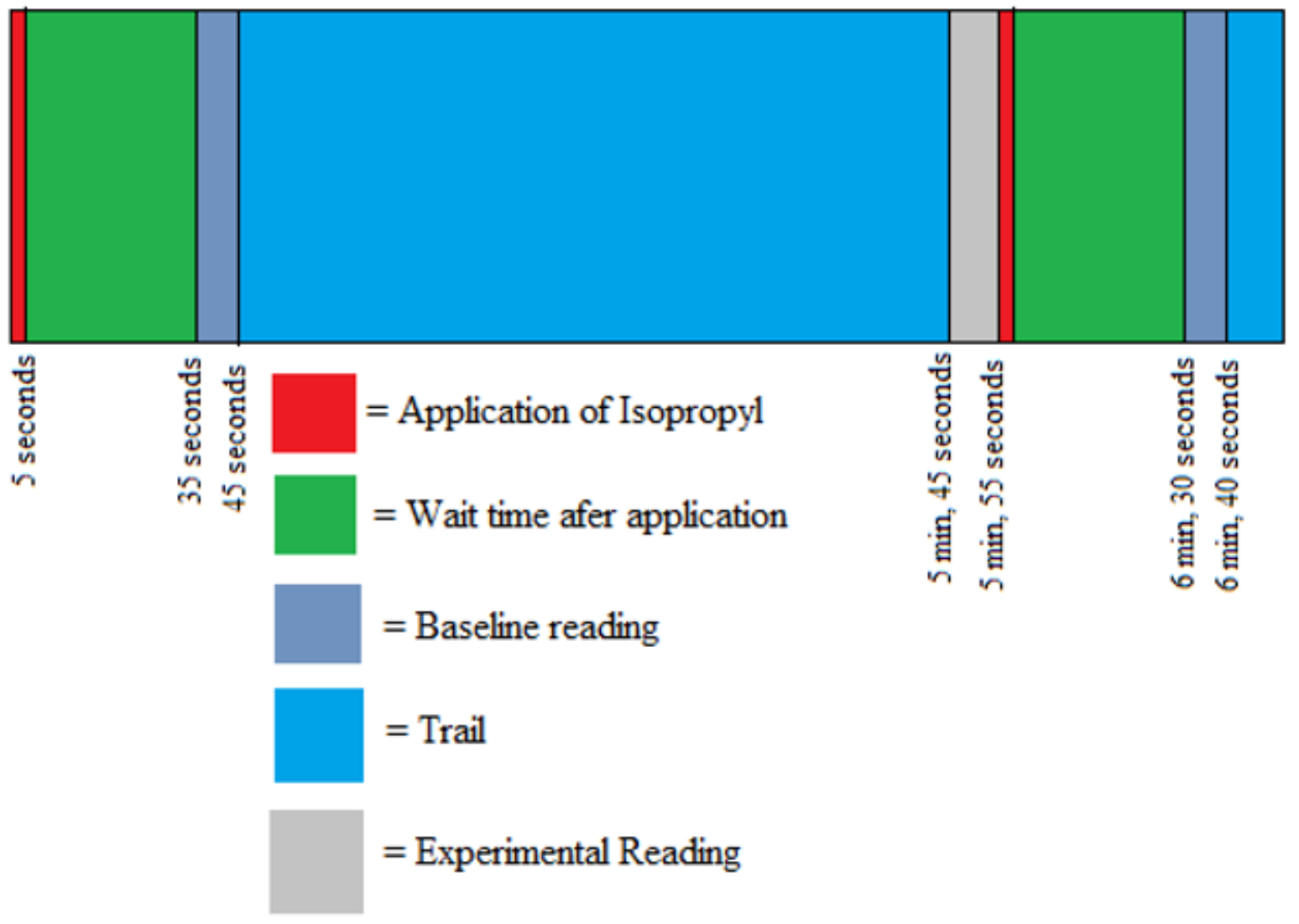

Figure 4.5: Experimental Trial Timeline

\subsection{Data Processing}

Four different sources of data were processed during this study. These data sources were specifically the pinching data, blood perfusion data, skin conductance data, and perceived 
discomfort data. Each of these sources of data had their own processing method that varied in complexity.

The pinching or physical exertion data was collected in three trials. Depending on the variability of the three trials a fourth trial may have been used. The objective of these trials is to determine the maximum voluntary exertion (MVE) or maximum lateral pinching strength of the human subject. This data was used to establish what level of physical exertion will be required of the human subject during exertion trials. The variability and average was calculated by using the pinching data exported from MyoResearch XP analysis software, in the form of a Microsoft Excel file. The Microsoft Excel file was then used for the calculations.

The blood perfusion data was collected in one continuous trial form each participant. Points of interest within the continuous trail, such as start and stop times of experimental trials, were recorded to assist with data processing. The PeriSoft analysis software was then used to export precise segments of data, of the continuous trial, in the form of a Microsoft Excel file. 32 data points per participant were used for the results. The Microsoft Excel file was then used for the calculations of mean and median of the blood perfusion data.

The skin conductance data was collected at 33 instances during the experimental trial of each subject. These instances occurred at the beginning and end of each trial. During each of these collections the skin conductance sensor collected data for an interval of 10 seconds. The data was then exported from MyoResearch XP analysis software, in the form of a Microsoft Excel file. The Microsoft Excel file was then used for the calculations of mean and median of the skin conductance data.

The perceived discomfort was collected at 16 instances during the experiment. These instances occurred at the end of each trial. Each of these collections were recorded directly into a 
Microsoft Excel file. The Microsoft Excel file was then used for calculations of mean and median of the perceived discomfort data.

\subsubsection{Statistical Model}

General Linear ANOVA models were used for statistical analysis of the skin conductance, blood perfusion, and perceived discomfort data. Temperature, relative humidity, and physical exertion factor levels were treated as fixed factors. Human participants were treated as a random blocking factor. Skin conductance data, blood perfusion data, and perceived discomfort data were all treated as dependent variables. The effects of the independent variables on the dependent variables were treated at a significance level of 95\%. Minitab 16 software (Minitab Inc., Pennsylvania, USA) was then used to perform the statistical analysis.

$y R_{i j k l}=\mu+\alpha_{i}+\beta_{j}+\tau_{k}+\gamma_{l}+(\alpha \beta)_{i j}+(\alpha \tau)_{i k}+(\beta \tau)_{j k}+(\alpha \beta \tau)_{i j k}+\epsilon_{i j k l}\left\{\begin{array}{l}i=1, \ldots, a \\ j=1, \ldots, b \\ k=1, \ldots, c \\ l=1, \ldots, n\end{array}\right.$

Where,

$y R$ represents the physiological response of the subject

$\mu$ is the overall mean to all treatments

$\alpha_{i}$ is the effect of presence of physical exertion, then $i=1,2$.

$\beta_{j}$ is the effect of temperature at the ranges of $65^{\circ} \mathrm{F}-75^{\circ} \mathrm{F}$ and $85^{\circ} \mathrm{F}-95^{\circ} \mathrm{F}$ degrees, then $j=1,2$.

$\tau_{k}$ is the effect of relative humidity at the ranges of $35 \%-45 \%$ and $55 \%-65 \%$ then $k=1,2$.

$\gamma_{l}$ is the effect of participants, treated as blocks, $n$ represents the number of participants recruited in the study

$(\alpha \beta)_{i j}$ is the interaction effect of presence of physical exertion and temperature.

$(\alpha \tau)_{i k}$ is the interaction effect of presence of physical exertion and relative humidity. 
$(\beta \tau)_{j k}$ is the interaction effect temperature and relative humidity.

$(\alpha \beta \tau)_{i j k}$ is the interaction effect of the three factors: presence of physical exertion, temperature, and relative humidity.

$\epsilon_{i j k l}$ is a random error term.

In the statistical model, the presence of physical exertion $\left(\alpha_{i}\right)$, temperature range $\left(\beta_{j}\right)$, and relative humidity range $\left(\tau_{k}\right)$ will be treated as fixed factors. It is assumed that each factor and the two-way or three-way interaction factors have no effect on physiological response of the handfinger system. That is:

$$
\begin{gathered}
\sum_{i=1}^{a} \alpha_{i}=0, \quad \sum_{j=1}^{b} \beta_{j}=0, \quad \sum_{k=1}^{c} \tau_{k}=0, \\
\sum_{i=1}^{a} \sum_{j=1}^{b}(\alpha \beta)_{i j}=0, \quad \sum_{i=1}^{a} \sum_{k=1}^{c}(\alpha \tau)_{i k}=0, \quad \sum_{j=1}^{b} \sum_{k=1}^{c}(\beta \tau)_{j k}=0,
\end{gathered}
$$

and

$$
\sum_{i=1}^{a} \sum_{j=1}^{b} \sum_{k=1}^{c}(\alpha \beta \tau)_{i j k}=0 .
$$

Subjects $\left(\gamma_{l}\right)$ are treated as a random factor and it is assumed that it is $\operatorname{NID}\left(0, \sigma_{\gamma}^{2}\right)$ random variable. Random error $\epsilon_{i l}$ and $\epsilon_{i j k l}$ follows NID $\left(0, \sigma^{2}\right)$.

One ANOVA table was provided for this model. Therefore, the appropriate $F$ tests were applied on testing the means of the fixed factor effects are equal, such as

$$
H_{0}: \alpha_{i}=0, \beta_{j}=0, \tau_{k}=0 \text { and }
$$




$$
\begin{gathered}
(\alpha \beta)_{i j}=0,(\alpha \tau)_{i k}=0,(\beta \tau)_{j k}=0, \text { and }(\alpha \beta \tau)_{i j k}=0, \\
H_{1} \text { : at least one } \alpha_{i} \neq 0, \beta_{j} \neq 0 \tau_{k} \neq 0 \text { and } \\
\text { at least one }(\alpha \beta)_{i j} \neq 0,(\alpha \tau)_{i k} \neq 0,(\beta \tau)_{j k} \neq 0 \text {, and }(\alpha \beta \tau)_{i j k} \neq 0,
\end{gathered}
$$

Also the appropriate $F$ tests were applied on testing the variance of the random factor equal to zero, such as $H_{0:} \sigma_{\gamma}{ }^{2}=0$. In this part of study, the Type I error $\alpha=0.05$ and Power of the test (1- $\beta$ ) which equals to 0.90 were chosen for the hypothesis test and sample size determination in 3.2 .

For fixed factors such physical exertion, temperature, and relative humidity, if the null hypothesis is rejected, the factors effects were estimated. For example, $\alpha_{1}$ and/or $\alpha_{2}$ will be estimated to show the physiological response differences if the test shows the presence of physical exertion has an effect.

\subsubsection{Data Normalization and Validity for Statistical Analysis}

The skin conductance data was shown to not follow a normal distribution (Appendix G). To adjust to for this non-normal distribution, skin conductance data was normalized using the following equation:

$$
\text { Normalized Skin Conductance }=\frac{\text { Skin conductance }- \text { Baseline value }}{\text { Maximum skin conductance }}
$$

The normality of the "Normalized Skin Conductance" data was verified using RyanJoiner's normality test (Appendix H). The assumption of equality of variance was also verified using Levene's test (Appendix I). It is important to note that expectedly some of the normalized skin conductance values were of a negative value due to the unique characteristics of each individual. Specifically, in regards to their baseline skin conductance level and their 
physiological response of skin conductance to the exposure of certain atmospheric and physical conditions.

The perceived discomfort data was shown to not follow a normal distribution (Appendix J). To adjust to for this non-normal distribution, perceived discomfort was normalized using the following equation:

$$
\text { Normalized Discomfort }=\frac{\text { Reported discomfort of trial }}{\text { Maximum reported discomfort of participant }}
$$

The normality of the "Normalized Discomfort" data was verified using Ryan-Joiner's normality test (Appendix K). The assumption of equality of variance was also verified using Levene's test (Appendix L).

In difference to the skin conductance and discomfort data, the blood perfusion data did not require normalization. Furthermore, the assumption of equality of variance was also verified using Levene's test (Appendix M; Appendix N). The normality of residuals of the blood perfusion data was also verified (Appendix O; Appendix P). 


\section{Chapter 5: Results}

The results chapter is organized into four sections. In the first section, pinching strength data is presented. In the following three sections physiological responses of perceived discomfort, skin conductance, and blood perfusion are presented.

\subsection{Lateral Pinching Strength Data}

The pinching strength data as a whole can be characterized as having less variation present when compared to the other result sections. The data is presented using the unit of force, newtons $(\mathrm{N})$. The mean and standard deviation of the participants' maximum voluntary exertion (MVE) based on the lateral pinching data was, $41.74 \mathrm{~N}$ and $17.84 \mathrm{~N}$ respectively. This resulting mean is representative of what a large portion of the participants demonstrated as their MVE.

\subsection{Perceived Discomfort Results}

The resulting perceived discomfort data demonstrated several important general trends of interest. First, the perceived discomfort data demonstrated that experimental trials requiring physical exertion consistently resulted in higher values of perceived discomfort than trials requiring no physical exertion. In addition, the perceived discomfort data demonstrated that experimental trials which were held at the higher range of temperature, $85-95^{\circ} \mathrm{F}$, consistently resulted in higher values of perceived discomfort when compared to experimental trials held to the lower temperature range of $65-75^{\circ} \mathrm{F}$.

\begin{tabular}{|l|c|c|c|c|c|c|}
\hline \multicolumn{7}{|c|}{ ANOVA Table of Perceived Discomfort Results } \\
\hline Source & DF & Seg SS & Adj SS & $\begin{array}{c}\text { Adj } \\
\text { MS }\end{array}$ & F & P \\
\hline Sub & 16 & 2.44155 & 2.44717 & 0.15295 & 3.00 & 0.000 \\
\hline Temp & 1 & 2.59714 & 2.58553 & 2.58553 & 50.76 & 0.000 \\
\hline Humidity & 1 & 0.12120 & 0.12157 & 0.12157 & 2.39 & 0.124 \\
\hline Exertion & 1 & 4.37645 & 4.37324 & 4.37324 & 85.86 & 0.000 \\
\hline
\end{tabular}




\begin{tabular}{|c|c|c|c|c|c|c|}
\hline Temp*Humidity & 1 & 0.00396 & 0.00396 & 0.00396 & 0.08 & 0.781 \\
\hline Temp*Exertion & 1 & 0.05453 & 0.05400 & 0.05400 & 1.06 & 0.304 \\
\hline Humidity*Exertion & 1 & 0.02004 & 0.02006 & 0.02006 & 0.39 & 0.531 \\
\hline Temp*Humidity*Exertion & 1 & 0.00012 & 0.00012 & 0.00012 & 0.00 & 0.962 \\
\hline Error & 246 & 12.53004 & 12.53004 & 0.05094 & & \\
\hline Total & 269 & 22.14502 & & & & \\
\hline
\end{tabular}

The main effect of the factor temperature on perceived discomfort was statistically significant $(\mathrm{P}<0.001)$. There was a $32 \%$ increase in perceived discomfort during trials of the higher temperature range of $85-95^{\circ} \mathrm{F}$ when compared to trials of the lower temperature range of $65-75^{\circ} \mathrm{F}$. The main effect of the factor humidity on perceived discomfort was statistically insignificant $(\mathrm{P}<0.124)$. The main effect of the factor physical exertion on perceived discomfort was statistically significant $(\mathrm{P}<0.001)$. There was a $40 \%$ increase in perceived discomfort during trials of exertion when compared to trials of no physical exertion. No interaction effects were statistically significant.

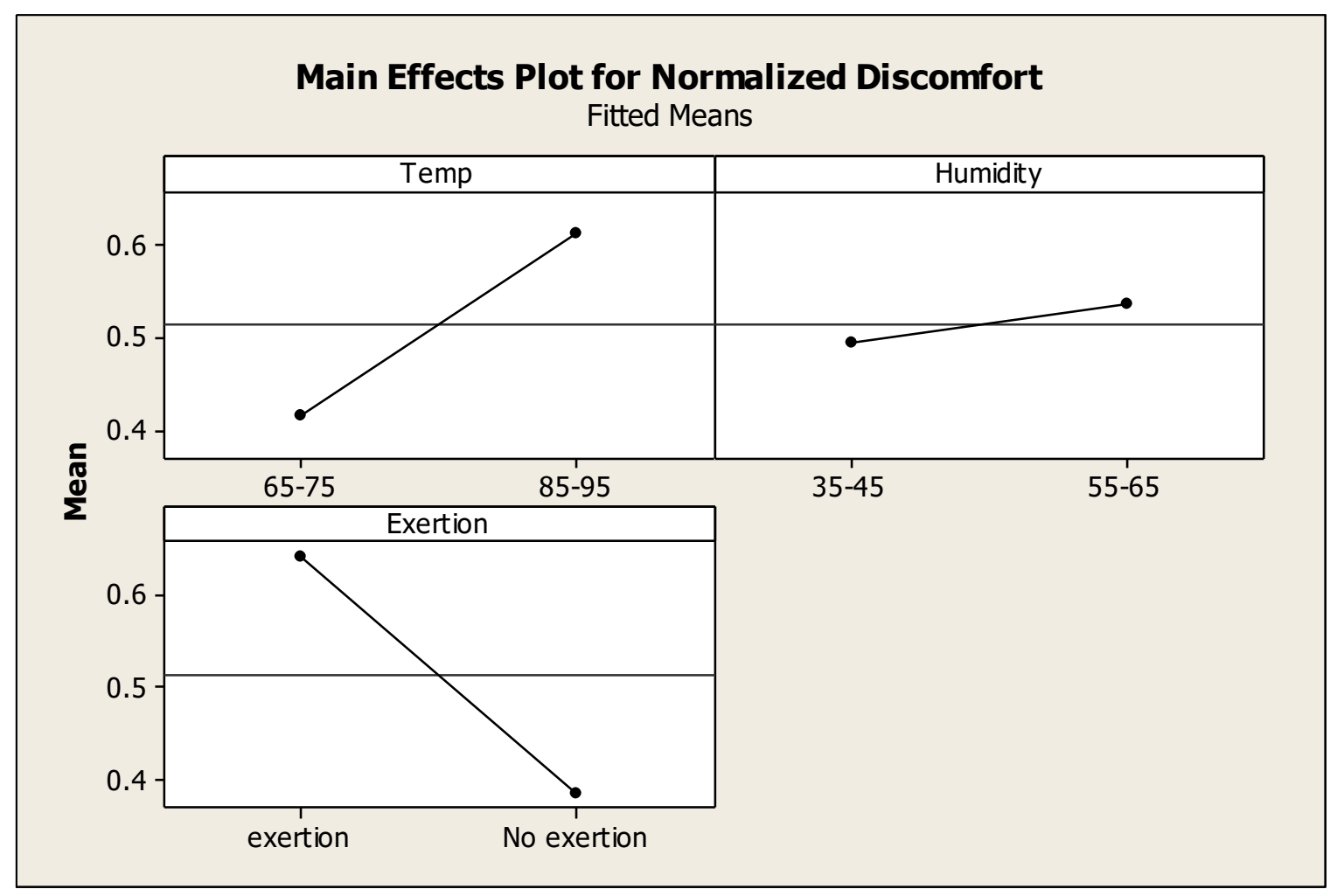




\begin{tabular}{|l|c|c|l|}
\hline \multicolumn{4}{|c|}{ Summary of Variables' Effects and Significance on Perceived Discomfort } \\
\hline Variable & $\mathbf{6 5 - 7 5}^{\circ} \mathbf{F}$ & $\mathbf{8 5 - 9 5}$ F & \\
\hline Temp & & P-Value \\
\cline { 2 - 4 } & $\mathbf{0 . 4 1 5 8 ( 0 . 2 5 4 8 )}$ & $\mathbf{0 . 6 1 1 6}(\mathbf{0 . 2 8 4 4})$ & $\mathbf{0 . 0 0 0}$ \\
\hline Humidity & $35-45 \%$ & $55-65 \%$ & \\
\cline { 2 - 4 } & $\mathbf{0 . 4 9 2 5 ( 0 . 2 8 3 9 )}$ & $\mathbf{0 . 5 3 6 7}(\mathbf{0 . 2 8 9 3})$ & $\mathbf{0 . 1 2 4}$ \\
\hline Exertion & Present & Absent & \\
\cline { 2 - 4 } & $\mathbf{0 . 6 4 1 8}(\mathbf{0 . 2 7 0 9})$ & $\mathbf{0 . 3 8 7 1 ( 0 . 2 4 3 3 )}$ & $\mathbf{0 . 0 0 0}$ \\
\hline
\end{tabular}

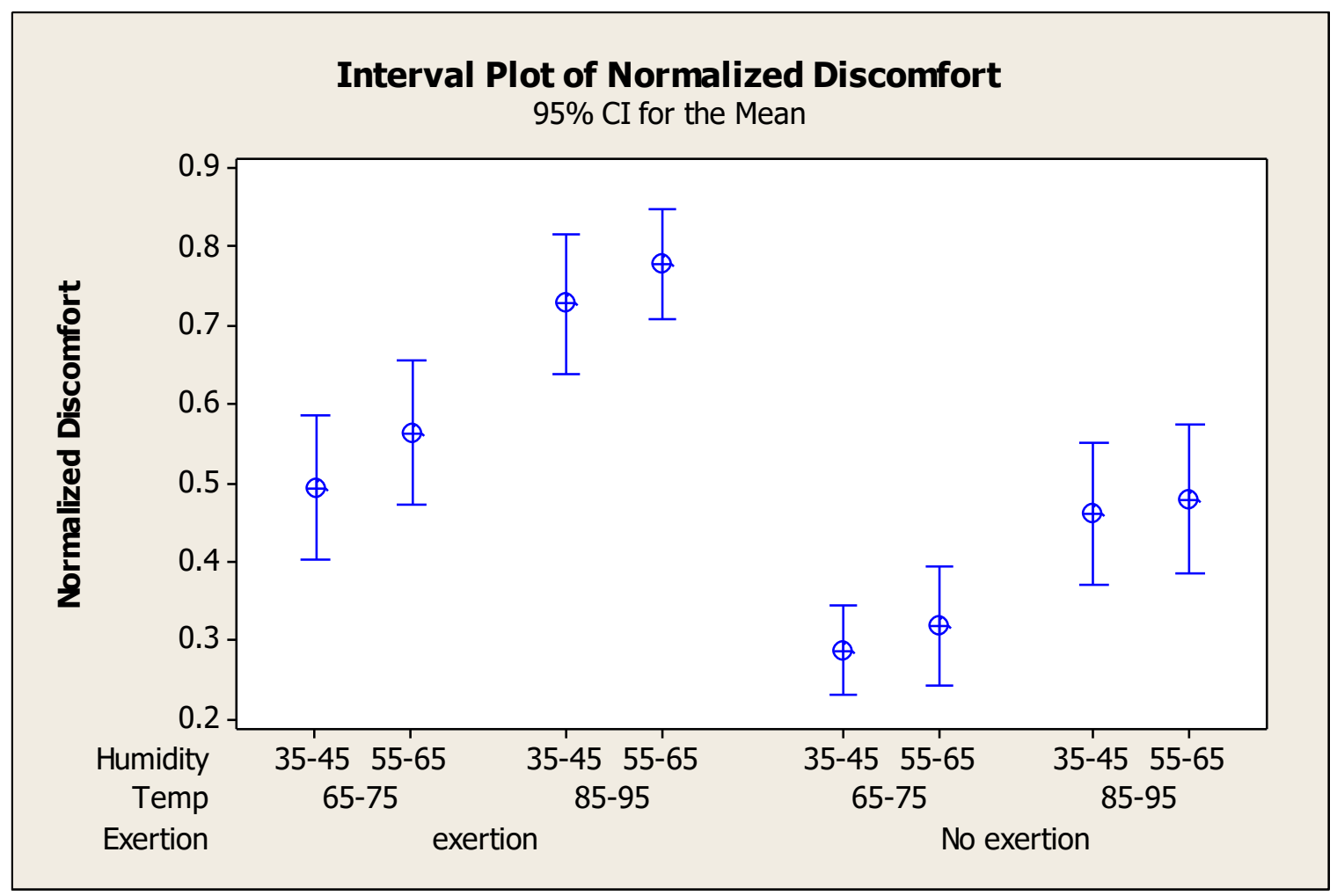




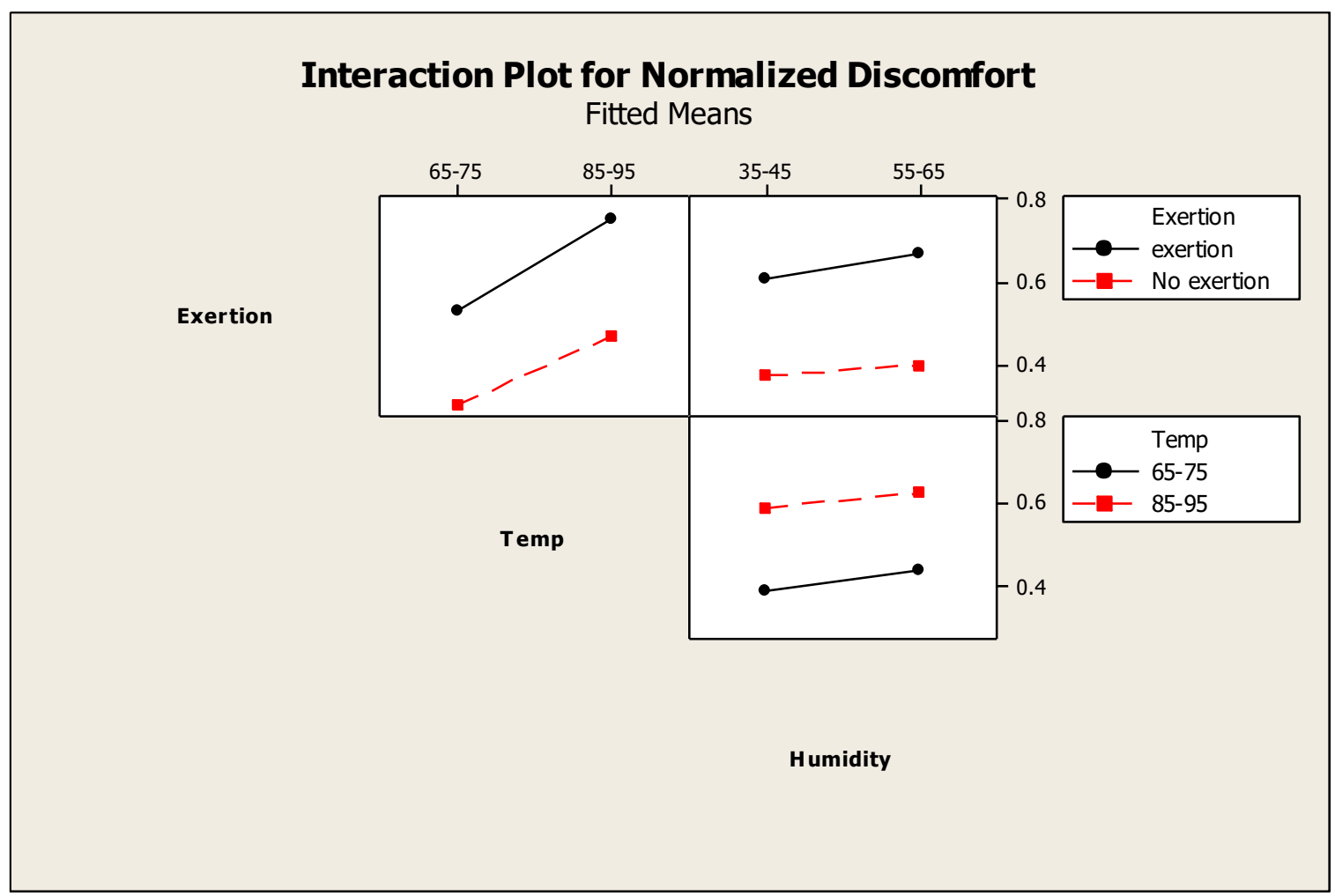

\subsection{Skin Conductance Results}

The resulting skin conductance data demonstrated several important general trends of interest. First, the skin conductance data demonstrated that experimental trials requiring physical exertion consistently resulted in higher values of skin conductance than trials requiring no physical exertion. In addition, the skin conductance data demonstrated that experimental trials which were held at the higher level of temperature, $85-95^{\circ} \mathrm{F}$, consistently resulted in higher values of skin conductance when compared to experimental trials held to the lower temperature range of $65-75^{\circ} \mathrm{F}$. Lastly, the skin conductance data demonstrated that experimental trials which were held at the higher range of relative humidity, 55-65\%, consistently resulted in higher values of skin conductance when compared to experimental trials held to the lower relative humidity range of $35-45 \%$. 


\begin{tabular}{|l|c|c|c|c|c|c|}
\hline \multicolumn{7}{|c|}{ ANOVA Table of Skin Conductance Results } \\
\hline Source & DF & Seg SS & Adj SS & $\begin{array}{c}\text { Adj } \\
\text { MS }\end{array}$ & F & P \\
\hline Sub & 16 & 14.43485 & 14.42854 & 0.90178 & 17.63 & 0.000 \\
\hline Temp & 1 & 0.87113 & 0.86511 & 0.86511 & 16.91 & 0.000 \\
\hline Humidity & 1 & 0.55345 & 0.53309 & 0.53309 & 10.42 & 0.001 \\
\hline Exertion & 1 & 2.98396 & 2.98416 & 2.98416 & 58.33 & 0.000 \\
\hline Temp*Humidity & 1 & 0.00237 & 0.00265 & 0.00265 & 0.05 & 0.820 \\
\hline Temp*Exertion & 1 & 0.00404 & 0.00433 & 0.00433 & 0.08 & 0.771 \\
\hline Humidity*Exertion & 1 & 0.00020 & 0.00020 & 0.00020 & 0.00 & 0.950 \\
\hline Temp*Humidity*Exertion & 1 & 0.07865 & 0.07865 & 0.07865 & 1.54 & 0.216 \\
\hline Error & 246 & 12.58594 & 12.58594 & 0.05116 & & \\
Total & 269 & 31.51459 & \multicolumn{7}{|c|}{} \\
\cline { 1 - 4 }
\end{tabular}

The main effect of the factor temperature on skin conductance was statistically significant $(\mathrm{P}<0.001)$. There was a significant increase in skin conductance during trials of the higher temperature range of $85-95^{\circ} \mathrm{F}$ when compared to trials of the lower temperature range of 65 $75^{\circ} \mathrm{F}$. The main effect of the factor relative humidity on skin conductance was statistically significant $(\mathrm{P}<0.001)$. There was a significant increase in skin conductance during trials of the higher relative humidity range of $55-65 \%$ showed $86.6 \%$ increase when compared to the skin conductance present at the lower relative humidity range of $35-45 \%$. The main effect of the factor physical exertion on skin conductance was statistically significant $(\mathrm{P}<0.001)$. There was a significant increase in skin conductance during trials where physical exertion was present when compared to trials involving no exertion. All interaction effects were statistically insignificant. 




\begin{tabular}{|c|c|c|c|}
\hline \multicolumn{4}{|c|}{ Summary of Variables' Effects and Significance on Skin Conductance } \\
\hline Variable & & & P-Value \\
\hline \multirow[t]{2}{*}{ Temp } & $65-75^{\circ} \mathrm{F}$ & $85-95^{\circ} \mathbf{F}$ & \\
\hline & $-0.1151(0.2977)$ & $0.0005(0.3739)$ & $0.000 *$ \\
\hline \multirow{2}{*}{ Humidity } & $35-45 \%$ & $55 \%-65 \%$ & \\
\hline & $-0.1026(0.3511)$ & $-0.0113(0.3280)$ & 0.001* \\
\hline \multirow[t]{2}{*}{ Exertion } & Present & Absent & \\
\hline & $0.0470(0.2953)$ & $-0.1632(0.3550)$ & $<0.001 *$ \\
\hline
\end{tabular}






\subsection{Blood Perfusion Results}

As stated in Section 4.6 Data Processing, blood perfusion data was collected in one continuous trial for each subject or participant. This allowed the results in Section 5.4.1 to be produced using the statistical model in Section 4.6.1. During the trials of the presence of physical exertion, it was observed that a significant difference in blood perfusion values was occurring. This significant difference was between the 30 second intervals when the human subject was pressing the pinch meter and the 30 second intervals when the human subject had released the pinch meter.

Due to this noticeable difference and the availability of the necessary data, further analysis was performed using the statistical model in Section 4.6.1. It is important to note, all of the data showing the significant difference originates from physical exertion trials only. Furthermore, during this additional analysis, the factor levels of physical exertion were modified from "Exertion" and "No Exertion" to "Exertion" and "Intermediate Exertion". The physical exertion factor level of "Exertion" equates to blood perfusion values obtained during the 30 second intervals in which the human subject was pressing the pinch meter. The physical exertion factor level of "Intermediate Exertion" equates to blood perfusion values obtained during the 30 second intervals in which the human subject has released the pinch meter. Each physical exertion trial would result in 150 seconds of "Intermediate Exertion" data and 150 second of "Exertion" data. The results of this additional analysis are within Section 5.4.2.

\subsubsection{Blood Perfusion Results}

The resulting blood perfusion data did not demonstrated many general trends of interest. The only consistent trend was the effect the presence of physical exertion had on the blood perfusion data. Specifically, experimental trials requiring the presence of physical exertion 
consistently resulted in higher values of blood perfusion when compared to experimental trials requiring that physical demand be absent.

\begin{tabular}{|l|c|c|c|c|c|c|}
\hline \multicolumn{7}{|c|}{ ANOVA Table of Blood Perfusion Results } \\
\hline Source & DF & Seg SS & Adj SS & Adj MS & F & P \\
\hline Sub & 16 & 111391.6 & 111391.6 & 6962.0 & 14.93 & 0.000 \\
\hline Exertion & 1 & 15744.6 & 15744.6 & 15744.6 & 33.77 & 0.000 \\
\hline Temp & 1 & 108.1 & 108.1 & 108.1 & 0.23 & 0.631 \\
\hline Humidity & 1 & 0.0 & 0.0 & 0.0 & 0.00 & 0.995 \\
\hline Temp*Exertion & 1 & 0.1 & 0.1 & 0.1 & 0.00 & 0.987 \\
\hline Humidity*Exertion & 1 & 221.5 & 221.5 & 221.5 & 0.47 & 0.492 \\
\hline Temp*Humidity & 1 & 5.5 & 5.5 & 5.5 & 0.01 & 0.913 \\
\hline Temp*Humidity*Exertion & 1 & 5.3 & 5.3 & 5.3 & 0.01 & 0.915 \\
\hline Error & 112 & 52221.9 & 52221.9 & 466.3 & & \\
\hline Total & 135 & 179698.6 & & & & \\
\hline
\end{tabular}

The main effect of the factor temperature on blood perfusion was statistically insignificant $(\mathrm{P}<0.631)$. The main effect of the factor relative humidity on blood perfusion was statistically insignificant $(\mathrm{P}<0.995)$. The main effect of the factor physical exertion on blood perfusion was statistically significant $(\mathrm{P}<0.000)$. There was a significant increase in blood perfusion during trials of where physical exertion was present when compared to trials involving no exertion. All interaction effects were statistically insignificant. 


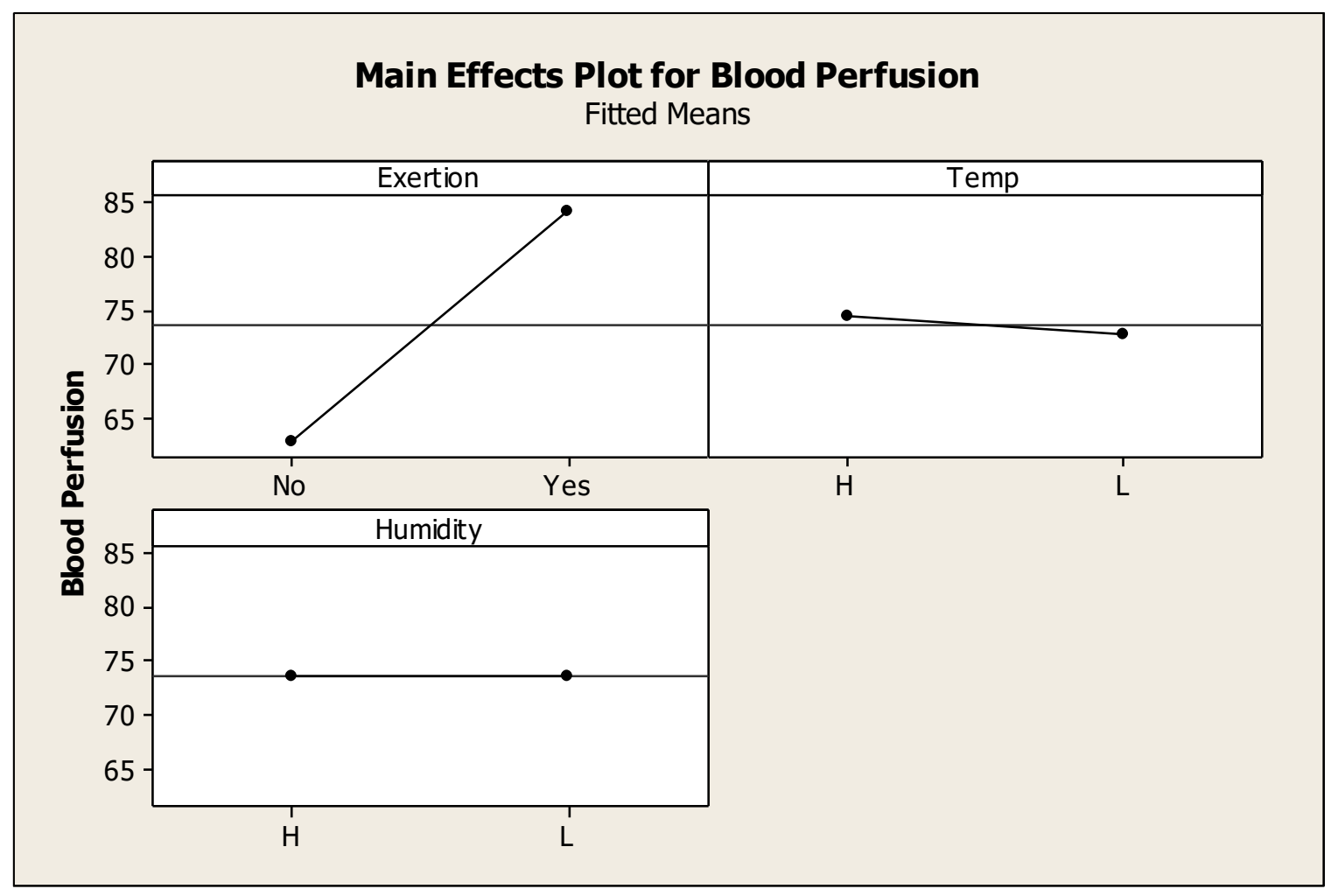

\begin{tabular}{|c|c|c|c|}
\hline \multicolumn{4}{|c|}{ Summary of Variables' Effects and Significance on Blood Perfusion } \\
\hline Variable & & & P-Value \\
\hline \multirow[t]{2}{*}{ Temp } & 65-75 ${ }^{\circ} \mathrm{F}$ & $85-95^{\circ} \mathbf{F}$ & \\
\hline & $80.61(43.58)$ & $84.11(43.02)$ & 0.631 \\
\hline \multirow[t]{2}{*}{ Humidity } & $35-45 \%$ & $55 \%-65 \%$ & \\
\hline & $82.29(44.67)$ & $82.43(41.96)$ & 0.995 \\
\hline \multirow[t]{2}{*}{ Exertion } & Exertion & No Exertion & \\
\hline & $94.77(38.98)$ & $69.95(43.87)$ & $0.000 *$ \\
\hline
\end{tabular}



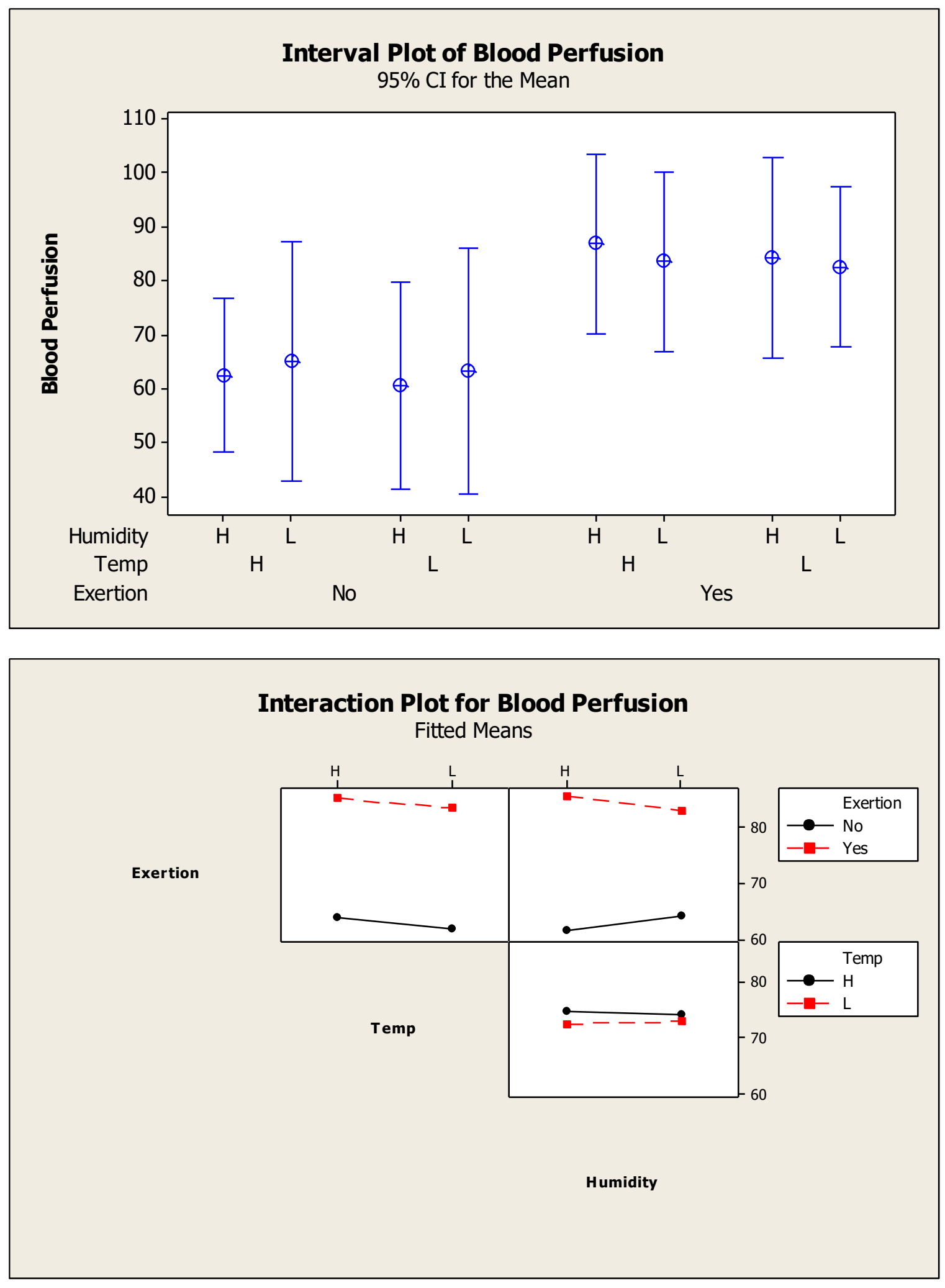


\subsubsection{Blood Perfusion Results of Modified Exertion Trials}

The results of additional analysis of the blood perfusion data did not demonstrated many general trends of interest. The only consistent trend was the effect of the participant releasing the pinch meter, or the period of time of the experimental trial representing "Intermediate Exertion", had on the blood perfusion data. Specifically, the periods of time representing "Intermediate Exertion" consistently resulted in higher values of blood perfusion when compared to the periods of time representing "Exertion".

\begin{tabular}{|c|c|c|c|c|c|c|}
\hline \multicolumn{7}{|c|}{ ANOVA Table of Blood Perfusion Results (Intermediate Exertion V.S. Exertion) } \\
\hline Source & DF & Seg SS & Adj SS & Adj MS & $\mathbf{F}$ & $\mathbf{P}$ \\
\hline Sub & 16 & 99617.8 & 99617.8 & 6226.1 & 7.59 & 0.000 \\
\hline Exertion & 1 & 7390.7 & 7390.7 & 7390.7 & 9.01 & 0.003 \\
\hline Temp & 1 & 0.6 & 0.6 & 0.6 & 0.00 & 0.978 \\
\hline Humidity & 1 & 198.7 & 198.7 & 198.7 & 0.24 & 0.624 \\
\hline Temp*Exertion & 1 & 215.2 & 215.2 & 215.2 & 0.26 & 0.610 \\
\hline Humidity*Exertion & 1 & 604.1 & 604.1 & 604.1 & 0.74 & 0.393 \\
\hline Temp*Humidity & 1 & 0.1 & 0.1 & 0.1 & 0.00 & 0.990 \\
\hline Temp*Humidity*Exertion & 1 & 15.7 & 15.7 & 15.7 & 0.02 & 0.890 \\
\hline Error & 112 & 91873.2 & 91873.2 & 820.3 & & \\
\hline Total & 135 & 199916.1 & & & & \\
\hline
\end{tabular}

The main effect of the factor temperature on blood perfusion was statistically insignificant $(\mathrm{P}<0.978)$. The main effect of the factor relative humidity on blood perfusion was statistically insignificant $(\mathrm{P}<0.624)$. The main effect of the factor physical exertion on blood perfusion was statistically significant $(\mathrm{P}<0.003)$. There was a significant decrease in blood perfusion during exertion trials when physical exertion was occurring compared to when intermediate exertion was occurring. All interaction effects were statistically insignificant. 


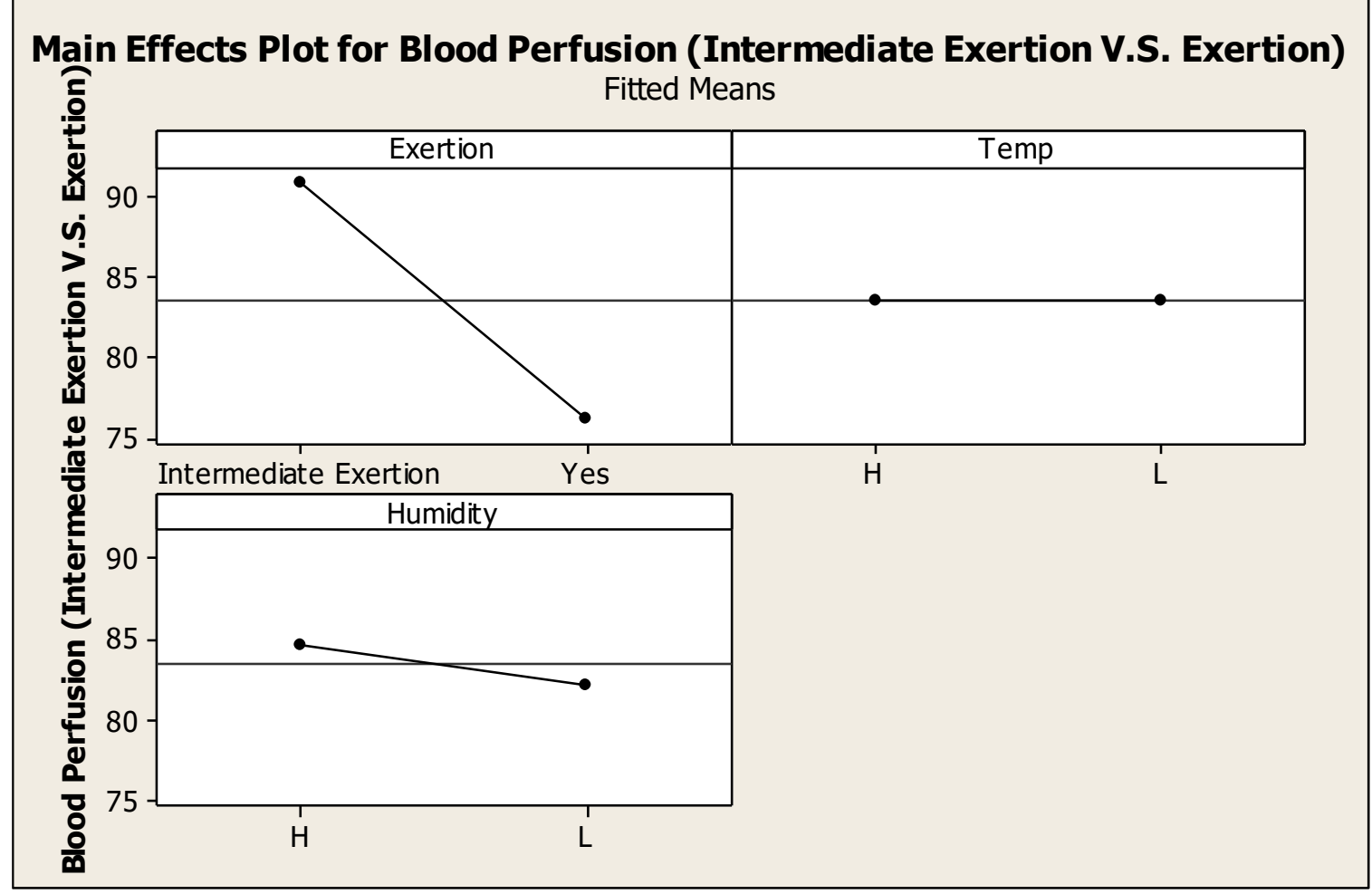

\begin{tabular}{|l|c|c|l|}
\hline \multicolumn{4}{|c|}{ Summary of Variables' Effects and Significance on Blood Perfusion (Intermediate } \\
Exertion V.S. Exertion)
\end{tabular}






\section{Chapter 6: Discussion and Conclusions}

This study provides baseline physiological response data of the hand-finger system when subjected to controlled conditions of temperature, relative humidity, and physical exertions. Review of this physiological response data can provide insight into how and to what degree certain factors impact the worker's physiological response to the occupational environment and demand. Specifically, this data can provide important insight into workers who use gloves for extended periods of time in warm environments that also require repetitive physical exertions. The environment within the glove or microenvironment is expected to have the conditions of elevated temperature (Bishop, Gu, and Clapp, 2000).

The physiological response of perceived hand and finger discomfort has been identified as a contributor to inefficiency and a precursor to certain injuries. This study provides some insight into these specific issues due to collecting perceived discomfort data from human subjects exposed to controlled occupational factors of microenvironment and physical demand. It has been previously theorized that temperature and physical exertion are directly related to perceived discomfort. This study's results of perceived discomfort data align with this idea. This study's results of perceived discomfort data also agree with the idea that higher temperature and an increase in physical exertion further pronounces this physical response of discomfort. This study found that the higher range of temperature and the presence of physical exertion resulted in very similar main effects on perceived discomfort. This study also found that the lower range of temperature and the absence of exertion or physical demand resulted in very similar main effects on perceived discomfort. This demonstrates that both higher temperature conditions and physical demand are significant and suggests both these conditions have a similar impact on the physiological response of perceived discomfort. 
The insignificance of relative humidity in regards to perceived discomfort is in opposition to the findings of several previous studies (Gnaneswaran, Mudhunuri, and Bishu, 2008; Jones et al., 2008). However, these conflicting results may be due to several possibilities. The prior studies stated a reduction in both relative humidity and skin conductance resulted in a reduction in discomfort (Jones et al., 2008; Gnaneswaran, Mudhunuri, and Bishu, 2008). It is possible that the reduction of skin conductance is a necessary condition for a reduction in perceived discomfort. Furthermore, it would then be possible that the necessary reduction in skin conductance may not have been realized during this study.

Another possible cause of the conflicting result of relative humidity being insignificant is that the ranges tested where not sufficiently different or extreme (Jones et al., 2008). Specifically, much of the literature identified conditions where relative humidity is near $100 \%$ and the physiological response of skin conductance or skin moisture is impeded drastically (Bernard, 1999; Jones et al., 2008;Tanka, Nakama, and Katonchi 2014; Charvat et al., 2015). An increase in the controlled higher range of relative humidity may result in the factor of relative humidity becoming significant in regards to the physiological response of perceived discomfort.

The physiological response of skin conductance has been identified as a contributor to inefficiency and a precursor to injury as well. These injuries include but are not limited to Onycholysis, skin irritation, discomfort, and lead to the development of skin allergies (Behroozy, Ali, and Keegel, 2014; Schäfer et al., 2002; Tsai, Tsen-Fang, and Maibach, 1999; Lynde, 2008; Jones et al., 2008; Tanaka, Nakamura, and Katafuchi, 2014; Charvat et al., 2015; Strauss, 2004; Amick et al., 2016). This study provides some insight into these specific issues due to collecting skin conductance data from human subjects exposed to controlled occupational factors of microenvironment and physical demand. This study agrees with previous studies with its 
findings that physical exertion, temperature, and relative humidity are significant in regards to skin conductance (Reid and McFarland, 2015; Charvat et al., 2015; Jones et al., 2008; Tsai, Tsen-Fang, and Maibach, 1999; Lynde, 2008). The microenvironment conditions of both higher relative humidity range and higher temperature range resulted in an increase in skin conductance. The presence of physical exertion also resulted in an increase in skin conductance. This relationship and understanding is important in regards to microclimates within occupational gloves.

Assuming the microclimate is increasing in temperature, as it often does, our study shows that this will result in an increase in skin sweat (Bishop, Gu, and Clapp, 2000). This will result in the microclimate increasing in overall humidity. This higher humidity can disrupt the effectiveness of the cooling attribute of skin conductance and result in a further increase in temperature. Due to the unique characteristics of the occupational glove's microclimate, the normal physiological responses to high temperature are impaired and can result in injury. This is important when you consider other injuries that have high temperature as a causative factor such as cumulative trauma disorders (Ross, 1994). This understanding further demonstrates the importance of the selection of occupational gloves while considering factors other than safety such as insulation or water permeability of the occupational gloves (Bernard, 1999). This understanding also further validates research advancing the ventilation capabilities of the EVA gloves with the hopes of maintaining and controlling temperature and relative humidity within the microclimate (Jones et al., 2008). If these conditions are controlled properly this study's research suggested it could result in a reduction in risk of injury.

The physiological response of blood perfusion has been identified as a relevant factor to some hand and finger injuries including Onycholysis. This study provides some insight into these 
specific issues due to collecting blood perfusion data from human subjects exposed to controlled occupational factors of microenvironment and physical demand. This study shows that the only significant occupational factor was physical demand. The findings of these studies are unique when you review the results of intermediate exertion. In this study intermediate exertion is a form of resting or lack of exertion. However, the physiological response of blood perfusion during these intervals of resting or intermediate exertion is significantly higher than trials involving no exertion. This shows that the effect of exertion has a lasting impact on the physiological response of blood perfusion. Furthermore, this shows that occupational tasks involving repetitive exertion may have lasting impact on blood perfusion. This provides support that the physiological response of blood perfusion may be an important factor of repetitive hand injuries.

\subsection{Limitations and Future Work}

The number of subjects and the population of the subjects were both limitations of this study. The study consisted of 17 human subjects who were college age students. These individuals had limited experience with occupational gloves and do not precisely match the characteristics of the occupational population. In future studies workers, who have experience using occupational gloves should be recruited for data collection.

Another important limitation of the study was the factor of temperature not being randomized. Equipment limitations were the reasoning of why this factor was not randomized. In future studies, the factor of temperature should be randomized. The ranges of temperature and relative humidity were also chosen due to equipment limitations. In future studies, the ranges of temperature and relative humidity should be diversified and in more extreme states. An example of an extreme state would be a relative humidity range closer to $100 \%$. 
This study's physical exertion was limited to lateral pinching. Although this allowed additional control and consistency, this attribute of the study is a limitation as well. Physical exertions involving hand and gloves injuries include exertions other than lateral pinching. Future studies should utilize additional physical exertion movements that are common for occupational tasks. The study also only focused on the primary hand. Future studies should expand to both hands. These studies could provide insight into whether the physiological responses of the primary and secondary hand differ.

\subsection{Occupational Application}

Occupational gloves and physical exertions are very common characteristics of many different occupational positions. In addition, it has been identified that the occupational glove's microenvironment is often associated with conditions of high temperature and high relative humidity. These results could be helpful to both managers and ergonomists when selecting or suggesting occupational gloves for workers while minimizing risk of injury. For example, when selecting occupational safety gloves for workers within a metal casting environment, gloves that provided both sufficient protection and heat loss would be preferable in terms to gloves only providing sufficient protection.

In addition, these results could be helpful in the design of occupational safety gloves. Specifically the effects atmospheric conditions have on the hand-finger system can be accounted for in the design and preventative measures may be implemented. For example, when designing occupational safety gloves for workers repairing a roof in a high temperature environment ensuring proper heat loss would be critical to preventing discomfort. This could be accounted for in the design by changing the material and/or minimizing the area covered by glove material. 
Furthermore, these results could be used as the basis for safety organizations to explore and set additional hand safety standards. Specifically, standards that review occupational conditions, the type of glove worn, and the expected effect on the worker's hands. For example, a standard could state appropriate work rest cycle for occupations, which require sustained physical exertion using heavy industrial safety gloves. Another example would be standards on heat loss values for the gloves used in extreme temperature environment.

\subsection{Conclusions}

The findings of this study demonstrate that the microclimate of occupational gloves have a significant impact on the physiological responses of the hand-finger system. In addition, these findings demonstrate that the physiological responses can vary greatly depending on the presence of physical exertion, the conditions of the microclimate, and the individual themselves. This study also demonstrated the impact physical exertion can have on blood perfusion. Specifically this study found that physical exertion can have a lasting and cumulative effect on blood perfusion. This study found that in order to reduce perceived discomfort, temperature and physical exertion should be reduced. In addition, in order to reduce skin conductance relative humidity, temperature, and physical exertion should be reduced. 


\section{References}

1. Amick, Ryan Z., Christopher R. Reid, Linh Q. Vu, Dan Nguyen, Robert Sweet, Shane McFarland, and Sudhakar Rajulu. "Preliminary Assessment of Ergonomic Injury Risk Factors in the Extravehicular Mobility Unit Spacesuit Glove." (2016).

2. Ansari, Rafat R., Jeffrey A. Jones, Luca Pollonini, Mikael Rodriguez, Roedolph Opperman, and Jason Hochstein. "A non-invasive miniaturized-wireless laser-Doppler fiber optic sensor for understanding distal fingertip injuries in astronauts." In SPIE BiOS: Biomedical Optics, pp. 718609-718609. International Society for Optics and Photonics, 2009.

3. Charvat, Chacqueline M., Jason Norcross, Christopher R. Reid, and Shane M. McFarland. "Spacesuit Glove-Induced Hand Trauma and Analysis of Potentially Related Risk Variables." (2015).

4. Chato, John C., and Bruce A. Hertig. "Regulation of thermal sweating in EVA space suits." (1969).

5. Farran, Laura, A. Roland Ennos, and Stephen J. Eichhorn. "The effect of humidity on the fracture properties of human fingernails." Journal of Experimental Biology 211, no. 23 (2008): 3677-3681.

6. Jones, J. A., C. M. Mathers, J. Dewitt, R. A. Scheuring, D. Hagan, R. B. Hoffman, S. Strauss et al. "Inflight and NBL training musculoskeletal and extremity injuries: mechanisms and potential countermeasures." In Available at the following Website: http://www. dsls. usra. edu/meetings/hrp2007/pdf/SmartMed/3130Jones. pdf. $2007 .$.

7. Jones, J. A., R. B. Hoffman, D. A. Buckland, C. M. Harvey, C. K. Bowen, C. E. Hudy, S. Strauss, J. Novak, and M. L. Gernhardt. "The use of an extended ventilation tube as a 
countermeasure for EVA-associated upper extremity medical issues." Acta Astronautica 63, no. 7 (2008): 763-768.

8. Opperman, Roedolph A., James Waldie, Alan Natapoff, Dava J. Newman, and Jeffrey A. Jones. "Probability of spacesuit-induced fingernail trauma is associated with hand circumference." Aviation, space, and environmental medicine 81, no. 10 (2010): 907-913.

9. Reid, Christopher R., Shane M. McFarland, Jason R. Norcross, and Sudhakar Rajulu. "The Potential of Wearable Sensor Technology for EVA Glove Ergonomic Evaluation." (2014).

10. Reid, Christopher R., and Shane M. McFarland. "Feasibility Assessment of an EVA Glove Sensing Platform to Evaluate Potential Hand Injury Risk Factors." (2015).

11. Scheuring, R., J. R. Davis, J. M. Duncan, J. D. Polk, J. A. Jones, and D. B. Gillis. "Recommendations for Exploration Space Medicine from the Apollo Medical Operations Project." (2007).

12. Scheuring, Richard A., Charles H. Mathers, Jeffrey A. Jones, and Mary L. Wear. "Musculoskeletal injuries and minor trauma in space: incidence and injury mechanisms in US astronauts." Aviation, space, and environmental medicine 80, no. 2 (2009): 117-124.

13. Strauss, Samuel. "Extravehicular mobility unit training suit symptom study report." (2004).

14. Strauss, Samuel, Ralph L. Krog, and Alan H. Feiveson. "Extravehicular mobility unit training and astronaut injuries." Aviation, space, and environmental medicine 76, no. 5 (2005): 469-474. 
15. Tanaka, Kunihiko, Koji Nakamura, and Tetsuro Katafuchi. "Self-perspiration garment for extravehicular activity improves skin cooling effects without raising humidity." Acta Astronautica 104, no. 1 (2014): 260-265.

16. Viegas, Steven F., David Williams, Jeffrey Jones, Samuel Strauss, and Jonathan Clark. "Physical demands and injuries to the upper extremity associated with the space program." The Journal of hand surgery 29, no. 3 (2004): 359-366.

17. Packham, Chris. "Alleged allergenicity of latex gloves." Annals of Occupational Hygiene 50, no. 7 (2006): 749-749.

18. Allmers, Henning, Jörg Schmengler, and Swen Malte John. "Decreasing incidence of occupational contact urticaria caused by natural rubber latex allergy in German health care workers." Journal of allergy and clinical immunology 114, no. 2 (2004): 347-351.

19. Turjanmaa, Kristiina, Mikko Kanto, Hannu Kautiainen, Timo Reunala, and Timo Palosuo. "Long-term outcome of 160 adult patients with natural rubber latex allergy." Journal of allergy and clinical immunology 110, no. 2 (2002): S70-S74.

20. Sawyer, J. O., and Allan Bennett. "Comparing the level of dexterity offered by latex and nitrile SafeSkin gloves." Annals of Occupational Hygiene 50, no. 3 (2006): 289-296.

21. Turjanmaa, Kristiina. "Incidence of immediate allergy to latex gloves in hospital personnel." Contact dermatitis 17, no. 5 (1987): 270-275.

22. Turjanmaa K, Laurila K, Mäkinen-Kiljunen S, Reunala T. Rubber contact urticaria: allergenic properties of 19 brands of latex gloves. Contact Dermatitis 1988;19:362-7.

23. Turjanmaa K. Latex glove contact urticaria [thesis]. University of Tampere. Acta Universitatis Tamperensis 1988;254:1-86 
24. Taylor, James S., and Podjanee Praditsuwan. "Latex allergy: review of 44 cases including outcome and frequent association with allergic hand eczema." Archives of Dermatology 132, no. 3 (1996): 265-271.

25. Poole, C. J. M. "Protective Gloves for Occupational Use." Occupational Medicine 57, no. 5 (2007): 386-386.

26. Alessio, L., A. Baruffini, G. Biscaldi, A. M. Cirla, G. Cortona, M. Crippa, G. Franco, G. Marcer, G. Moscato, and F. Toffoletto. "Allergic and Irritant Glove-related Diseases in Health Care Workers and Their Prevention: Document of the Italian Society of Preventive Medicine for Health Care Workers." International journal of occupational and environmental health(2013).

27. Willms, Kirsten, Richard Wells, and Heather Carnahan. "Glove Attributes and Their Contribution to Force Decrement and Increased Effort in Power Grip at Maximal and Submaximal Levels." Human Factors: The Journal of the Human Factors and Ergonomics Society (2010).

28. Chen, Wen-Lin, Yuh-Chuan Shih, and Chia-Fen Chi. "Hand and finger dexterity as a function of skin temperature, EMG, and ambient condition."Human Factors: The Journal of the Human Factors and Ergonomics Society(2010).

29. Bradley, James V. "Effect of gloves on control operation time." Human Factors: The Journal of the Human Factors and Ergonomics Society 11, no. 1 (1969): 13-20.

30. Bellingar, Teresa A., and Ann C. Slocum. "Effect of protective gloves on hand movement: an exploratory study." Applied Ergonomics 24, no. 4 (1993): 244-250.

31. Bensel, Carolyn K. "The effects of various thicknesses of chemical protective gloves on manual dexterity." Ergonomics 36, no. 6 (1993): 687-696. 
32. Bishu, Ram R., and Glenn Klute. "The effects of extra vehicular activity (EVA) gloves on human performance." International Journal of Industrial Ergonomics 16, no. 3 (1995): 165-174.

33. Shih, R. H., E. M. Vasarhelyi, A. Dubrowski, and H. Carnahan. "The effects of latex gloves on the kinetics of grasping." International Journal of Industrial Ergonomics 28, no. 5 (2001): 265-273.

34. Dianat, Iman, Christine M. Haslegrave, and Alex W. Stedmon. "Short and longer duration effects of protective gloves on hand performance capabilities and subjective assessments in a screw-driving task." Ergonomics 53, no. 12 (2010): 1468-1483.

35. Dianat, Iman, Christine M. Haslegrave, and Alex W. Stedmon. "Using pliers in assembly work: Short and long task duration effects of gloves on hand performance capabilities and subjective assessments of discomfort and ease of tool manipulation." Applied ergonomics 43, no. 2 (2012): 413-423.

36. Thompson, Shelby, Kritina Holden, Scott England, and Elizabeth Benson. "The effect of pressurized space gloves on operability of cursor controls, mobility, and strength." In Proceedings of the Human Factors and Ergonomics Society Annual Meeting, vol. 55, no. 1, pp. 1587-1591. SAGE Publications, 2011.

37. Behroozy, Ali, and Tessa G. Keegel. "Wet-work exposure: a main risk factor for occupational hand dermatitis." Safety and health at work 5, no. 4 (2014): 175-180.

38. Nilsson, Eskil, Bo Mikaelsson, and Sture Andersson. "Atopy, occupation and domestic work as risk factors for hand eczema in hospital workers."Contact Dermatitis 13, no. 4 (1985): 216-223. 
39. Schäfer, P., C. Bewick-Sonntag, M. G. Capri, and E. Berardesca. "Physiological changes in skin barrier function in relation to occlusion level, exposure time and climatic conditions." Skin Pharmacology and Physiology15, no. 1 (2001): 7-19.

40. Cutting, K., and Richard J. White. "Maceration of the skin and wound bed I: its nature and causes." Journal of wound care 11, no. 7 (2002): 275-278.

41. Stender, I. M., C. Blichmann, and J. Serup. "Effects of oil and water baths on the hydration state of the epidermis." Clinical and experimental dermatology 15, no. 3 (1990): 206-209.

42. Tsai, Tsen-Fang, and Howard I. Maibach. "How irritant is water? An overview." Contact dermatitis 41, no. 6 (1999): 311-314.

43. Lynde, Charles. "Moisturizers for the treatment of inflammatory skin conditions." Journal of drugs in dermatology: JDD 7, no. 11 (2008): 1038-1043.

44. Trapé, Marcia, Paula Schenck, and Andrew Warren. "Latex gloves use and symptoms in health care workers 1 year after implementation of a policy restricting the use of powdered gloves." American journal of infection control28, no. 5 (2000): 352-358.

45. Rose, Rebecca F., Paul Lyons, Helen Horne, and S. Mark Wilkinson. "A review of the materials and allergens in protective gloves." Contact Dermatitis 61, no. 3 (2009): 129137.

46. Laine, Tero, and Pertti Aarnio. "How often does glove perforation occur in surgery? Comparison between single gloves and a double-gloving system."The American Journal of Surgery 181, no. 6 (2001): 564-566.

47. Jensen, S. L. "[Defects in the surgical glove barrier. Single or double gloves]." Ugeskrift for laeger 165, no. 10 (2003): 1016-1019. 
48. Siddharth Gosavi, Sulekha, Siddharth Yuvraj Gosavi, and Rama Krishna Alla. "Local and Systemic Effects of Unpolymerised Monomers." Dental Research Journal 7, no. 2 (2011).

49. Fakhouri, J., R. Sarkis, M. Chababi-Atallah, and G. Aftimos. "Toxic effects of methyl methacrylate monomer on male genital tissues. In vitro study in rats." Le Journal medical libanais. The Lebanese medical journal 56, no. 1 (2007): 22-26.

50. Bhola, Rahul, Shaily M. Bhola, Hongjun Liang, and Brajendra Mishra. "Biocompatible denture polymers-a review." Trends in Biomaterials and Artificial Organ 23, no. 3 (2010): 129-36.

51. Harnoss, J. C., A. Kramer, C. D. Heidecke, and O. Assadian. "[What is the appropriate time-interval for changing gloves during surgical procedures]."Zentralblatt fur Chirurgie 135, no. 1 (2010): 25-27.

52. Tanner, Judith, and Hazel Parkinson. "Double gloving to reduce surgical crossinfection." The Cochrane Library (2006).

53. Wulfhorst, Britta, Hans Joachim Schwanitz, and Meike Bock. "Optimizing skin protection with semipermeable gloves." Dermatitis 15, no. 4 (2004): 184-191.

54. Bernard, Thomas E., and Fasiha Matheen. "Evaporative resistance and sustainable work under heat stress conditions for two cloth anticontamination ensembles." International Journal of Industrial Ergonomics 23, no. 5 (1999): 557-564.

55. Sorock, Gary S., David A. Lombardi, Russ B. Hauser, Ellen A. Eisen, Robert F. Herrick, and Murray A. Mittleman. "A case-crossover study of occupational traumatic hand injury: methods and initial findings." American journal of industrial medicine 39, no. 2 (2001): 171-179. 
56. Macdonald, Duncan, Kaveh Sanati, and Ewan Macdonald. "The costs and characteristics of occupational injuries admitted to a trauma unit."International journal of occupational safety and ergonomics 18, no. 4 (2012): 587-590.

57. United States. Dept. of Labor. Occupational Safety and Health Administration. Personal Protective Equipment for General Industry. 59:33910-33911. Washington, DC: Government Printing Office, 1994. Online.

58. Riley, M. W., and D. J. Cochran. "ERGONOMIC ASPECTS OF GLOVES-DESIGN AND USE." International Reviews of Ergonomics 2 (1988): 233-250.

59. Bishu, R., and A. Muralidhar. "Gloves." The Occupational Ergonomics Handbook. CRC Press, New York (1999): 865-876.

60. Kovacs, Kimberly, Riley Splittstoesser, Anthony Maronitis, and William S. Marras. "Grip force and muscle activity differences due to glove type." AIHA Journal 63, no. 3 (2002): 269-274.

61 Armstrong, Thomas J., Robert G. Radwin, Doan J. Hansen, and Kenneth W. Kennedy. "Repetitive trauma disorders: job evaluation and design." Human Factors: The Journal of the Human Factors and Ergonomics Society 28, no. 3 (1986): 325-336.

62 Chengalur, SOMADEEPTI N., S. Rodgers, and T. Bernard. "Kodak's ergonomics design for people at work." (2004).

63 Bishop, Phillip, Dingliang Gu, and Anthony Clapp. "Climate under impermeable protective clothing." International Journal of Industrial Ergonomics 25, no. 3 (2000): 233-238. 
64 Havenith, George, Ingvar Holmér, and Ken Parsons. "Personal factors in thermal comfort assessment: clothing properties and metabolic heat production." Energy and buildings 34, no. 6 (2002): 581-591.

65 Gnaneswaran, V., B. Mudhunuri, and Ramaratnam R. Bishu. "A study of latex and vinyl gloves: performance versus allergy protection properties."International Journal of Industrial Ergonomics 38, no. 2 (2008): 171-181.

66 Muggleton, J. M., R. Allen, and P. H. Chappell. "Hand and arm injuries associated with repetitive manual work in industry: a review of disorders, risk factors and preventive measures." Ergonomics 42, no. 5 (1999): 714-739.

67 Ciuha, Ursa, Mikael Grönkvist, Igor B. Mekjavic, and Ola Eiken. "Strategies for increasing evaporative cooling during simulated desert patrol mission."Ergonomics 59, no. 2 (2016): 298-309.

68 Weistenhöfer, W., M. Wacker, F. Bernet, W. Uter, and H. Drexler. "Occlusive gloves and skin conditions: is there a problem? Results of a cross-sectional study in a semiconductor company." British Journal of Dermatology 172, no. 4 (2015): 1058-1065.

69 Ross, Peggy. "Ergonomic hazards in the workplace: assessment and prevention." AAOHN journal: official journal of the American Association of Occupational Health Nurses 42, no. 4 (1994): 171-176.

70 Chou, Chinmei, Yutaka Tochihara, Mohamed Saat Ismail, and Joo-Young Lee. "Physiological strains of wearing aluminized and non-aluminized firefighters' protective clothing during exercise in radiant heat." Industrial health 49, no. 2 (2011): 185-194. 


\title{
Appendix A: Participant Consent Form
}

\author{
W. West VirginiaUniversity. \\ Human Research Protocol \\ Only Minimal Risk Consent Form \\ Without HIPAA \\ Only Minimal Risk \\ Consent Information Form (without HIPAA) \\ Principal Investigator Dr. Ashish Nimbarte \\ Department Industrial Management and Systems Engineering \\ Protocol Number $\quad 1411491881$ \\ Study Title Hydration study of hand/finger/nail system to understand mechanism of glove- related \\ trauma. \\ Co-Inwestigator(s) John Kaiser \\ Sponsor (if any)
}

\section{Contact Persons}

In the event you experience any side effects or injury related to this research, you should contact Dr. Ashish Nimbarte at (304) 293-9473. (After hours contact: Dr. Ashish Nimbarte at (304) 226-8813). If you have any questions, concerns, or complaints about this research, you can contact Dr. Ashish Nimbarte at the above number or John Kaiser at (609) 4208307 .

For information regarding your rights as a research subject, to discuss problems, concerns, or suggestions related to the research, to obtain information or offer input about the research, contact the Office of Research Integrity \&. Compliance at [304) 293-7073.

In addition if you would like to discuss problems, concerns, have suggestions related to research, or would like to offer input about the research, contact the Office of Research Integrity and Compliance at 304-293-7073.

Introduction

You, , have been asked to participate in this research study, which has been explained to you by Dr. Ashish Nimbarte, Ph. D. and John Kaiser, B.S. This study is being conducted by Dr. Ashish Nimbarte, Ph.D. and John Kaiser, B.S. in the Department of Industrial and Management Systems Engineering at West Virginia University.-This research is being conducted to fulfill the requirements for a master's thesis in the area of ergonomics in the Department of Industrial and Management Systems Engineering at West Virginia University under the supervision of Dr. Ashish Nimbarte, Ph.D.

Purpose(s) of the Study

The purpose of this study is to establish baseline data for the effect the hand and fingers experiences when performing physical motions while exposed to different pressure conditions typical when using gloves that are used in outer space.

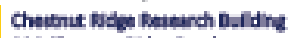

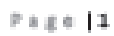

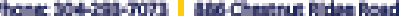

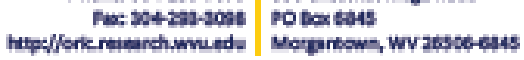

Subloct's intlale

Daite 


\section{Description of Procedures}

You will be asked to allow non-invasive skin moisture and blood flow sensors to be placed upon your hand and finger region. You will then be asked to place your hand within an enclosed chamber that is designed to change humidity and temperature levels your hand is exposed to. You will then be asked to perform several pinching and gripping motions with a pinch and grip sensor. You will be asked to remove your hands from the chamber periodically to allow for rest and chamber adjustments. This will be repeated several times until all combinations of temperature, humidity, and exertion are met. The total expected time commitment is 1.5 hours.

\section{Discomforts}

There are no known or expected risks from participating in this study, except for the mild frustration associated with answering the questions. With sufficient rest periods designed between each trial of the study, the risk of injury az a result of participation is minimal.

\section{Alternatives}

You do not have to participate in this study.

\section{Benefits}

You may not receive any direct benefit from this study. The knowledge gained from this study may eventually benefit others.

\section{Financial Considerations}

There are no special fees for participating in this study. No monetary compensation will be given to participants for participating in this study and that involvement is on a purely voluntary basis. If you are injured as a result of this research, treatment will be available. Responsibility for this treatment will be borne by: 1) the insurance company; OR 2) by you. In the event that you are physically injured as a result of participating in this research, care will be available. You will, however, be responsible for the charges for the care. There is no commitment to provide any compensation for research-related injury. You should realize, however, that you have not released this institution from liability or negligence. Please contact the investigator, Dr. Ashish Nimbarte at (304) 293-9473 if you are injured or for further information.

\section{Confidentiality}

Any information about you that is obtained as a result of your participation in this research will be kept as confidential as legally possible. Your research records and test resulta, just like hospital records, may be subpoenaed by court order or may be inspected by the study sponsor or federal regulatory authorities (including the FDA if applicable) without your additional consent.

In addition, there are certain instances where the researcher is legally required to give information to the appropriate

\begin{tabular}{|c|c|c|}
\hline 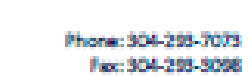 & 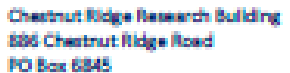 & $7=5=12$ \\
\hline hatel/foric reiswedh.wvu adu & Morgantown, WV sesce-sees & Dats \\
\hline
\end{tabular}


authorities. These would include mandatory reporting of infectious diseases, mandatory reporting of information about behavior that is imminently dangerous to your child or to others, such as suicide, child abuse, etc.

Audiotapes or videotapes will be kept locked up and will be destroyed as soon as possible after the research is finished. In any publications that result from this research, neither your name nor any information from which you might be identified will be published without your consent.

\section{Voluntary Participation}

Participation in this study is voluntary. You are free to withdraw your consent to participate in this study at any time.

Refusal to participate or withdrawal will not affect your class standing or grades and will involve no penalty to you. Refusal to participate or withdrawal will not affect your future care, or your employee status at West Virginia University.

In the event new information becomes available that may affect your willingness to participate in this study, this information will be given to you so that you can make an informed decision about whether or not to continue your participation.

You have been given the opportunity to ask questions about the research, and you have received answers concerning areas you did not understand.

Upon signing this form, you will receive a copy.

I willingly consent to participate in this research.

Signatures

Signature of Subject

Printed Name

Date

Time

The participant has had the opportunity to have questions addressed. The participant willingly agrees to be in the study.

Signature of Investigator or Co-Investigator

\begin{tabular}{lll}
\hline Printed Name & Date
\end{tabular}

\begin{tabular}{|c|c|}
\hline & Chentnut Kidge heowerdh Bulding \\
\hline Phore: $304-225-2003$ & Less Chantrut hidge ilload \\
\hline $\operatorname{cose}$ & NOB Bax Eses \\
\hline
\end{tabular}

$P=5 \times 13$



Subjectin Initien.

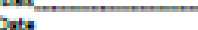




\section{Appendix B: Borg's CR-10 Scale}

\begin{tabular}{|lll|}
\hline \multicolumn{3}{|c|}{ Borg's CR-10 scale } \\
0 & Nothing at all & \\
0.5 & Extremely weak & (just noticeable) \\
1 & Very weak & \\
2 & Weak & (light) \\
3 & Moderate & \\
4 & & (heavy) \\
5 & Strong & \\
6 & & \\
7 & Very strong & \\
8 & & \\
9 & & (almost max) \\
10 & Extremely strong &
\end{tabular}




\section{Appendix C: Perceived Discomfort Data Table}

\begin{tabular}{|c|c|c|c|c|c|c|}
\hline Sub & Temp & $\begin{array}{l}\text { Humidit } \\
\mathrm{y}\end{array}$ & Exertion & Rep & Discomfort & $\begin{array}{l}\text { Normalized } \\
\text { Discomfort }\end{array}$ \\
\hline 1 & $65-75$ & $35-45$ & $\begin{array}{l}\text { No } \\
\text { exertion }\end{array}$ & 1 & 2 & 0.25 \\
\hline 1 & $65-75$ & $35-45$ & $\begin{array}{l}\text { No } \\
\text { exertion }\end{array}$ & 2 & 2 & 0.25 \\
\hline 1 & $65-75$ & $35-45$ & exertion & 1 & 3 & 0.375 \\
\hline 1 & $65-75$ & $35-45$ & exertion & 2 & 5 & 0.625 \\
\hline 1 & $65-75$ & $55-65$ & $\begin{array}{l}\text { No } \\
\text { exertion }\end{array}$ & 1 & 2 & 0.25 \\
\hline 1 & $65-75$ & $55-65$ & $\begin{array}{l}\text { No } \\
\text { exertion }\end{array}$ & 2 & 3 & 0.375 \\
\hline 1 & $65-75$ & $55-65$ & exertion & 1 & 5 & 0.625 \\
\hline 1 & $65-75$ & $55-65$ & exertion & 2 & 5 & 0.625 \\
\hline 1 & $85-95$ & $35-45$ & $\begin{array}{l}\text { No } \\
\text { exertion }\end{array}$ & 1 & 2 & 0.25 \\
\hline 1 & $85-95$ & $35-45$ & $\begin{array}{l}\text { No } \\
\text { exertion }\end{array}$ & 2 & 1 & 0.125 \\
\hline 1 & $85-95$ & $35-45$ & exertion & 1 & 6 & 0.75 \\
\hline 1 & $85-95$ & $35-45$ & exertion & 2 & 8 & 1 \\
\hline 1 & $85-95$ & $55-65$ & $\begin{array}{l}\text { No } \\
\text { exertion }\end{array}$ & 1 & 1 & 0.125 \\
\hline 1 & $85-95$ & $55-65$ & $\begin{array}{l}\text { No } \\
\text { exertion }\end{array}$ & 2 & 2 & 0.25 \\
\hline 1 & $85-95$ & $55-65$ & exertion & 1 & 7 & 0.875 \\
\hline 1 & $85-95$ & $55-65$ & exertion & 2 & 8 & 1 \\
\hline 2 & $65-75$ & $35-45$ & $\begin{array}{l}\text { No } \\
\text { exertion }\end{array}$ & 1 & 1 & 0.166666667 \\
\hline 2 & $65-75$ & $35-45$ & $\begin{array}{l}\text { No } \\
\text { exertion }\end{array}$ & 2 & 2 & 0.333333333 \\
\hline 2 & $65-75$ & $35-45$ & exertion & 1 & 4 & 0.6666666667 \\
\hline 2 & $65-75$ & $35-45$ & exertion & 2 & 2 & 0.333333333 \\
\hline 2 & $65-75$ & $55-65$ & $\begin{array}{l}\text { No } \\
\text { exertion }\end{array}$ & 1 & 1 & 0.166666667 \\
\hline 2 & $65-75$ & $55-65$ & $\begin{array}{l}\text { No } \\
\text { exertion }\end{array}$ & 2 & 1 & 0.166666667 \\
\hline 2 & $65-75$ & $55-65$ & exertion & 1 & 6 & 1 \\
\hline 2 & $65-75$ & $55-65$ & exertion & 2 & 6 & 1 \\
\hline 2 & $85-95$ & $35-45$ & $\begin{array}{l}\text { No } \\
\text { exertion }\end{array}$ & 1 & 2 & 0.333333333 \\
\hline
\end{tabular}




\begin{tabular}{|c|c|c|c|c|c|c|}
\hline 2 & $85-95$ & $35-45$ & $\begin{array}{l}\text { No } \\
\text { exertion }\end{array}$ & 2 & 1 & 0.166666667 \\
\hline 2 & $85-95$ & $35-45$ & exertion & 1 & 5 & 0.833333333 \\
\hline 2 & $85-95$ & $35-45$ & exertion & 2 & 5 & 0.833333333 \\
\hline 2 & $85-95$ & $55-65$ & $\begin{array}{l}\text { No } \\
\text { exertion }\end{array}$ & 1 & 1 & 0.166666667 \\
\hline 2 & $85-95$ & $55-65$ & $\begin{array}{l}\text { No } \\
\text { exertion }\end{array}$ & 2 & 1 & 0.166666667 \\
\hline 2 & $85-95$ & $55-65$ & exertion & 1 & 4 & 0.666666667 \\
\hline 2 & $85-95$ & $55-65$ & exertion & 2 & 6 & 1 \\
\hline 3 & $65-75$ & $35-45$ & $\begin{array}{l}\text { No } \\
\text { exertion }\end{array}$ & 1 & 4 & 0.666666667 \\
\hline 3 & $65-75$ & $35-45$ & $\begin{array}{l}\text { No } \\
\text { exertion }\end{array}$ & 2 & 3 & 0.5 \\
\hline 3 & $65-75$ & $35-45$ & exertion & 1 & 1 & 0.166666667 \\
\hline 3 & $65-75$ & $35-45$ & exertion & 2 & 2 & 0.333333333 \\
\hline 3 & $65-75$ & $55-65$ & $\begin{array}{l}\text { No } \\
\text { exertion }\end{array}$ & 1 & 2 & 0.333333333 \\
\hline 3 & $65-75$ & $55-65$ & $\begin{array}{l}\text { No } \\
\text { exertion }\end{array}$ & 2 & 5 & 0.833333333 \\
\hline 3 & $65-75$ & $55-65$ & exertion & 1 & 2 & 0.333333333 \\
\hline 3 & $65-75$ & $55-65$ & exertion & 2 & 4 & 0.666666667 \\
\hline 3 & $85-95$ & $35-45$ & $\begin{array}{l}\text { No } \\
\text { exertion }\end{array}$ & 1 & 5 & 0.833333333 \\
\hline 3 & $85-95$ & $35-45$ & $\begin{array}{l}\text { No } \\
\text { exertion }\end{array}$ & 2 & 3 & 0.5 \\
\hline 3 & $85-95$ & $35-45$ & exertion & 1 & 4 & 0.666666667 \\
\hline 3 & $85-95$ & $35-45$ & exertion & 2 & 3 & 0.5 \\
\hline 3 & $85-95$ & $55-65$ & $\begin{array}{l}\text { No } \\
\text { exertion }\end{array}$ & 1 & 4 & 0.666666667 \\
\hline 3 & $85-95$ & $55-65$ & $\begin{array}{l}\text { No } \\
\text { exertion }\end{array}$ & 2 & 6 & 1 \\
\hline 3 & $85-95$ & $55-65$ & exertion & 1 & 5 & 0.833333333 \\
\hline 3 & $85-95$ & $55-65$ & exertion & 2 & 4 & 0.666666667 \\
\hline 4 & $65-75$ & $35-45$ & $\begin{array}{l}\text { No } \\
\text { exertion }\end{array}$ & 1 & 1 & 0.125 \\
\hline 4 & $65-75$ & $35-45$ & $\begin{array}{l}\text { No } \\
\text { exertion }\end{array}$ & 2 & 1 & 0.125 \\
\hline 4 & $65-75$ & $35-45$ & exertion & 1 & 3 & 0.375 \\
\hline 4 & $65-75$ & $35-45$ & exertion & 2 & 4 & 0.5 \\
\hline 4 & $65-75$ & $55-65$ & $\begin{array}{l}\text { No } \\
\text { exertion }\end{array}$ & 1 & 1 & 0.125 \\
\hline
\end{tabular}




\begin{tabular}{|c|c|c|c|c|c|c|}
\hline 4 & $65-75$ & $55-65$ & $\begin{array}{l}\text { No } \\
\text { exertion }\end{array}$ & 2 & 1 & 0.125 \\
\hline 4 & $65-75$ & $55-65$ & exertion & 1 & 4 & 0.5 \\
\hline 4 & $65-75$ & $55-65$ & exertion & 2 & 5 & 0.625 \\
\hline 4 & $85-95$ & $35-45$ & $\begin{array}{l}\text { No } \\
\text { exertion }\end{array}$ & 1 & 7 & 0.875 \\
\hline 4 & $85-95$ & $35-45$ & $\begin{array}{l}\text { No } \\
\text { exertion }\end{array}$ & 2 & 5 & 0.625 \\
\hline 4 & $85-95$ & $35-45$ & exertion & 1 & 6 & 0.75 \\
\hline 4 & $85-95$ & $35-45$ & exertion & 2 & 8 & 1 \\
\hline 4 & $85-95$ & $55-65$ & $\begin{array}{l}\text { No } \\
\text { exertion }\end{array}$ & 1 & 6 & 0.75 \\
\hline 4 & $85-95$ & $55-65$ & $\begin{array}{l}\text { No } \\
\text { exertion }\end{array}$ & 2 & 8 & 1 \\
\hline 4 & $85-95$ & $55-65$ & exertion & 1 & 8 & 1 \\
\hline 4 & $85-95$ & $55-65$ & exertion & 2 & 8 & 1 \\
\hline 5 & $65-75$ & $35-45$ & $\begin{array}{l}\text { No } \\
\text { exertion }\end{array}$ & 1 & 1 & 0.333333333 \\
\hline 5 & $65-75$ & $35-45$ & $\begin{array}{l}\text { No } \\
\text { exertion }\end{array}$ & 2 & 1 & 0.333333333 \\
\hline 5 & $65-75$ & $35-45$ & exertion & 1 & 3 & 1 \\
\hline 5 & $65-75$ & $35-45$ & exertion & 2 & 3 & 1 \\
\hline 5 & $65-75$ & $55-65$ & $\begin{array}{l}\text { No } \\
\text { exertion }\end{array}$ & 1 & 1 & 0.333333333 \\
\hline 5 & $65-75$ & $55-65$ & $\begin{array}{l}\text { No } \\
\text { exertion }\end{array}$ & 2 & 1 & 0.333333333 \\
\hline 5 & $65-75$ & $55-65$ & exertion & 1 & 2 & 0.666666667 \\
\hline 5 & $65-75$ & $55-65$ & exertion & 2 & 3 & 1 \\
\hline 5 & $85-95$ & $35-45$ & $\begin{array}{l}\text { No } \\
\text { exertion }\end{array}$ & 1 & 2 & 0.666666667 \\
\hline 5 & $85-95$ & $35-45$ & $\begin{array}{l}\text { No } \\
\text { exertion }\end{array}$ & 2 & 1 & 0.333333333 \\
\hline 5 & $85-95$ & $35-45$ & exertion & 1 & 2 & 0.666666667 \\
\hline 5 & $85-95$ & $35-45$ & exertion & 2 & 2 & 0.666666667 \\
\hline 5 & $85-95$ & $55-65$ & $\begin{array}{l}\text { No } \\
\text { exertion }\end{array}$ & 1 & 2 & 0.666666667 \\
\hline 5 & $85-95$ & $55-65$ & $\begin{array}{l}\text { No } \\
\text { exertion }\end{array}$ & 2 & 1 & 0.333333333 \\
\hline 5 & $85-95$ & $55-65$ & exertion & 1 & 2 & 0.666666667 \\
\hline 5 & $85-95$ & $55-65$ & exertion & 2 & 2 & 0.666666667 \\
\hline 7 & $65-75$ & $35-45$ & $\begin{array}{l}\text { No } \\
\text { exertion }\end{array}$ & 1 & 1 & 0.1 \\
\hline
\end{tabular}




\begin{tabular}{|c|c|c|c|c|c|c|}
\hline 7 & $65-75$ & $35-45$ & $\begin{array}{l}\text { No } \\
\text { exertion }\end{array}$ & 2 & 1 & 0.1 \\
\hline 7 & $65-75$ & $35-45$ & exertion & 1 & 4 & 0.4 \\
\hline 7 & $65-75$ & $35-45$ & exertion & 2 & 5 & 0.5 \\
\hline 7 & $65-75$ & $55-65$ & $\begin{array}{l}\text { No } \\
\text { exertion }\end{array}$ & 1 & 1 & 0.1 \\
\hline 7 & $65-75$ & $55-65$ & $\begin{array}{l}\text { No } \\
\text { exertion }\end{array}$ & 2 & 1 & 0.1 \\
\hline 7 & $65-75$ & $55-65$ & exertion & 1 & 4 & 0.4 \\
\hline 7 & $65-75$ & $55-65$ & exertion & 2 & 6 & 0.6 \\
\hline 7 & $85-95$ & $35-45$ & $\begin{array}{l}\text { No } \\
\text { exertion }\end{array}$ & 1 & 4 & 0.4 \\
\hline 7 & $85-95$ & $35-45$ & $\begin{array}{l}\text { No } \\
\text { exertion }\end{array}$ & 2 & 3 & 0.3 \\
\hline 7 & $85-95$ & $35-45$ & exertion & 1 & 8 & 0.8 \\
\hline 7 & $85-95$ & $35-45$ & exertion & 2 & 9 & 0.9 \\
\hline 7 & $85-95$ & $55-65$ & $\begin{array}{l}\text { No } \\
\text { exertion }\end{array}$ & 1 & 8 & 0.8 \\
\hline 7 & $85-95$ & $55-65$ & $\begin{array}{l}\text { No } \\
\text { exertion }\end{array}$ & 2 & 9 & 0.9 \\
\hline 7 & $85-95$ & $55-65$ & exertion & 1 & 8 & 0.8 \\
\hline 7 & $85-95$ & $55-65$ & exertion & 2 & 10 & 1 \\
\hline 8 & $65-75$ & $35-45$ & $\begin{array}{l}\text { No } \\
\text { exertion }\end{array}$ & 1 & 1 & 0.333333333 \\
\hline 8 & $65-75$ & $35-45$ & $\begin{array}{l}\text { No } \\
\text { exertion }\end{array}$ & 2 & 1 & 0.333333333 \\
\hline 8 & $65-75$ & $35-45$ & exertion & 1 & 1 & 0.333333333 \\
\hline 8 & $65-75$ & $35-45$ & exertion & 2 & 1 & 0.333333333 \\
\hline 8 & $65-75$ & $55-65$ & $\begin{array}{l}\text { No } \\
\text { exertion }\end{array}$ & 1 & 1 & 0.333333333 \\
\hline 8 & $65-75$ & $55-65$ & $\begin{array}{l}\text { No } \\
\text { exertion }\end{array}$ & 2 & 1 & 0.333333333 \\
\hline 8 & $65-75$ & $55-65$ & exertion & 1 & 2 & 0.666666667 \\
\hline 8 & $65-75$ & $55-65$ & exertion & 2 & 2 & 0.666666667 \\
\hline 8 & $85-95$ & $35-45$ & $\begin{array}{l}\text { No } \\
\text { exertion }\end{array}$ & 1 & 2 & 0.666666667 \\
\hline 8 & $85-95$ & $35-45$ & $\begin{array}{l}\text { No } \\
\text { exertion }\end{array}$ & 2 & 1 & 0.333333333 \\
\hline 8 & $85-95$ & $35-45$ & exertion & 1 & 3 & 1 \\
\hline 8 & $85-95$ & $35-45$ & exertion & 2 & 3 & 1 \\
\hline 8 & $85-95$ & $55-65$ & $\begin{array}{l}\text { No } \\
\text { exertion }\end{array}$ & 1 & 1 & 0.333333333 \\
\hline
\end{tabular}




\begin{tabular}{|c|c|c|c|c|c|c|}
\hline 8 & $85-95$ & $55-65$ & $\begin{array}{l}\text { No } \\
\text { exertion }\end{array}$ & 2 & 1 & 0.333333333 \\
\hline 8 & $85-95$ & $55-65$ & exertion & 1 & 1 & 0.333333333 \\
\hline 8 & $85-95$ & $55-65$ & exertion & 2 & 2 & 0.666666667 \\
\hline 9 & $65-75$ & $35-45$ & $\begin{array}{l}\text { No } \\
\text { exertion }\end{array}$ & 1 & 1 & 0.333333333 \\
\hline 9 & $65-75$ & $35-45$ & $\begin{array}{l}\text { No } \\
\text { exertion }\end{array}$ & 2 & 1 & 0.333333333 \\
\hline 9 & $65-75$ & $35-45$ & exertion & 1 & 2 & 0.666666667 \\
\hline 9 & $65-75$ & $35-45$ & exertion & 2 & 1 & 0.333333333 \\
\hline 9 & $65-75$ & $55-65$ & $\begin{array}{l}\text { No } \\
\text { exertion }\end{array}$ & 1 & 3 & 1 \\
\hline 9 & $65-75$ & $55-65$ & $\begin{array}{l}\text { No } \\
\text { exertion }\end{array}$ & 2 & 2 & 0.666666667 \\
\hline 9 & $65-75$ & $55-65$ & exertion & 1 & 1 & 0.333333333 \\
\hline 9 & $65-75$ & $55-65$ & exertion & 2 & 3 & 1 \\
\hline 9 & $85-95$ & $35-45$ & $\begin{array}{l}\text { No } \\
\text { exertion }\end{array}$ & 1 & 2 & 0.666666667 \\
\hline 9 & $85-95$ & $35-45$ & $\begin{array}{l}\text { No } \\
\text { exertion }\end{array}$ & 2 & 3 & 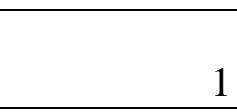 \\
\hline 9 & $85-95$ & $35-45$ & exertion & 1 & 1 & 0.333333333 \\
\hline 9 & $85-95$ & $35-45$ & exertion & 2 & 3 & 1 \\
\hline 9 & $85-95$ & $55-65$ & $\begin{array}{l}\text { No } \\
\text { exertion }\end{array}$ & 1 & 1 & 0.333333333 \\
\hline 9 & $85-95$ & $55-65$ & $\begin{array}{l}\text { No } \\
\text { exertion }\end{array}$ & 2 & 2 & 0.666666667 \\
\hline 9 & $85-95$ & $55-65$ & exertion & 1 & 1 & 0.333333333 \\
\hline 9 & $85-95$ & $55-65$ & exertion & 2 & 3 & 1 \\
\hline 10 & $65-75$ & $35-45$ & $\begin{array}{l}\text { No } \\
\text { exertion }\end{array}$ & 1 & 1 & 0.166666667 \\
\hline 10 & $65-75$ & $35-45$ & $\begin{array}{l}\text { No } \\
\text { exertion }\end{array}$ & 2 & 1 & 0.166666667 \\
\hline 10 & $65-75$ & $35-45$ & exertion & 1 & 1 & 0.166666667 \\
\hline 10 & $65-75$ & $35-45$ & exertion & 2 & 1 & 0.166666667 \\
\hline 10 & $65-75$ & $55-65$ & $\begin{array}{l}\text { No } \\
\text { exertion }\end{array}$ & 1 & 1 & 0.166666667 \\
\hline 10 & $65-75$ & $55-65$ & $\begin{array}{l}\text { No } \\
\text { exertion }\end{array}$ & 2 & 1 & 0.166666667 \\
\hline 10 & $65-75$ & $55-65$ & exertion & 1 & 1 & 0.166666667 \\
\hline 10 & $65-75$ & $55-65$ & exertion & 2 & 1 & 0.166666667 \\
\hline 10 & $85-95$ & $35-45$ & $\begin{array}{l}\text { No } \\
\text { exertion }\end{array}$ & 1 & 1 & 0.166666667 \\
\hline
\end{tabular}




\begin{tabular}{|c|c|c|c|c|c|c|}
\hline 10 & $85-95$ & $35-45$ & $\begin{array}{l}\text { No } \\
\text { exertion }\end{array}$ & 2 & 1 & 0.166666667 \\
\hline 10 & $85-95$ & $35-45$ & exertion & 1 & 1 & 0.166666667 \\
\hline 10 & $85-95$ & $35-45$ & exertion & 2 & 6 & 1 \\
\hline 10 & $85-95$ & $55-65$ & $\begin{array}{l}\text { No } \\
\text { exertion }\end{array}$ & 1 & 1 & 0.166666667 \\
\hline 10 & $85-95$ & $55-65$ & $\begin{array}{l}\text { No } \\
\text { exertion }\end{array}$ & 2 & 1 & 0.166666667 \\
\hline 10 & $85-95$ & $55-65$ & exertion & 1 & 4 & 0.666666667 \\
\hline 10 & $85-95$ & $55-65$ & exertion & 2 & 5 & 0.833333333 \\
\hline 11 & $65-75$ & $35-45$ & $\begin{array}{l}\text { No } \\
\text { exertion }\end{array}$ & 1 & 1 & 0.2 \\
\hline 11 & $65-75$ & $35-45$ & $\begin{array}{l}\text { No } \\
\text { exertion }\end{array}$ & 2 & 3 & 0.6 \\
\hline 11 & $65-75$ & $35-45$ & exertion & 1 & 3 & 0.6 \\
\hline 11 & $65-75$ & $35-45$ & exertion & 2 & 3 & 0.6 \\
\hline 11 & $65-75$ & $55-65$ & $\begin{array}{l}\text { No } \\
\text { exertion }\end{array}$ & 1 & 2 & 0.4 \\
\hline 11 & $65-75$ & $55-65$ & $\begin{array}{l}\text { No } \\
\text { exertion }\end{array}$ & 2 & 1 & 0.2 \\
\hline 11 & $65-75$ & 55-65 & exertion & 1 & 1 & 0.2 \\
\hline 11 & $65-75$ & $55-65$ & exertion & 2 & 3 & 0.6 \\
\hline 11 & $85-95$ & $35-45$ & $\begin{array}{l}\text { No } \\
\text { exertion }\end{array}$ & 1 & 5 & 1 \\
\hline 11 & $85-95$ & $35-45$ & $\begin{array}{l}\text { No } \\
\text { exertion }\end{array}$ & 2 & 4 & 0.8 \\
\hline 11 & $85-95$ & $35-45$ & exertion & 1 & 4 & 0.8 \\
\hline 11 & $85-95$ & $35-45$ & exertion & 2 & 3 & 0.6 \\
\hline 11 & $85-95$ & $55-65$ & $\begin{array}{l}\text { No } \\
\text { exertion }\end{array}$ & 1 & 3 & 0.6 \\
\hline 11 & $85-95$ & $55-65$ & $\begin{array}{l}\text { No } \\
\text { exertion }\end{array}$ & 2 & 3 & 0.6 \\
\hline 11 & $85-95$ & $55-65$ & exertion & 1 & 4 & 0.8 \\
\hline 11 & $85-95$ & $55-65$ & exertion & 2 & 3 & 0.6 \\
\hline 12 & $65-75$ & $35-45$ & $\begin{array}{l}\text { No } \\
\text { exertion }\end{array}$ & 1 & 2 & 0.666666667 \\
\hline 12 & $65-75$ & $35-45$ & $\begin{array}{l}\text { No } \\
\text { exertion }\end{array}$ & 2 & 1 & 0.333333333 \\
\hline 12 & $65-75$ & $35-45$ & exertion & 1 & 3 & 1 \\
\hline 12 & $65-75$ & $35-45$ & exertion & 2 & 3 & 1 \\
\hline 12 & $65-75$ & $55-65$ & $\begin{array}{l}\text { No } \\
\text { exertion }\end{array}$ & 1 & 1 & 0.333333333 \\
\hline
\end{tabular}




\begin{tabular}{|c|c|c|c|c|c|c|}
\hline 12 & $65-75$ & $55-65$ & $\begin{array}{l}\text { No } \\
\text { exertion }\end{array}$ & 2 & 2 & 0.666666667 \\
\hline 12 & $65-75$ & $55-65$ & exertion & 1 & 1 & 0.333333333 \\
\hline 12 & $65-75$ & $55-65$ & exertion & 2 & 1 & 0.333333333 \\
\hline 12 & $85-95$ & $35-45$ & $\begin{array}{l}\text { No } \\
\text { exertion }\end{array}$ & 1 & 2 & 0.666666667 \\
\hline 12 & $85-95$ & $35-45$ & $\begin{array}{l}\text { No } \\
\text { exertion }\end{array}$ & 2 & 2 & 0.666666667 \\
\hline 12 & $85-95$ & $35-45$ & exertion & 1 & 2 & 0.666666667 \\
\hline 12 & $85-95$ & $35-45$ & exertion & 2 & 2 & 0.666666667 \\
\hline 12 & $85-95$ & $55-65$ & $\begin{array}{l}\text { No } \\
\text { exertion }\end{array}$ & 1 & 1 & 0.333333333 \\
\hline 12 & $85-95$ & $55-65$ & $\begin{array}{l}\text { No } \\
\text { exertion }\end{array}$ & 2 & 2 & 0.666666667 \\
\hline 12 & $85-95$ & $55-65$ & exertion & 1 & 3 & 1 \\
\hline 12 & $85-95$ & $55-65$ & exertion & 2 & 3 & 1 \\
\hline 13 & $65-75$ & $35-45$ & $\begin{array}{l}\text { No } \\
\text { exertion }\end{array}$ & 1 & 1 & 0.5 \\
\hline 13 & $65-75$ & $35-45$ & $\begin{array}{l}\text { No } \\
\text { exertion }\end{array}$ & 2 & 1 & 0.5 \\
\hline 13 & $65-75$ & $35-45$ & exertion & 1 & 1 & 0.5 \\
\hline 13 & $65-75$ & $35-45$ & exertion & 2 & 2 & 1 \\
\hline 13 & $65-75$ & $55-65$ & $\begin{array}{l}\text { No } \\
\text { exertion }\end{array}$ & 1 & 1 & 0.5 \\
\hline 13 & $65-75$ & $55-65$ & $\begin{array}{l}\text { No } \\
\text { exertion }\end{array}$ & 2 & 1 & 0.5 \\
\hline 13 & $65-75$ & $55-65$ & exertion & 1 & 2 & 1 \\
\hline 13 & $65-75$ & $55-65$ & exertion & 2 & 1 & 0.5 \\
\hline 13 & $85-95$ & $35-45$ & $\begin{array}{l}\text { No } \\
\text { exertion }\end{array}$ & 1 & 1 & 0.5 \\
\hline 13 & $85-95$ & $35-45$ & $\begin{array}{l}\text { No } \\
\text { exertion }\end{array}$ & 2 & 1 & 0.5 \\
\hline 13 & $85-95$ & $35-45$ & exertion & 1 & 1 & 0.5 \\
\hline 13 & $85-95$ & $35-45$ & exertion & 2 & 1 & 0.5 \\
\hline 13 & $85-95$ & $55-65$ & $\begin{array}{l}\text { No } \\
\text { exertion }\end{array}$ & 1 & 1 & 0.5 \\
\hline 13 & $85-95$ & $55-65$ & $\begin{array}{l}\text { No } \\
\text { exertion }\end{array}$ & 2 & 1 & 0.5 \\
\hline 13 & $85-95$ & $55-65$ & exertion & 1 & 1 & 0.5 \\
\hline 13 & $85-95$ & $55-65$ & exertion & 2 & 1 & 0.5 \\
\hline 14 & $65-75$ & $35-45$ & $\begin{array}{l}\text { No } \\
\text { exertion }\end{array}$ & 1 & 3.5 & 0.4375 \\
\hline
\end{tabular}




\begin{tabular}{|c|c|c|c|c|c|c|}
\hline 14 & $65-75$ & $35-45$ & $\begin{array}{l}\text { No } \\
\text { exertion }\end{array}$ & 2 & 2 & 0.25 \\
\hline 14 & $65-75$ & $35-45$ & exertion & 1 & 1 & 0.125 \\
\hline 14 & $65-75$ & $35-45$ & exertion & 2 & 1 & 0.125 \\
\hline 14 & $65-75$ & $55-65$ & $\begin{array}{l}\text { No } \\
\text { exertion }\end{array}$ & 1 & 3 & 0.375 \\
\hline 14 & $65-75$ & $55-65$ & $\begin{array}{l}\text { No } \\
\text { exertion }\end{array}$ & 2 & 1 & 0.125 \\
\hline 14 & $65-75$ & $55-65$ & exertion & 1 & 1.5 & 0.1875 \\
\hline 14 & $65-75$ & $55-65$ & exertion & 2 & 1 & 0.125 \\
\hline 14 & $85-95$ & $35-45$ & $\begin{array}{l}\text { No } \\
\text { exertion }\end{array}$ & 1 & 3 & 0.375 \\
\hline 14 & $85-95$ & $35-45$ & $\begin{array}{l}\text { No } \\
\text { exertion }\end{array}$ & 2 & 2 & 0.25 \\
\hline 14 & $85-95$ & $35-45$ & exertion & 1 & 1 & 0.125 \\
\hline 14 & $85-95$ & $35-45$ & exertion & 2 & 1 & 0.125 \\
\hline 14 & $85-95$ & $55-65$ & $\begin{array}{l}\text { No } \\
\text { exertion }\end{array}$ & 1 & 8 & 1 \\
\hline 14 & $85-95$ & $55-65$ & $\begin{array}{l}\text { No } \\
\text { exertion }\end{array}$ & 2 & 1 & 0.125 \\
\hline 14 & 85-95 & 55-65 & exertion & 1 & 4 & 0.5 \\
\hline 14 & $85-95$ & $55-65$ & exertion & 2 & 6 & 0.75 \\
\hline 18 & $65-75$ & $35-45$ & $\begin{array}{l}\text { No } \\
\text { exertion }\end{array}$ & 1 & 1 & 0.125 \\
\hline 18 & $65-75$ & $35-45$ & $\begin{array}{l}\text { No } \\
\text { exertion }\end{array}$ & 2 & 1 & 0.125 \\
\hline 18 & $65-75$ & $35-45$ & exertion & 1 & 2 & 0.25 \\
\hline 18 & $65-75$ & $35-45$ & exertion & 2 & 3 & 0.375 \\
\hline 18 & $65-75$ & $55-65$ & $\begin{array}{l}\text { No } \\
\text { exertion }\end{array}$ & 1 & 2 & 0.25 \\
\hline 18 & $65-75$ & $55-65$ & $\begin{array}{l}\text { No } \\
\text { exertion }\end{array}$ & 2 & 3 & 0.375 \\
\hline 18 & $65-75$ & $55-65$ & exertion & 1 & 4 & 0.5 \\
\hline 18 & $65-75$ & $55-65$ & exertion & 2 & 5 & 0.625 \\
\hline 18 & 85-95 & $35-45$ & $\begin{array}{l}\text { No } \\
\text { exertion }\end{array}$ & 1 & 2 & 0.25 \\
\hline 18 & $85-95$ & $35-45$ & $\begin{array}{l}\text { No } \\
\text { exertion }\end{array}$ & 2 & 2 & 0.25 \\
\hline 18 & $85-95$ & $35-45$ & exertion & 1 & 7 & 0.875 \\
\hline 18 & $85-95$ & $35-45$ & exertion & 2 & 6 & 0.75 \\
\hline 18 & $85-95$ & $55-65$ & $\begin{array}{l}\text { No } \\
\text { exertion }\end{array}$ & 1 & 3 & 0.375 \\
\hline
\end{tabular}




\begin{tabular}{|c|c|c|c|c|c|c|}
\hline 18 & $85-95$ & $55-65$ & $\begin{array}{l}\text { No } \\
\text { exertion }\end{array}$ & 2 & 2 & 0.25 \\
\hline 18 & $85-95$ & $55-65$ & exertion & 1 & 7 & 0.875 \\
\hline 18 & $85-95$ & $55-65$ & exertion & 2 & 8 & 1 \\
\hline 19 & $65-75$ & $35-45$ & $\begin{array}{l}\text { No } \\
\text { exertion }\end{array}$ & 1 & 1 & 0.166666667 \\
\hline 19 & $65-75$ & $35-45$ & $\begin{array}{l}\text { No } \\
\text { exertion }\end{array}$ & 2 & 1 & 0.166666667 \\
\hline 19 & $65-75$ & $35-45$ & exertion & 1 & 4 & 0.666666667 \\
\hline 19 & $65-75$ & $35-45$ & exertion & 2 & 4 & 0.666666667 \\
\hline 19 & $65-75$ & $55-65$ & $\begin{array}{l}\text { No } \\
\text { exertion }\end{array}$ & 1 & 1 & 0.166666667 \\
\hline 19 & $65-75$ & $55-65$ & $\begin{array}{l}\text { No } \\
\text { exertion }\end{array}$ & 2 & 1 & 0.166666667 \\
\hline 19 & $65-75$ & $55-65$ & exertion & 1 & 5 & 0.833333333 \\
\hline 19 & $65-75$ & $55-65$ & exertion & 2 & 4 & 0.666666667 \\
\hline 19 & $85-95$ & $35-45$ & $\begin{array}{l}\text { No } \\
\text { exertion }\end{array}$ & 1 & 1 & 0.166666667 \\
\hline 19 & $85-95$ & $35-45$ & $\begin{array}{l}\text { No } \\
\text { exertion }\end{array}$ & 2 & 1 & 0.166666667 \\
\hline 19 & $85-95$ & $35-45$ & exertion & 1 & 6 & 1 \\
\hline 19 & $85-95$ & $35-45$ & exertion & 2 & 6 & 1 \\
\hline 19 & $85-95$ & $55-65$ & $\begin{array}{l}\text { No } \\
\text { exertion }\end{array}$ & 1 & 1 & 0.166666667 \\
\hline 19 & $85-95$ & $55-65$ & $\begin{array}{l}\text { No } \\
\text { exertion }\end{array}$ & 2 & 2 & 0.333333333 \\
\hline 19 & $85-95$ & $55-65$ & exertion & 1 & 5 & 0.833333333 \\
\hline 19 & $85-95$ & $55-65$ & exertion & 2 & 4 & 0.666666667 \\
\hline 20 & $65-75$ & $35-45$ & $\begin{array}{l}\text { No } \\
\text { exertion }\end{array}$ & 1 & 1 & 0.166666667 \\
\hline 20 & $65-75$ & $35-45$ & $\begin{array}{l}\text { No } \\
\text { exertion }\end{array}$ & 2 & 1 & 0.166666667 \\
\hline 20 & $65-75$ & $35-45$ & exertion & 1 & 2 & 0.333333333 \\
\hline 20 & $65-75$ & $35-45$ & exertion & 2 & 3 & 0.5 \\
\hline 20 & $65-75$ & $55-65$ & $\begin{array}{l}\text { No } \\
\text { exertion }\end{array}$ & 1 & 1 & 0.166666667 \\
\hline 20 & $65-75$ & $55-65$ & $\begin{array}{l}\text { No } \\
\text { exertion }\end{array}$ & 2 & N/A & \\
\hline 20 & $65-75$ & $55-65$ & exertion & 1 & 4 & 0.666666667 \\
\hline 20 & $65-75$ & $55-65$ & exertion & 2 & N/A & \\
\hline 20 & $85-95$ & $35-45$ & $\begin{array}{l}\text { No } \\
\text { exertion }\end{array}$ & 1 & 3 & 0.5 \\
\hline
\end{tabular}




\begin{tabular}{|c|c|c|c|c|c|c|}
\hline 20 & $85-95$ & $35-45$ & $\begin{array}{l}\text { No } \\
\text { exertion }\end{array}$ & 2 & 1 & 0.166666667 \\
\hline 20 & $85-95$ & $35-45$ & exertion & 1 & 5 & 0.833333333 \\
\hline 20 & $85-95$ & $35-45$ & exertion & 2 & 5 & 0.833333333 \\
\hline 20 & $85-95$ & $55-65$ & $\begin{array}{l}\text { No } \\
\text { exertion }\end{array}$ & 1 & 2 & 0.333333333 \\
\hline 20 & $85-95$ & $55-65$ & $\begin{array}{l}\text { No } \\
\text { exertion }\end{array}$ & 2 & 3 & 0.5 \\
\hline 20 & $85-95$ & $55-65$ & exertion & 1 & 5 & 0.833333333 \\
\hline 20 & $85-95$ & $55-65$ & exertion & 2 & 6 & 1 \\
\hline 21 & $65-75$ & $35-45$ & $\begin{array}{l}\text { No } \\
\text { exertion }\end{array}$ & 1 & 1 & 0.2 \\
\hline 21 & $65-75$ & $35-45$ & $\begin{array}{l}\text { No } \\
\text { exertion }\end{array}$ & 2 & 1 & 0.2 \\
\hline 21 & $65-75$ & $35-45$ & exertion & 1 & 2 & 0.4 \\
\hline 21 & $65-75$ & $35-45$ & exertion & 2 & 2 & 0.4 \\
\hline 21 & $65-75$ & $55-65$ & $\begin{array}{l}\text { No } \\
\text { exertion }\end{array}$ & 1 & 1 & 0.2 \\
\hline 21 & $65-75$ & $55-65$ & $\begin{array}{l}\text { No } \\
\text { exertion }\end{array}$ & 2 & 1 & 0.2 \\
\hline 21 & $65-75$ & $55-65$ & exertion & 1 & 2 & 0.4 \\
\hline 21 & $65-75$ & $55-65$ & exertion & 2 & 3 & 0.6 \\
\hline 21 & $85-95$ & $35-45$ & $\begin{array}{l}\text { No } \\
\text { exertion }\end{array}$ & 1 & 3 & 0.6 \\
\hline 21 & $85-95$ & $35-45$ & $\begin{array}{l}\text { No } \\
\text { exertion }\end{array}$ & 2 & 2 & 0.4 \\
\hline 21 & $85-95$ & $35-45$ & exertion & 1 & 3 & 0.6 \\
\hline 21 & $85-95$ & $35-45$ & exertion & 2 & 5 & 1 \\
\hline 21 & $85-95$ & $55-65$ & $\begin{array}{l}\text { No } \\
\text { exertion }\end{array}$ & 1 & 4 & 0.8 \\
\hline 21 & $85-95$ & $55-65$ & $\begin{array}{l}\text { No } \\
\text { exertion }\end{array}$ & 2 & 2 & 0.4 \\
\hline 21 & $85-95$ & $55-65$ & exertion & 1 & 5 & 1 \\
\hline 21 & $85-95$ & $55-65$ & exertion & 2 & 3 & 0.6 \\
\hline
\end{tabular}




\section{Appendix D: Skin Conductance Data Table}

\begin{tabular}{|c|c|c|c|c|c|c|}
\hline $\begin{array}{c}\mathrm{Su} \\
\mathrm{b}\end{array}$ & $\begin{array}{l}\mathrm{Te} \\
\mathrm{mp}\end{array}$ & $\begin{array}{l}\text { Humi } \\
\text { dity }\end{array}$ & $\begin{array}{c}\text { Exertio } \\
\mathrm{n}\end{array}$ & $\begin{array}{c}\text { Skin } \\
\text { Conductance } \\
\text { Mean }\end{array}$ & $\begin{array}{l}\text { Skin Conductance } \\
\text { Median }\end{array}$ & $\begin{array}{c}\text { Normalized Skin } \\
\text { Conductance }\end{array}$ \\
\hline 1 & $\begin{array}{c}65- \\
75\end{array}$ & $35-45$ & $\begin{array}{c}\text { No } \\
\text { exertion }\end{array}$ & 0.164584522 & 0.179967 & -0.043788074 \\
\hline 1 & $\begin{array}{l}65- \\
75 \\
\end{array}$ & $35-45$ & $\begin{array}{c}\text { No } \\
\text { exertion }\end{array}$ & 1.23561204 & 1.22847 & 0.270089934 \\
\hline 1 & $\begin{array}{l}65- \\
75\end{array}$ & $35-45$ & exertion & 0.277000163 & 0.278894 & -0.010843265 \\
\hline 1 & $\begin{array}{l}65- \\
75\end{array}$ & $35-45$ & exertion & 0.779048477 & 0.787514 & 0.136288272 \\
\hline 1 & $\begin{array}{l}65- \\
75\end{array}$ & $55-65$ & $\begin{array}{c}\text { No } \\
\text { exertion }\end{array}$ & 0.146797862 & 0.138894 & -0.049000678 \\
\hline 1 & $\begin{array}{l}65- \\
75\end{array}$ & $55-65$ & $\begin{array}{c}\text { No } \\
\text { exertion }\end{array}$ & 0.418633279 & 0.431376 & 0.030664091 \\
\hline 1 & $\begin{array}{l}65- \\
75\end{array}$ & $55-65$ & exertion & 0.71783337 & 0.71816 & 0.11834842 \\
\hline 1 & $\begin{array}{l}65- \\
75\end{array}$ & $55-65$ & exertion & 0.723059751 & 0.708116 & 0.119880076 \\
\hline 1 & $\begin{array}{l}85- \\
95\end{array}$ & $35-45$ & $\begin{array}{c}\text { No } \\
\text { exertion }\end{array}$ & 1.519278204 & 1.42038 & 0.353221851 \\
\hline 1 & $\begin{array}{c}85- \\
95 \\
\end{array}$ & $35-45$ & $\begin{array}{c}\text { No } \\
\text { exertion }\end{array}$ & 3.412241342 & 3.41177 & 0.907978373 \\
\hline 1 & $\begin{array}{l}85- \\
95\end{array}$ & $35-45$ & exertion & 0.324070228 & 0.323572 & 0.002951206 \\
\hline 1 & $\begin{array}{l}85- \\
95\end{array}$ & $35-45$ & exertion & 1.656604127 & 1.62861 & 0.39346693 \\
\hline 1 & $\begin{array}{c}85- \\
95\end{array}$ & $55-65$ & $\begin{array}{c}\text { No } \\
\text { exertion }\end{array}$ & 1.361354907 & 1.37948 & 0.306940454 \\
\hline 1 & $\begin{array}{c}85- \\
95 \\
\end{array}$ & $55-65$ & $\begin{array}{c}\text { No } \\
\text { exertion }\end{array}$ & 2.104832988 & 2.11546 & 0.524826004 \\
\hline 1 & $\begin{array}{c}85- \\
95 \\
\end{array}$ & $55-65$ & exertion & 0.926489702 & 0.94154 & 0.179497767 \\
\hline 1 & $\begin{array}{l}85- \\
95\end{array}$ & $55-65$ & exertion & 1.724169105 & 1.67228 & 0.413267692 \\
\hline 2 & $\begin{array}{c}65- \\
75 \\
\end{array}$ & $35-45$ & $\begin{array}{c}\text { No } \\
\text { exertion }\end{array}$ & 0.703314987 & 0.69975 & -0.140026654 \\
\hline 2 & $\begin{array}{l}65- \\
75 \\
\end{array}$ & $35-45$ & $\begin{array}{c}\text { No } \\
\text { exertion }\end{array}$ & 0.594237488 & 0.596075 & -0.17758338 \\
\hline 2 & $\begin{array}{l}65- \\
75 \\
\end{array}$ & $35-45$ & exertion & 2.656030664 & 2.63631 & 0.532317382 \\
\hline
\end{tabular}




\begin{tabular}{|c|c|c|c|c|c|c|}
2 & $\begin{array}{c}65- \\
75\end{array}$ & $35-45$ & exertion & 0.998396315 & 1.002 & -0.038426522 \\
\hline 2 & $\begin{array}{c}65- \\
75\end{array}$ & $55-65$ & $\begin{array}{c}\text { No } \\
\text { exertion }\end{array}$ & 0.83373222 & 0.834024 & -0.095122396 \\
\hline 2 & $\begin{array}{c}65- \\
75\end{array}$ & $55-65$ & $\begin{array}{c}\text { No } \\
\text { exertion }\end{array}$ & 0.669457936 & 0.666342 & -0.151684053 \\
\hline 2 & $\begin{array}{c}65- \\
75\end{array}$ & $55-65$ & exertion & 2.368402462 & 2.37398 & 0.433283453 \\
\hline 2 & $\begin{array}{c}65- \\
75\end{array}$ & $55-65$ & exertion & 2.90434 & 2.914541731 & 0.617813341 \\
\hline 2 & $\begin{array}{c}85- \\
95\end{array}$ & $35-45$ & $\begin{array}{c}\text { No } \\
\text { exertion }\end{array}$ & 0.419414278 & 0.428631 & -0.237777162 \\
\hline 2 & $\begin{array}{c}85- \\
95\end{array}$ & $35-45$ & $\begin{array}{c}\text { No } \\
\text { exertion }\end{array}$ & 0.520411799 & 0.539572 & -0.203002472 \\
\hline 2 & $\begin{array}{c}85- \\
95\end{array}$ & $35-45$ & exertion & 1.075692912 & 1.08788 & -0.011812353 \\
\hline 2 & $\begin{array}{c}85- \\
95\end{array}$ & $35-45$ & exertion & 2.233704998 & 2.19117 & 0.386905458 \\
\hline 2 & $\begin{array}{c}85- \\
95\end{array}$ & $55-65$ & $\begin{array}{c}\text { No } \\
\text { exertion }\end{array}$ & 0.499749347 & 0.506092 & -0.210116809 \\
\hline 2 & $\begin{array}{c}85- \\
95\end{array}$ & $55-65$ & $\begin{array}{c}\text { No } \\
\text { exertion }\end{array}$ & 1.338248472 & 1.31682 & 0.078588758 \\
\hline 2 & $\begin{array}{c}85- \\
95\end{array}$ & $55-65$ & exertion & 0.966854331 & 0.96177 & -0.049286815 \\
\hline 2 & $\begin{array}{c}85- \\
95\end{array}$ & $55-65$ & exertion & 2.098120882 & 2.07146 & 0.340222178 \\
\hline 3 & $\begin{array}{c}65- \\
75\end{array}$ & $35-45$ & $\begin{array}{c}\text { No } \\
\text { exertion }\end{array}$ & 2.420691414 & 2.44168 & 0.046449893 \\
\hline 3 & $\begin{array}{c}65- \\
75\end{array}$ & $35-45$ & $\begin{array}{c}\text { No } \\
\text { exertion }\end{array}$ & 1.793868269 & 1.7448 & -0.134741293 \\
\hline 3 & $\begin{array}{c}65- \\
75\end{array}$ & $35-45$ & exertion & 2.847800089 & 2.8395 & 0.169911077 \\
\hline 3 & $\begin{array}{c}65- \\
75\end{array}$ & $35-45$ & exertion & 2.750962845 & 2.71322 & 0.141919042 \\
\hline 3 & $\begin{array}{c}65- \\
75\end{array}$ & $55-65$ & $\begin{array}{c}\text { No } \\
\text { exertion }\end{array}$ & 1.667320307 & 1.66234 & -0.171321588 \\
\hline 3 & $\begin{array}{c}65- \\
75\end{array}$ & $55-65$ & $\begin{array}{c}\text { No } \\
\text { exertion }\end{array}$ & 2.830340833 & 2.81692 & 0.164864257 \\
\hline 3 & $\begin{array}{c}65- \\
75\end{array}$ & $55-65$ & exertion & 2.827666647 & 2.83988 & 0.16409125 \\
\hline 3 & $\begin{array}{c}65- \\
75\end{array}$ & $55-65$ & exertion & 2.25281041 & 2.25008 & -0.002078242 \\
\hline 3 & $\begin{array}{c}85- \\
95\end{array}$ & $35-45$ & $\begin{array}{c}\text { No } \\
\text { exertion }\end{array}$ & 3.227443636 & 3.22906 & 0.279651863 \\
\hline
\end{tabular}




\begin{tabular}{|c|c|c|c|c|c|c|}
\hline 3 & $\begin{array}{c}85- \\
95\end{array}$ & $35-45$ & $\begin{array}{c}\text { No } \\
\text { exertion }\end{array}$ & 2.498994819 & 2.47997 & 0.069084486 \\
\hline 3 & $\begin{array}{c}85- \\
95\end{array}$ & $35-45$ & exertion & 2.626236379 & 2.62411 & 0.105865274 \\
\hline 3 & $\begin{array}{c}85- \\
95\end{array}$ & $35-45$ & exertion & 3.459457147 & 3.46638 & 0.346718313 \\
\hline 3 & $\begin{array}{c}85- \\
95\end{array}$ & $55-65$ & $\begin{array}{c}\text { No } \\
\text { exertion }\end{array}$ & 3.409929359 & 3.39805 & 0.332401678 \\
\hline 3 & $\begin{array}{c}85- \\
95\end{array}$ & $55-65$ & $\begin{array}{c}\text { No } \\
\text { exertion }\end{array}$ & 1.976483497 & 1.96351 & -0.081954044 \\
\hline 3 & $\begin{array}{c}85- \\
95\end{array}$ & $55-65$ & exertion & 2.557233566 & 2.5444 & 0.085919135 \\
\hline 3 & $\begin{array}{c}85- \\
95\end{array}$ & $55-65$ & exertion & 3.321370071 & 3.296 & 0.306802491 \\
\hline 4 & $\begin{array}{c}65- \\
75\end{array}$ & $35-45$ & $\begin{array}{c}\text { No } \\
\text { exertion }\end{array}$ & 0.297511442 & 0.299143 & -0.749266452 \\
\hline 4 & $\begin{array}{c}65- \\
75\end{array}$ & $35-45$ & $\begin{array}{c}\text { No } \\
\text { exertion }\end{array}$ & 0.465357561 & 0.481404 & -0.648857179 \\
\hline 4 & $\begin{array}{c}65- \\
75\end{array}$ & $35-45$ & exertion & 1.234492214 & 1.23433 & -0.18874376 \\
\hline 4 & $\begin{array}{c}65- \\
75\end{array}$ & $35-45$ & exertion & 0.872771483 & 0.898151 & -0.405133129 \\
\hline 4 & $\begin{array}{c}65- \\
75\end{array}$ & $55-65$ & $\begin{array}{c}\text { No } \\
\text { exertion }\end{array}$ & 0.576496059 & 0.58183 & -0.582371663 \\
\hline 4 & $\begin{array}{c}65- \\
75\end{array}$ & $55-65$ & $\begin{array}{c}\text { No } \\
\text { exertion }\end{array}$ & 0.416022776 & 0.427589 & -0.678370343 \\
\hline 4 & $\begin{array}{c}65- \\
75\end{array}$ & $55-65$ & exertion & 1.509893296 & 1.50032 & -0.02399272 \\
\hline 4 & $\begin{array}{c}65- \\
75\end{array}$ & $55-65$ & exertion & 1.124391138 & 1.1271 & -0.254608667 \\
\hline 4 & $\begin{array}{c}85- \\
95\end{array}$ & $35-45$ & $\begin{array}{c}\text { No } \\
\text { exertion }\end{array}$ & 0.162713888 & 0.141385 & -0.829905341 \\
\hline 4 & $\begin{array}{c}85- \\
95\end{array}$ & $35-45$ & $\begin{array}{c}\text { No } \\
\text { exertion }\end{array}$ & 0.16698938 & 0.166886 & -0.827347647 \\
\hline 4 & $\begin{array}{c}85- \\
95\end{array}$ & $35-45$ & exertion & 0.672123528 & 0.6963 & -0.525165189 \\
\hline 4 & $\begin{array}{c}85- \\
95\end{array}$ & $35-45$ & exertion & 1.671619694 & 1.68475 & 0.0727556 \\
\hline 4 & $\begin{array}{c}85- \\
95\end{array}$ & $55-65$ & $\begin{array}{c}\text { No } \\
\text { exertion }\end{array}$ & 0.399329756 & 0.413205 & -0.688356477 \\
\hline 4 & $\begin{array}{c}85- \\
95\end{array}$ & $55-65$ & $\begin{array}{c}\text { No } \\
\text { exertion }\end{array}$ & 0.660036697 & 0.677425 & -0.532395799 \\
\hline 4 & $\begin{array}{c}85- \\
95\end{array}$ & $55-65$ & exertion & 1.355709567 & 1.36002 & -0.16228849 \\
\hline
\end{tabular}




\begin{tabular}{|c|c|c|c|c|c|c|}
\hline 4 & $\begin{array}{c}85- \\
95\end{array}$ & $55-65$ & exertion & 1.595182751 & 1.59533 & 0.027029324 \\
\hline 5 & $\begin{array}{c}65- \\
75\end{array}$ & $35-45$ & $\begin{array}{c}\text { No } \\
\text { exertion }\end{array}$ & 0.156891329 & 0.163812 & -0.254350825 \\
\hline 5 & $\begin{array}{c}65- \\
75\end{array}$ & $35-45$ & $\begin{array}{c}\text { No } \\
\text { exertion }\end{array}$ & 0.113780643 & 0.104764 & -0.286216451 \\
\hline 5 & $\begin{array}{c}65- \\
75\end{array}$ & $35-45$ & exertion & 0.112889822 & 0.113086 & -0.286874909 \\
\hline 5 & $\begin{array}{c}65- \\
75\end{array}$ & $35-45$ & exertion & 0.246472743 & 0.245292 & -0.188135967 \\
\hline 5 & $\begin{array}{c}65- \\
75\end{array}$ & $55-65$ & $\begin{array}{c}\text { No } \\
\text { exertion }\end{array}$ & 1.116227473 & 1.12374 & 0.454750572 \\
\hline 5 & $\begin{array}{c}65- \\
75\end{array}$ & $55-65$ & $\begin{array}{c}\text { No } \\
\text { exertion }\end{array}$ & 0.257630584 & 0.254806 & -0.179888555 \\
\hline 5 & $\begin{array}{c}65- \\
75\end{array}$ & $55-65$ & exertion & 1.146701707 & 1.1447 & 0.477275859 \\
\hline 5 & $\begin{array}{c}65- \\
75\end{array}$ & $55-65$ & exertion & 0.394200568 & 0.392826 & -0.0789417 \\
\hline 5 & $\begin{array}{c}85- \\
95\end{array}$ & $35-45$ & $\begin{array}{c}\text { No } \\
\text { exertion }\end{array}$ & 0.481938442 & 0.486765 & -0.014089512 \\
\hline 5 & $\begin{array}{c}85- \\
95\end{array}$ & $35-45$ & $\begin{array}{c}\text { No } \\
\text { exertion }\end{array}$ & 0.704929655 & 0.696676 & 0.150736323 \\
\hline 5 & $\begin{array}{c}85- \\
95\end{array}$ & $35-45$ & exertion & 0.321008061 & 0.321554 & -0.133042559 \\
\hline 5 & $\begin{array}{c}85- \\
95\end{array}$ & $35-45$ & exertion & 0.871807288 & 0.869478 & 0.274085333 \\
\hline 5 & $\begin{array}{c}85- \\
95\end{array}$ & $55-65$ & $\begin{array}{c}\text { No } \\
\text { exertion }\end{array}$ & 0.315472355 & 0.31253 & -0.137134322 \\
\hline 5 & $\begin{array}{c}85- \\
95\end{array}$ & $55-65$ & $\begin{array}{c}\text { No } \\
\text { exertion }\end{array}$ & 0.47854846 & 0.491987 & -0.016595245 \\
\hline 5 & $\begin{array}{c}85- \\
95\end{array}$ & $55-65$ & exertion & 1.352889938 & 1.33993 & 0.629681627 \\
\hline 5 & $\begin{array}{c}85- \\
95\end{array}$ & $55-65$ & exertion & 0.724283835 & 0.736756 & 0.165042128 \\
\hline 7 & $\begin{array}{c}65- \\
75\end{array}$ & $35-45$ & $\begin{array}{c}\text { No } \\
\text { exertion }\end{array}$ & 0.08682926 & 0.100532 & -0.487658331 \\
\hline 7 & $\begin{array}{c}65- \\
75\end{array}$ & $35-45$ & $\begin{array}{c}\text { No } \\
\text { exertion }\end{array}$ & 0.108087586 & 0.110012 & -0.462072082 \\
\hline 7 & $\begin{array}{c}65- \\
75\end{array}$ & $35-45$ & exertion & 0.830849622 & 0.837201 & 0.40783508 \\
\hline 7 & $\begin{array}{c}65- \\
75\end{array}$ & $35-45$ & exertion & 0.12067269 & 0.12454 & -0.446924811 \\
\hline 7 & $\begin{array}{c}65- \\
75\end{array}$ & $55-65$ & $\begin{array}{c}\text { No } \\
\text { exertion }\end{array}$ & 0.399039507 & 0.411341 & -0.11886063 \\
\hline
\end{tabular}




\begin{tabular}{|c|c|c|c|c|c|c|}
\hline 7 & $\begin{array}{c}65- \\
75 \\
\end{array}$ & $55-65$ & $\begin{array}{c}\text { No } \\
\text { exertion }\end{array}$ & 0.424786579 & 0.44015 & -0.080897215 \\
\hline 7 & $\begin{array}{c}65- \\
75 \\
\end{array}$ & $55-65$ & exertion & 0.363010767 & 0.366666 & -0.155249795 \\
\hline 7 & $\begin{array}{c}65- \\
75 \\
\end{array}$ & $55-65$ & exertion & 0.294324355 & 0.2954 & -0.237919884 \\
\hline 7 & $\begin{array}{c}85- \\
95 \\
\end{array}$ & $35-45$ & $\begin{array}{c}\text { No } \\
\text { exertion }\end{array}$ & 0.115135107 & 0.120586 & -0.453589775 \\
\hline 7 & $\begin{array}{l}85- \\
95 \\
\end{array}$ & $35-45$ & $\begin{array}{c}\text { No } \\
\text { exertion }\end{array}$ & 0.08538849 & 0.0997876 & -0.489392424 \\
\hline 7 & $\begin{array}{l}85- \\
95\end{array}$ & $35-45$ & exertion & 0.284640626 & 0.289626 & -0.249575096 \\
\hline 7 & $\begin{array}{l}85- \\
95 \\
\end{array}$ & $35-45$ & exertion & 0.422750143 & 0.427635 & -0.083348244 \\
\hline 7 & $\begin{array}{l}85- \\
95 \\
\end{array}$ & $55-65$ & $\begin{array}{c}\text { No } \\
\text { exertion } \\
\end{array}$ & 0.304045974 & 0.306484 & -0.226219066 \\
\hline 7 & $\begin{array}{c}85- \\
95 \\
\end{array}$ & $55-65$ & $\begin{array}{c}\text { No } \\
\text { exertion } \\
\end{array}$ & 0.193198005 & 0.19898 & -0.359634268 \\
\hline 7 & $\begin{array}{c}85- \\
95 \\
\end{array}$ & $55-65$ & exertion & 0.236184193 & 0.24022 & -0.30789664 \\
\hline 7 & $\begin{array}{c}85- \\
95\end{array}$ & $55-65$ & exertion & 0.331667534 & 0.340594 & -0.19297411 \\
\hline 8 & $\begin{array}{l}65- \\
75 \\
\end{array}$ & $35-45$ & $\begin{array}{c}\text { No } \\
\text { exertion }\end{array}$ & 0.701894106 & 0.702758 & -0.230545477 \\
\hline 8 & $\begin{array}{c}65- \\
75 \\
\end{array}$ & $35-45$ & $\begin{array}{c}\text { No } \\
\text { exertion }\end{array}$ & 0.920954117 & 0.95062 & -0.120301764 \\
\hline 8 & $\begin{array}{c}65- \\
75 \\
\end{array}$ & $35-45$ & exertion & 1.398488193 & 1.40349 & 0.120021102 \\
\hline 8 & $\begin{array}{l}65- \\
75\end{array}$ & $35-45$ & exertion & 1.042290057 & 1.0472 & -0.059238476 \\
\hline 8 & $\begin{array}{l}65- \\
75 \\
\end{array}$ & $55-65$ & $\begin{array}{c}\text { No } \\
\text { exertion }\end{array}$ & 1.371289597 & 1.35957 & 0.106333189 \\
\hline 8 & $\begin{array}{c}65- \\
75 \\
\end{array}$ & $55-65$ & $\begin{array}{c}\text { No } \\
\text { exertion }\end{array}$ & 1.216965009 & 1.2152 & 0.028668099 \\
\hline 8 & $\begin{array}{l}65- \\
75\end{array}$ & $55-65$ & exertion & 1.478693683 & 1.49983 & 0.16038516 \\
\hline 8 & $\begin{array}{l}65- \\
75\end{array}$ & $55-65$ & exertion & 1.553105318 & 1.53507 & 0.197833414 \\
\hline 8 & $\begin{array}{l}85- \\
95 \\
\end{array}$ & $35-45$ & $\begin{array}{c}\text { No } \\
\text { exertion }\end{array}$ & 1.534353104 & 1.55682 & 0.188396212 \\
\hline 8 & $\begin{array}{c}85- \\
95 \\
\end{array}$ & $35-45$ & $\begin{array}{c}\text { No } \\
\text { exertion }\end{array}$ & 0.835294704 & 0.848399 & -0.163410553 \\
\hline 8 & $\begin{array}{l}85- \\
95 \\
\end{array}$ & $35-45$ & exertion & 1.003879405 & 1.00073 & -0.078568946 \\
\hline
\end{tabular}




\begin{tabular}{|c|c|c|c|c|c|c|}
8 & $\begin{array}{c}85- \\
95\end{array}$ & $35-45$ & exertion & 1.484899194 & 1.46426 & 0.163508133 \\
\hline 8 & $\begin{array}{c}85- \\
95\end{array}$ & $55-65$ & $\begin{array}{c}\text { No } \\
\text { exertion }\end{array}$ & 1.528389255 & 1.53185 & 0.185394856 \\
\hline 8 & $\begin{array}{c}85- \\
95\end{array}$ & $55-65$ & $\begin{array}{c}\text { No } \\
\text { exertion }\end{array}$ & 1.204291542 & 1.19776 & 0.022290075 \\
\hline 8 & $\begin{array}{c}85- \\
95\end{array}$ & $55-65$ & exertion & 1.987052187 & 1.95144 & 0.416220667 \\
\hline 8 & $\begin{array}{c}85- \\
95\end{array}$ & $55-65$ & exertion & 1.106490873 & 1.11386 & -0.026928899 \\
\hline 9 & $\begin{array}{c}65- \\
75\end{array}$ & $35-45$ & $\begin{array}{c}\text { No } \\
\text { exertion }\end{array}$ & 1.076324143 & 1.08155 & 0.079930495 \\
\hline 9 & $\begin{array}{c}65- \\
75\end{array}$ & $35-45$ & $\begin{array}{c}\text { No } \\
\text { exertion }\end{array}$ & 0.838485691 & 0.821031 & -0.031031947 \\
\hline 9 & $\begin{array}{c}65- \\
75\end{array}$ & $35-45$ & exertion & 1.494187195 & 1.55533 & 0.274882591 \\
\hline 9 & $\begin{array}{c}65- \\
75\end{array}$ & $35-45$ & exertion & 0.563126063 & 0.564809 & -0.159499721 \\
\hline 9 & $\begin{array}{c}65- \\
75\end{array}$ & $55-65$ & $\begin{array}{c}\text { No } \\
\text { exertion }\end{array}$ & 1.401198586 & 1.3228 & 0.231499181 \\
\hline 9 & $\begin{array}{c}65- \\
75\end{array}$ & $55-65$ & $\begin{array}{c}\text { No } \\
\text { exertion }\end{array}$ & 0.531569179 & 0.534293 & -0.174222441 \\
\hline 9 & $\begin{array}{c}65- \\
75\end{array}$ & $55-65$ & exertion & 1.123223485 & 1.12219 & 0.101811169 \\
\hline 9 & $\begin{array}{c}65- \\
75\end{array}$ & $55-65$ & exertion & 0.961406865 & 0.968139 & 0.026316365 \\
\hline 9 & $\begin{array}{c}85- \\
95\end{array}$ & $35-45$ & $\begin{array}{c}\text { No } \\
\text { exertion }\end{array}$ & 2.119559723 & 2.11646 & 0.566647283 \\
\hline 9 & $\begin{array}{c}85- \\
95\end{array}$ & $35-45$ & $\begin{array}{c}\text { No } \\
\text { exertion }\end{array}$ & 1.916205036 & 1.9108 & 0.471773084 \\
\hline 9 & $\begin{array}{c}85- \\
95\end{array}$ & $35-45$ & exertion & 1.288711121 & 1.29118 & 0.179018668 \\
\hline 9 & $\begin{array}{c}85- \\
95\end{array}$ & $35-45$ & exertion & 1.105437995 & 1.11387 & 0.09351343 \\
\hline 9 & $\begin{array}{c}85- \\
95\end{array}$ & $55-65$ & $\begin{array}{c}\text { No } \\
\text { exertion }\end{array}$ & 2.092314683 & 2.09156 & 0.553936234 \\
\hline 9 & $\begin{array}{c}85- \\
95\end{array}$ & $55-65$ & $\begin{array}{c}\text { No } \\
\text { exertion }\end{array}$ & 2.143414007 & 2.14305 & 0.57777639 \\
\hline 9 & $\begin{array}{c}85- \\
95\end{array}$ & $55-65$ & exertion & 0.809297412 & 0.812256 & -0.044649605 \\
\hline 9 & $\begin{array}{c}85- \\
95\end{array}$ & $55-65$ & exertion & 1.474754239 & 1.48073 & 0.265816234 \\
\hline 10 & $\begin{array}{c}65- \\
75\end{array}$ & $35-45$ & $\begin{array}{c}\text { No } \\
\text { exertion }\end{array}$ & 0.149345348 & 0.15169 & -0.4304003 \\
\hline
\end{tabular}




\begin{tabular}{|c|c|c|c|c|c|c|}
\hline 10 & $\begin{array}{c}65- \\
75\end{array}$ & $35-45$ & $\begin{array}{c}\text { No } \\
\text { exertion }\end{array}$ & 0.069662739 & 0.0702098 & -0.471298971 \\
\hline 10 & $\begin{array}{c}65- \\
75\end{array}$ & $35-45$ & exertion & 0.726875616 & 0.725525 & -0.134744356 \\
\hline 10 & $\begin{array}{c}65- \\
75\end{array}$ & $35-45$ & exertion & 0.311317029 & 0.321655 & -0.347549316 \\
\hline 10 & $\begin{array}{c}65- \\
75\end{array}$ & $55-65$ & $\begin{array}{c}\text { No } \\
\text { exertion }\end{array}$ & 0.38666191 & 0.395411 & -0.308965672 \\
\hline 10 & $\begin{array}{c}65- \\
75\end{array}$ & $55-65$ & $\begin{array}{c}\text { No } \\
\text { exertion }\end{array}$ & 0.214791274 & 0.218201 & -0.396979553 \\
\hline 10 & $\begin{array}{c}65- \\
75\end{array}$ & $55-65$ & exertion & 0.673409204 & 0.674984 & -0.162124172 \\
\hline 10 & $\begin{array}{c}65- \\
75\end{array}$ & $55-65$ & exertion & 0.775978997 & 0.774798 & -0.109598821 \\
\hline 10 & $\begin{array}{c}85- \\
95\end{array}$ & $35-45$ & $\begin{array}{c}\text { No } \\
\text { exertion }\end{array}$ & 0.763554853 & 0.785221 & -0.115961147 \\
\hline 10 & $\begin{array}{c}85- \\
95\end{array}$ & $35-45$ & $\begin{array}{c}\text { No } \\
\text { exertion }\end{array}$ & 0.260158559 & 0.267397 & -0.373747249 \\
\hline 10 & $\begin{array}{c}85- \\
95\end{array}$ & $35-45$ & exertion & 0.990222099 & 0.993001 & 0.000113736 \\
\hline 10 & $\begin{array}{c}85- \\
95\end{array}$ & $35-45$ & exertion & 1.530464149 & 1.53878 & 0.276768319 \\
\hline 10 & $\begin{array}{c}85- \\
95\end{array}$ & $55-65$ & $\begin{array}{c}\text { No } \\
\text { exertion }\end{array}$ & 0.322252107 & 0.328254 & -0.34194953 \\
\hline 10 & $\begin{array}{c}85- \\
95\end{array}$ & $55-65$ & $\begin{array}{c}\text { No } \\
\text { exertion }\end{array}$ & 0.446460148 & 0.449958 & -0.278343368 \\
\hline 10 & $\begin{array}{c}85- \\
95\end{array}$ & $55-65$ & exertion & 1.69151071 & 1.67712 & 0.359239259 \\
\hline 10 & $\begin{array}{c}85- \\
95\end{array}$ & $55-65$ & exertion & 1.952767392 & 1.98938 & 0.493027176 \\
\hline 11 & $\begin{array}{c}65- \\
75\end{array}$ & $35-45$ & $\begin{array}{c}\text { No } \\
\text { exertion }\end{array}$ & 0.18253886 & 0.186579 & -0.211355262 \\
\hline 11 & $\begin{array}{c}65- \\
75\end{array}$ & $35-45$ & $\begin{array}{c}\text { No } \\
\text { exertion }\end{array}$ & 0.129349947 & 0.131043 & -0.239081116 \\
\hline 11 & $\begin{array}{c}65- \\
75\end{array}$ & $35-45$ & exertion & 0.571581076 & 0.578744 & -0.008558714 \\
\hline 11 & $\begin{array}{c}65- \\
75\end{array}$ & $35-45$ & exertion & 0.739148471 & 0.744139 & 0.078789362 \\
\hline 11 & $\begin{array}{c}65- \\
75\end{array}$ & $55-65$ & $\begin{array}{c}\text { No } \\
\text { exertion }\end{array}$ & 0.433327605 & 0.439302 & -0.080626282 \\
\hline 11 & $\begin{array}{c}65- \\
75\end{array}$ & $55-65$ & $\begin{array}{c}\text { No } \\
\text { exertion }\end{array}$ & 0.144295757 & 0.151793 & -0.231290294 \\
\hline 11 & $\begin{array}{c}65- \\
75\end{array}$ & $55-65$ & exertion & 0.825940221 & 0.826887 & 0.124031412 \\
\hline
\end{tabular}




\begin{tabular}{|c|c|c|c|c|c|c|}
11 & $\begin{array}{c}65- \\
75\end{array}$ & $55-65$ & exertion & 0.522680265 & 0.526595 & -0.034049304 \\
\hline 11 & $\begin{array}{c}85- \\
95\end{array}$ & $35-45$ & $\begin{array}{c}\text { No } \\
\text { exertion }\end{array}$ & 0.105460459 & 0.112117 & -0.251534021 \\
\hline 11 & $\begin{array}{c}85- \\
95\end{array}$ & $35-45$ & $\begin{array}{c}\text { No } \\
\text { exertion }\end{array}$ & 0.356120167 & 0.368852 & -0.120872305 \\
\hline 11 & $\begin{array}{c}85- \\
95\end{array}$ & $35-45$ & exertion & 0.434589437 & 0.442629 & -0.079968526 \\
\hline 11 & $\begin{array}{c}85- \\
95\end{array}$ & $35-45$ & exertion & 1.466358058 & 1.46944 & 0.45786286 \\
\hline 11 & $\begin{array}{c}85- \\
95\end{array}$ & $55-65$ & $\begin{array}{c}\text { No } \\
\text { exertion }\end{array}$ & 0.511949138 & 0.511936 & -0.039643133 \\
\hline 11 & $\begin{array}{c}85- \\
95\end{array}$ & $55-65$ & $\begin{array}{c}\text { No } \\
\text { exertion }\end{array}$ & 0.440622906 & 0.442756 & -0.076823452 \\
\hline 11 & $\begin{array}{c}85- \\
95\end{array}$ & $55-65$ & exertion & 0.735134999 & 0.744382 & 0.076697254 \\
\hline 11 & $\begin{array}{c}85- \\
95\end{array}$ & $55-65$ & exertion & 1.918386782 & 2.06761 & 0.693492467 \\
\hline 12 & $\begin{array}{c}65- \\
75\end{array}$ & $35-45$ & $\begin{array}{c}\text { No } \\
\text { exertion }\end{array}$ & 0.065221192 & 0.0702473 & -0.427982098 \\
\hline 12 & $\begin{array}{c}65- \\
75\end{array}$ & $35-45$ & $\begin{array}{c}\text { No } \\
\text { exertion }\end{array}$ & 0.008526091 & 0.0125067 & -0.51825889 \\
\hline 12 & $\begin{array}{c}65- \\
75\end{array}$ & $35-45$ & exertion & 0.128742457 & 0.131254 & -0.326835864 \\
\hline 12 & $\begin{array}{c}65- \\
75\end{array}$ & $35-45$ & exertion & 0.111607777 & 0.115113 & -0.354119773 \\
\hline 12 & $\begin{array}{c}65- \\
75\end{array}$ & $55-65$ & $\begin{array}{c}\text { No } \\
\text { exertion }\end{array}$ & 0.078063742 & 0.0793152 & -0.407532638 \\
\hline 12 & $\begin{array}{c}65- \\
75\end{array}$ & $55-65$ & $\begin{array}{c}\text { No } \\
\text { exertion }\end{array}$ & 0.442199495 & 0.447842 & 0.172288312 \\
\hline 12 & $\begin{array}{c}65- \\
75\end{array}$ & $55-65$ & exertion & 0.346038221 & 0.345597 & 0.019168711 \\
\hline 12 & $\begin{array}{c}65- \\
75\end{array}$ & $55-65$ & exertion & 0.220833216 & 0.228214 & -0.180197829 \\
\hline 12 & $\begin{array}{c}85- \\
95\end{array}$ & $35-45$ & $\begin{array}{c}\text { No } \\
\text { exertion }\end{array}$ & 0.057328539 & 0.0699587 & -0.440549736 \\
\hline 12 & $\begin{array}{c}85- \\
95\end{array}$ & $35-45$ & $\begin{array}{c}\text { No } \\
\text { exertion }\end{array}$ & 0.180252502 & 0.182931 & -0.244815346 \\
\hline 12 & $\begin{array}{c}85- \\
95\end{array}$ & $35-45$ & exertion & 0.202222273 & 0.210293 & -0.209832422 \\
\hline 12 & $\begin{array}{c}85- \\
95\end{array}$ & $35-45$ & exertion & 0.628014136 & 0.643105 & 0.468164838 \\
\hline 12 & $\begin{array}{c}85- \\
95\end{array}$ & $55-65$ & $\begin{array}{c}\text { No } \\
\text { exertion }\end{array}$ & 0.09802256 & 0.102647 & -0.375751796 \\
\hline
\end{tabular}




\begin{tabular}{|c|c|c|c|c|c|c|}
12 & $\begin{array}{c}85- \\
95\end{array}$ & $55-65$ & $\begin{array}{c}\text { No } \\
\text { exertion }\end{array}$ & 0.29633586 & 0.31289 & -0.059973395 \\
\hline 12 & $\begin{array}{c}85- \\
95\end{array}$ & $55-65$ & exertion & 0.409429039 & 0.41801 & 0.120107232 \\
\hline 12 & $\begin{array}{c}85- \\
95\end{array}$ & $55-65$ & exertion & 0.585327076 & 0.596904 & 0.400193343 \\
\hline 13 & $\begin{array}{c}65- \\
75\end{array}$ & $35-45$ & $\begin{array}{c}\text { No } \\
\text { exertion }\end{array}$ & 0.060884107 & 0.0646368 & -1.027123534 \\
\hline 13 & $\begin{array}{c}65- \\
75\end{array}$ & $35-45$ & $\begin{array}{c}\text { No } \\
\text { exertion }\end{array}$ & 0.403793518 & 0.418788 & -0.700735675 \\
\hline 13 & $\begin{array}{c}65- \\
75\end{array}$ & $35-45$ & exertion & 0.694807248 & 0.699013 & -0.423743136 \\
\hline 13 & $\begin{array}{c}65- \\
75\end{array}$ & $35-45$ & exertion & 0.426673615 & 0.439045 & -0.678957953 \\
\hline 13 & $\begin{array}{c}65- \\
75\end{array}$ & $55-65$ & $\begin{array}{c}\text { No } \\
\text { exertion }\end{array}$ & 0.777796594 & 0.785118 & -0.344752259 \\
\hline 13 & $\begin{array}{c}65- \\
75\end{array}$ & $55-65$ & $\begin{array}{c}\text { No } \\
\text { exertion }\end{array}$ & 0.066778566 & 0.0651843 & -1.021513073 \\
\hline 13 & $\begin{array}{c}65- \\
75\end{array}$ & $55-65$ & exertion & 1.050619382 & 1.04826 & -0.085074214 \\
\hline 13 & $\begin{array}{c}65- \\
75\end{array}$ & $55-65$ & exertion & 0.916819262 & 0.916794 & -0.212427775 \\
\hline 13 & $\begin{array}{c}85- \\
95\end{array}$ & $35-45$ & $\begin{array}{c}\text { No } \\
\text { exertion }\end{array}$ & 0.056430586 & 0.0578958 & -1.031362482 \\
\hline 13 & $\begin{array}{c}85- \\
95\end{array}$ & $35-45$ & $\begin{array}{c}\text { No } \\
\text { exertion }\end{array}$ & 0.213060134 & 0.211609 & -0.882279426 \\
\hline 13 & $\begin{array}{c}85- \\
95\end{array}$ & $35-45$ & exertion & 0.512491372 & 0.533654 & -0.59727494 \\
\hline 13 & $\begin{array}{c}85- \\
95\end{array}$ & $35-45$ & exertion & 0.265641893 & 0.275887 & -0.832231084 \\
\hline 13 & $\begin{array}{c}85- \\
95\end{array}$ & $55-65$ & $\begin{array}{c}\text { No } \\
\text { exertion }\end{array}$ & 0.078348277 & 0.0860844 & -1.010500797 \\
\hline 13 & $\begin{array}{c}85- \\
95\end{array}$ & $55-65$ & $\begin{array}{c}\text { No } \\
\text { exertion }\end{array}$ & 0.143316522 & 0.149514 & -0.948662755 \\
\hline 13 & $\begin{array}{c}85- \\
95\end{array}$ & $55-65$ & exertion & 0.985715387 & 0.985891 & -0.146851101 \\
\hline 13 & $\begin{array}{c}85- \\
95\end{array}$ & $55-65$ & exertion & 0.516196671 & 0.522903 & -0.593748164 \\
\hline 14 & $\begin{array}{c}65- \\
75\end{array}$ & $35-45$ & $\begin{array}{c}\text { No } \\
\text { exertion }\end{array}$ & 0.11065915 & 0.112316 & -0.557865036 \\
\hline 14 & $\begin{array}{c}65- \\
75\end{array}$ & $35-45$ & $\begin{array}{c}\text { No } \\
\text { exertion }\end{array}$ & 0.104487757 & 0.109637 & -0.564213081 \\
\hline 14 & $\begin{array}{c}65- \\
75\end{array}$ & $35-45$ & exertion & 0.733326677 & 0.7554 & 0.08262598 \\
\hline
\end{tabular}




\begin{tabular}{|c|c|c|c|c|c|c|}
14 & $\begin{array}{c}65- \\
75\end{array}$ & $35-45$ & exertion & 0.287383049 & 0.296141 & -0.376082519 \\
\hline 14 & $\begin{array}{c}65- \\
75\end{array}$ & $55-65$ & $\begin{array}{c}\text { No } \\
\text { exertion }\end{array}$ & 0.972172148 & 0.966702 & 0.328308262 \\
\hline 14 & $\begin{array}{c}65- \\
75\end{array}$ & $55-65$ & $\begin{array}{c}\text { No } \\
\text { exertion }\end{array}$ & 0.16943394 & 0.179023 & -0.497407852 \\
\hline 14 & $\begin{array}{c}65- \\
75\end{array}$ & $55-65$ & exertion & 0.20465269 & 0.208595 & -0.461180986 \\
\hline 14 & $\begin{array}{c}65- \\
75\end{array}$ & $55-65$ & exertion & 0.302637978 & 0.307949 & -0.360390928 \\
\hline 14 & $\begin{array}{c}85- \\
95\end{array}$ & $35-45$ & $\begin{array}{c}\text { No } \\
\text { exertion }\end{array}$ & 0.081666561 & 0.0869639 & -0.58768752 \\
\hline 14 & $\begin{array}{c}85- \\
95\end{array}$ & $35-45$ & $\begin{array}{c}\text { No } \\
\text { exertion }\end{array}$ & 0.7838274 & 0.775499 & 0.134572257 \\
\hline 14 & $\begin{array}{c}85- \\
95\end{array}$ & $35-45$ & exertion & 0.243717581 & 0.244325 & -0.420997886 \\
\hline 14 & $\begin{array}{c}85- \\
95\end{array}$ & $35-45$ & exertion & 0.413416961 & 0.421389 & -0.246440962 \\
\hline 14 & $\begin{array}{c}85- \\
95\end{array}$ & $55-65$ & $\begin{array}{c}\text { No } \\
\text { exertion }\end{array}$ & 0.616154969 & 0.602555 & -0.037899698 \\
\hline 14 & $\begin{array}{c}85- \\
95\end{array}$ & $55-65$ & exertion & 0.232854717 & 0.243229 & -0.432171692 \\
\hline 14 & $\begin{array}{c}85- \\
95\end{array}$ & $55-65$ & exertion & 0.958167613 & 0.962215 & 0.313902856 \\
\hline 18 & $\begin{array}{c}65- \\
75\end{array}$ & $35-45$ & $\begin{array}{c}\text { No } \\
\text { exertion }\end{array}$ & 1.286349154 & 1.27299 & 0.2464679 \\
\hline 18 & $\begin{array}{c}65- \\
75\end{array}$ & $35-45$ & $\begin{array}{c}\text { No } \\
\text { exertion }\end{array}$ & 0.797881237 & 0.799757 & -0.052012115 \\
\hline 18 & $\begin{array}{c}65- \\
75\end{array}$ & $35-45$ & exertion & 1.547821859 & 1.49857 & 0.406241703 \\
\hline 18 & $\begin{array}{c}65- \\
75\end{array}$ & $35-45$ & exertion & 1.157445272 & 1.15396 & 0.167700736 \\
\hline 18 & $\begin{array}{c}65- \\
75\end{array}$ & $55-65$ & $\begin{array}{c}\text { No } \\
\text { exertion }\end{array}$ & 0.615635466 & 0.639107 & -0.163374026 \\
\hline 18 & $\begin{array}{c}65- \\
75\end{array}$ & $55-65$ & $\begin{array}{c}\text { No } \\
\text { exertion }\end{array}$ & 0.511964349 & 0.523645 & -0.226722622 \\
\hline 18 & $\begin{array}{c}65- \\
75\end{array}$ & $55-65$ & exertion & 1.636517998 & 1.60095 & 0.460439787 \\
\hline 18 & $\begin{array}{c}65- \\
75\end{array}$ & $55-65$ & exertion & 0.886530784 & 0.886006 & 0.002157498 \\
\hline 18 & $\begin{array}{c}85- \\
95\end{array}$ & $35-45$ & $\begin{array}{c}\text { No } \\
\text { exertion }\end{array}$ & 0.687110543 & 0.686414 & -0.119698932 \\
\hline 18 & $\begin{array}{c}85- \\
95\end{array}$ & $35-45$ & $\begin{array}{c}\text { No } \\
\text { exertion }\end{array}$ & 0.320431547 & 0.332767 & -0.343759405 \\
\hline
\end{tabular}




\begin{tabular}{|c|c|c|c|c|c|c|}
18 & $\begin{array}{c}85- \\
95\end{array}$ & $35-45$ & exertion & 1.101498839 & 1.10376 & 0.133514473 \\
\hline 18 & $\begin{array}{c}85- \\
95\end{array}$ & $35-45$ & exertion & 1.207267404 & 1.21109 & 0.198144722 \\
\hline 18 & $\begin{array}{c}85- \\
95\end{array}$ & $55-65$ & $\begin{array}{c}\text { No } \\
\text { exertion }\end{array}$ & 0.787687634 & 0.780282 & -0.058240952 \\
\hline 18 & $\begin{array}{c}85- \\
95\end{array}$ & $55-65$ & $\begin{array}{c}\text { No } \\
\text { exertion }\end{array}$ & 0.447351266 & 0.456553 & -0.26620467 \\
\hline 18 & $\begin{array}{c}85- \\
95\end{array}$ & $55-65$ & exertion & 1.200272123 & 1.18872 & 0.193870232 \\
\hline 18 & $\begin{array}{c}85- \\
95\end{array}$ & $55-65$ & exertion & 1.346741449 & 1.37415 & 0.283370821 \\
\hline 19 & $\begin{array}{c}65- \\
75\end{array}$ & $35-45$ & $\begin{array}{c}\text { No } \\
\text { exertion }\end{array}$ & 3.010080911 & 3.02436 & -0.37728113 \\
\hline 19 & $\begin{array}{c}65- \\
75\end{array}$ & $35-45$ & $\begin{array}{c}\text { No } \\
\text { exertion }\end{array}$ & 2.475379233 & 2.44491 & -0.4138938 \\
\hline 19 & $\begin{array}{c}65- \\
75\end{array}$ & $35-45$ & exertion & 9.070884666 & 9.00023 & 0.03772077 \\
\hline 19 & $\begin{array}{c}65- \\
75\end{array}$ & $35-45$ & exertion & 5.993451394 & 6.00865 & -0.173000564 \\
\hline 19 & $\begin{array}{c}65- \\
75\end{array}$ & $55-65$ & $\begin{array}{c}\text { No } \\
\text { exertion }\end{array}$ & 4.085958219 & 4.09244 & -0.303612497 \\
\hline 19 & $\begin{array}{c}65- \\
75\end{array}$ & $55-65$ & $\begin{array}{c}\text { No } \\
\text { exertion }\end{array}$ & 4.095600938 & 4.10475 & -0.30295223 \\
\hline 19 & $\begin{array}{c}65- \\
75\end{array}$ & $55-65$ & exertion & 5.108341814 & 5.09667 & -0.233606743 \\
\hline 19 & $\begin{array}{c}65- \\
75\end{array}$ & $55-65$ & exertion & 5.856320578 & 5.82311 & -0.182390334 \\
\hline 19 & $\begin{array}{c}85- \\
95\end{array}$ & $35-45$ & $\begin{array}{c}\text { No } \\
\text { exertion }\end{array}$ & 5.153369854 & 5.16722 & -0.230523535 \\
\hline 19 & $\begin{array}{c}85- \\
95\end{array}$ & $35-45$ & $\begin{array}{c}\text { No } \\
\text { exertion }\end{array}$ & 7.859402055 & 7.84386 & -0.045233176 \\
\hline 19 & $\begin{array}{c}85- \\
95\end{array}$ & $35-45$ & exertion & 9.972296152 & 10.0581 & 0.09944319 \\
\hline 19 & $\begin{array}{c}85- \\
95\end{array}$ & $35-45$ & exertion & 14.60427956 & 14.6353 & 0.41660936 \\
\hline 19 & $\begin{array}{c}85- \\
95\end{array}$ & $55-65$ & $\begin{array}{c}\text { No } \\
\text { exertion }\end{array}$ & 9.394223165 & 9.43067 & 0.059860753 \\
\hline 19 & $\begin{array}{c}85- \\
95\end{array}$ & $55-65$ & $\begin{array}{c}\text { No } \\
\text { exertion }\end{array}$ & 6.019225999 & 5.92167 & -0.171235698 \\
\hline 19 & $\begin{array}{c}85- \\
95\end{array}$ & $55-65$ & exertion & 8.907997496 & 8.77359 & 0.026567384 \\
\hline 19 & $\begin{array}{c}85- \\
95\end{array}$ & $55-65$ & exertion & 10.20382244 & 10.2177 & 0.115296509 \\
\hline
\end{tabular}




\begin{tabular}{|c|c|c|c|c|c|c|}
20 & $\begin{array}{c}65- \\
75\end{array}$ & $35-45$ & $\begin{array}{c}\text { No } \\
\text { exertion }\end{array}$ & 1.153466109 & 1.18762 & -0.18073403 \\
\hline 20 & $\begin{array}{c}65- \\
75\end{array}$ & $35-45$ & $\begin{array}{c}\text { No } \\
\text { exertion }\end{array}$ & 0.861948115 & 0.870381 & -0.233079234 \\
\hline 20 & $\begin{array}{c}65- \\
75\end{array}$ & $35-45$ & exertion & 2.309432566 & 2.29952 & 0.026832231 \\
\hline 20 & $\begin{array}{c}65- \\
75\end{array}$ & $35-45$ & exertion & 2.857549795 & 2.83879 & 0.125252599 \\
\hline 20 & $\begin{array}{c}65- \\
75\end{array}$ & $55-65$ & $\begin{array}{c}\text { No } \\
\text { exertion }\end{array}$ & 0.878441022 & 0.887886 & -0.230117755 \\
\hline 20 & $\begin{array}{c}65- \\
75\end{array}$ & $55-65$ & exertion & 3.69479419 & 3.66027 & 0.275588872 \\
\hline 20 & $\begin{array}{c}65- \\
75\end{array}$ & $55-65$ & exertion & 1.390554621 & 1.39156 & -0.138162227 \\
\hline 20 & $\begin{array}{c}85- \\
95\end{array}$ & $35-45$ & $\begin{array}{c}\text { No } \\
\text { exertion }\end{array}$ & 1.994413576 & 1.9976 & -0.029732831 \\
\hline 20 & $\begin{array}{c}85- \\
95\end{array}$ & $35-45$ & $\begin{array}{c}\text { No } \\
\text { exertion }\end{array}$ & 2.351664558 & 2.35065 & 0.034415441 \\
\hline 20 & $\begin{array}{c}85- \\
95\end{array}$ & $35-45$ & exertion & 2.297782298 & 2.27393 & 0.0247403 \\
\hline 20 & $\begin{array}{c}85- \\
95\end{array}$ & $35-45$ & exertion & 3.093602958 & 3.06913 & 0.167638493 \\
\hline 20 & $\begin{array}{c}85- \\
95\end{array}$ & $55-65$ & $\begin{array}{c}\text { No } \\
\text { exertion }\end{array}$ & 1.708431276 & 1.70498 & -0.081084041 \\
\hline 20 & $\begin{array}{c}85- \\
95\end{array}$ & $55-65$ & $\begin{array}{c}\text { No } \\
\text { exertion }\end{array}$ & 2.196893233 & 2.2122 & 0.006624578 \\
\hline 20 & $\begin{array}{c}85- \\
95\end{array}$ & $55-65$ & exertion & 2.641826697 & 2.61363 & 0.086517187 \\
\hline 20 & $\begin{array}{c}85- \\
95\end{array}$ & $55-65$ & exertion & 5.56914429 & 5.50554 & 0.612148674 \\
\hline 21 & $\begin{array}{c}65- \\
75\end{array}$ & $35-45$ & $\begin{array}{c}\text { No } \\
\text { exertion }\end{array}$ & 0.69462453 & 0.689417 & 0.109968314 \\
\hline 21 & $\begin{array}{c}65- \\
75\end{array}$ & $35-45$ & $\begin{array}{c}\text { No } \\
\text { exertion }\end{array}$ & 0.244290987 & 0.249279 & -0.091650068 \\
\hline 21 & $\begin{array}{c}65- \\
75\end{array}$ & $35-45$ & exertion & 0.938396127 & 0.937146 & 0.219107052 \\
\hline 21 & $\begin{array}{c}65- \\
75\end{array}$ & $35-45$ & exertion & 0.78501475 & 0.788641 & 0.150436829 \\
\hline 21 & $\begin{array}{c}65- \\
75\end{array}$ & $55-65$ & $\begin{array}{c}\text { No } \\
\text { exertion }\end{array}$ & 0.879176886 & 0.879319 & 0.192594065 \\
\hline 21 & $\begin{array}{c}65- \\
75\end{array}$ & $55-65$ & $\begin{array}{c}\text { No } \\
\text { exertion }\end{array}$ & 0.398039747 & 0.397642 & -0.022815364 \\
\hline 21 & $\begin{array}{c}65- \\
75\end{array}$ & $55-65$ & exertion & 0.583074821 & 0.579803 & 0.06505 \\
\hline
\end{tabular}




\begin{tabular}{|c|c|c|c|c|c|c|}
21 & $\begin{array}{c}65- \\
75\end{array}$ & $55-65$ & exertion & 0.79996425 & 0.796409 & 0.157129854 \\
\hline 21 & $\begin{array}{c}85- \\
95\end{array}$ & $35-45$ & $\begin{array}{c}\text { No } \\
\text { exertion }\end{array}$ & 1.239995332 & 1.21327 & 0.18445402 \\
\hline 21 & $\begin{array}{c}85- \\
95\end{array}$ & $35-45$ & $\begin{array}{c}\text { No } \\
\text { exertion }\end{array}$ & 1.13357875 & 1.11646 & 0.136810358 \\
\hline 21 & $\begin{array}{c}85- \\
95\end{array}$ & $35-45$ & exertion & 1.3253848 & 1.31388 & 0.222683653 \\
\hline 21 & $\begin{array}{c}85- \\
95\end{array}$ & $35-45$ & exertion & 2.233593677 & 2.22408 & 0.629296945 \\
\hline 21 & $\begin{array}{c}85- \\
95\end{array}$ & $55-65$ & $\begin{array}{c}\text { No } \\
\text { exertion }\end{array}$ & 1.612393075 & 1.60614 & 0.351179842 \\
\hline 21 & $\begin{array}{c}85- \\
95\end{array}$ & $55-65$ & $\begin{array}{c}\text { No } \\
\text { exertion }\end{array}$ & 1.513333333 & 1.48784 & 0.306829904 \\
\hline 21 & $\begin{array}{c}85- \\
95\end{array}$ & $55-65$ & exertion & 1.728704389 & 1.69861 & 0.403253465 \\
\hline 21 & $\begin{array}{c}85- \\
95\end{array}$ & $55-65$ & exertion & 2.118897362 & 2.0887 & 0.577946372 \\
\hline
\end{tabular}




\section{Appendix E: Blood Perfusion Data Table (No Exertion V.S. Exertion)}

\begin{tabular}{|c|c|c|c|c|c|}
\hline Subject & Exertion & Temp & Humidity & $\begin{array}{l}\text { Blood Perfusion } \\
\text { Mean }\end{array}$ & $\begin{array}{l}\text { Blood Perfusion } \\
\text { Median }\end{array}$ \\
\hline 1 & No & $\mathrm{L}$ & $\mathrm{L}$ & 154.9939971 & 139.618 \\
\hline 1 & No & $\mathrm{L}$ & $\mathrm{H}$ & 100.3992069 & 80.994 \\
\hline 1 & No & $\mathrm{H}$ & $\mathrm{L}$ & 77.90534048 & 52.979 \\
\hline 1 & No & $\mathrm{H}$ & $\mathrm{H}$ & 73.12306355 & 56.824 \\
\hline 1 & Yes & $\mathrm{L}$ & $\mathrm{L}$ & 98.83301137 & 80.536 \\
\hline 1 & Yes & $\mathrm{L}$ & $\mathrm{H}$ & 84.52699375 & 73.944 \\
\hline 1 & Yes & $\mathrm{H}$ & $\mathrm{L}$ & 111.8396696 & 85.236 \\
\hline 1 & Yes & $\mathrm{H}$ & $\mathrm{H}$ & 143.9562301 & 108.841 \\
\hline 2 & No & $\mathrm{L}$ & $\mathrm{L}$ & 52.89095691 & 39.963 \\
\hline 2 & No & $\mathrm{L}$ & $\mathrm{H}$ & 49.872777 & 27.985 \\
\hline 2 & No & $\mathrm{H}$ & $\mathrm{L}$ & 37.00655457 & 24.353 \\
\hline 2 & No & $\mathrm{H}$ & $\mathrm{H}$ & 34.21505869 & 20.752 \\
\hline 2 & Yes & $\mathrm{L}$ & $\mathrm{L}$ & 59.38091521 & 37.323 \\
\hline 2 & Yes & $\mathrm{L}$ & $\mathrm{H}$ & 79.94796533 & 35.034 \\
\hline 2 & Yes & $\mathrm{H}$ & $\mathrm{L}$ & 87.087724 & 55.817 \\
\hline 2 & Yes & $\mathrm{H}$ & $\mathrm{H}$ & 73.71683301 & 57.282 \\
\hline 3 & No & $\mathrm{L}$ & $\mathrm{L}$ & 43.76069656 & 35.126 \\
\hline 3 & No & L & $\mathrm{H}$ & 65.54915407 & 51.849 \\
\hline 3 & No & $\mathrm{H}$ & $\mathrm{L}$ & 81.05236314 & 75.455 \\
\hline 3 & No & $\mathrm{H}$ & $\mathrm{H}$ & 88.3258758 & 82.398 \\
\hline 3 & Yes & $\mathrm{L}$ & $\mathrm{L}$ & 63.54644725 & 41.504 \\
\hline 3 & Yes & $\mathrm{L}$ & $\mathrm{H}$ & 53.1515085 & 31.067 \\
\hline 3 & Yes & $\mathrm{H}$ & $\mathrm{L}$ & 72.80884257 & 56.366 \\
\hline 3 & Yes & $\mathrm{H}$ & $\mathrm{H}$ & 81.79559404 & 56.03 \\
\hline 4 & No & $\mathrm{L}$ & $\mathrm{L}$ & 163.8688487 & 170.838 \\
\hline 4 & No & $\mathrm{L}$ & $\mathrm{H}$ & 150.6683746 & 157.105 \\
\hline 4 & No & $\mathrm{H}$ & $\mathrm{L}$ & 187.2511054 & 151.55 \\
\hline 4 & No & $\mathrm{H}$ & $\mathrm{H}$ & 117.1790521 & 96.588 \\
\hline 4 & Yes & $\mathrm{L}$ & $\mathrm{L}$ & 130.8673647 & 127.319 \\
\hline 4 & Yes & $\mathrm{L}$ & $\mathrm{H}$ & 153.5701642 & 139.343 \\
\hline 4 & Yes & $\mathrm{H}$ & $\mathrm{L}$ & 138.7149203 & 128.784 \\
\hline 4 & Yes & $\mathrm{H}$ & $\mathrm{H}$ & 151.9707373 & 137.299 \\
\hline 5 & No & $\mathrm{L}$ & $\mathrm{L}$ & 65.79212508 & 60.333 \\
\hline 5 & No & $\mathrm{L}$ & $\mathrm{H}$ & 74.51463756 & 70.068 \\
\hline
\end{tabular}




\begin{tabular}{|c|c|c|c|c|c|}
\hline 5 & No & $\mathrm{H}$ & $\mathrm{L}$ & 53.34722133 & 37.781 \\
\hline 5 & No & $\mathrm{H}$ & $\mathrm{H}$ & 70.82675185 & 66.376 \\
\hline 5 & Yes & $\mathrm{L}$ & $\mathrm{L}$ & 74.02651188 & 39.887 \\
\hline 5 & Yes & $\mathrm{L}$ & $\mathrm{H}$ & 77.43879934 & 67.139 \\
\hline 5 & Yes & $\mathrm{H}$ & $\mathrm{L}$ & 90.80256823 & 53.833 \\
\hline 5 & Yes & $\mathrm{H}$ & $\mathrm{H}$ & 101.1587327 & 58.777 \\
\hline 7 & No & $\mathrm{L}$ & $\mathrm{L}$ & 46.21713883 & 55.206 \\
\hline 7 & No & $\mathrm{L}$ & $\mathrm{H}$ & 66.49093366 & 65.094 \\
\hline 7 & No & $\mathrm{H}$ & $\mathrm{L}$ & 120.2900656 & 117.828 \\
\hline 7 & No & $\mathrm{H}$ & $\mathrm{H}$ & 71.11128473 & 58.35 \\
\hline 7 & Yes & $\mathrm{L}$ & $\mathrm{L}$ & 59.59549832 & 49.927 \\
\hline 7 & Yes & $\mathrm{L}$ & $\mathrm{H}$ & 67.08339158 & 51.849 \\
\hline 7 & Yes & $\mathrm{H}$ & $\mathrm{L}$ & 55.64182557 & 46.6 \\
\hline 7 & Yes & $\mathrm{H}$ & $\mathrm{H}$ & 87.18475176 & 74.768 \\
\hline 8 & No & $\mathrm{L}$ & $\mathrm{L}$ & 17.77041129 & 15.625 \\
\hline 8 & No & $\mathrm{L}$ & $\mathrm{H}$ & 25.50745401 & 16.998 \\
\hline 8 & No & $\mathrm{H}$ & $\mathrm{L}$ & 16.72484584 & 14.526 \\
\hline 8 & No & $\mathrm{H}$ & $\mathrm{H}$ & 40.72178239 & 31.982 \\
\hline 8 & Yes & $\mathrm{L}$ & $\mathrm{L}$ & 42.51524815 & 30.396 \\
\hline 8 & Yes & $\mathrm{L}$ & $\mathrm{H}$ & 66.83453053 & 52.033 \\
\hline 8 & Yes & $\mathrm{H}$ & $\mathrm{L}$ & 39.81940429 & 33.112 \\
\hline 8 & Yes & $\mathrm{H}$ & $\mathrm{H}$ & 59.92137889 & 44.922 \\
\hline 9 & No & $\mathrm{L}$ & $\mathrm{L}$ & 40.14164869 & 35.461 \\
\hline 9 & No & L & $\mathrm{H}$ & 26.86612705 & 21.027 \\
\hline 9 & No & $\mathrm{H}$ & $\mathrm{L}$ & 39.3660109 & 37.994 \\
\hline 9 & No & $\mathrm{H}$ & $\mathrm{H}$ & 37.62232159 & 32.867 \\
\hline 9 & Yes & $\mathrm{L}$ & $\mathrm{L}$ & 100.0880289 & 78.1405 \\
\hline 9 & Yes & $\mathrm{L}$ & $\mathrm{H}$ & 64.18978348 & 44.495 \\
\hline 9 & Yes & $\mathrm{H}$ & $\mathrm{L}$ & 46.30522246 & 39.185 \\
\hline 9 & Yes & $\mathrm{H}$ & $\mathrm{H}$ & 45.73002428 & 37.872 \\
\hline 10 & No & L & $\mathrm{L}$ & 47.12583436 & 46.509 \\
\hline 10 & No & $\mathrm{L}$ & $\mathrm{H}$ & 52.4603427 & 50.507 \\
\hline 10 & No & $\mathrm{H}$ & $\mathrm{L}$ & 49.71451279 & 45.654 \\
\hline 10 & No & $\mathrm{H}$ & $\mathrm{H}$ & 105.2802405 & 91.004 \\
\hline 10 & Yes & $\mathrm{L}$ & $\mathrm{L}$ & 76.27482414 & 53.345 \\
\hline 10 & Yes & $\mathrm{L}$ & $\mathrm{H}$ & 105.6563781 & 89.203 \\
\hline 10 & Yes & $\mathrm{H}$ & $\mathrm{L}$ & 98.65382486 & 80.292 \\
\hline 10 & Yes & $\mathrm{H}$ & $\mathrm{H}$ & 97.55771864 & 76.355 \\
\hline 11 & No & $\mathrm{L}$ & $\mathrm{L}$ & 60.79358894 & 55.786 \\
\hline
\end{tabular}




\begin{tabular}{|c|c|c|c|c|c|}
\hline 11 & No & $\mathrm{L}$ & $\mathrm{H}$ & 61.73628199 & 60.242 \\
\hline 11 & No & $\mathrm{H}$ & $\mathrm{L}$ & 89.59564125 & 70.831 \\
\hline 11 & No & $\mathrm{H}$ & $\mathrm{H}$ & 83.4865162 & 82.245 \\
\hline 11 & Yes & $\mathrm{L}$ & $\mathrm{L}$ & 78.20674084 & 73.731 \\
\hline 11 & Yes & $\mathrm{L}$ & $\mathrm{H}$ & 69.26052103 & 40.07 \\
\hline 11 & Yes & $\mathrm{H}$ & $\mathrm{L}$ & 121.347057 & 118.591 \\
\hline 11 & Yes & $\mathrm{H}$ & $\mathrm{H}$ & 98.56727237 & 78.43 \\
\hline 12 & No & $\mathrm{L}$ & $\mathrm{L}$ & 14.3861797 & 9.918 \\
\hline 12 & No & $\mathrm{L}$ & $\mathrm{H}$ & 19.85059042 & 16.48 \\
\hline 12 & No & $\mathrm{H}$ & $\mathrm{L}$ & 24.35236762 & 18.25 \\
\hline 12 & No & $\mathrm{H}$ & $\mathrm{H}$ & 29.00126841 & 25.513 \\
\hline 12 & Yes & $\mathrm{L}$ & $\mathrm{L}$ & 33.53838497 & 26.367 \\
\hline 12 & Yes & $\mathrm{L}$ & $\mathrm{H}$ & 23.06061545 & 17.639 \\
\hline 12 & Yes & $\mathrm{H}$ & $\mathrm{L}$ & 42.11196481 & 35.126 \\
\hline 12 & Yes & $H$ & $\mathrm{H}$ & 41.85808448 & 31.22 \\
\hline 13 & No & $\mathrm{L}$ & $\mathrm{L}$ & 38.93544572 & 38.727 \\
\hline 13 & No & $\mathrm{L}$ & $\mathrm{H}$ & 70.52255505 & 75.501 \\
\hline 13 & No & $\mathrm{H}$ & $\mathrm{L}$ & 58.07118414 & 42.572 \\
\hline 13 & No & $\mathrm{H}$ & $\mathrm{H}$ & 38.18882031 & 35.584 \\
\hline 13 & Yes & $\mathrm{L}$ & $\mathrm{L}$ & 123.3120495 & 99.609 \\
\hline 13 & Yes & $\mathrm{L}$ & $\mathrm{H}$ & 100.2237636 & 104.431 \\
\hline 13 & Yes & $\mathrm{H}$ & $\mathrm{L}$ & 135.1376298 & 99.091 \\
\hline 13 & Yes & $\mathrm{H}$ & $\mathrm{H}$ & 119.709311 & 114.166 \\
\hline 14 & No & $\mathrm{L}$ & $\mathrm{L}$ & 27.43982092 & 25.513 \\
\hline 14 & No & $\mathrm{L}$ & $\mathrm{H}$ & 38.32061212 & 37.323 \\
\hline 14 & No & $\mathrm{H}$ & $\mathrm{L}$ & 45.63785755 & 42.542 \\
\hline 14 & No & $\mathrm{H}$ & $\mathrm{H}$ & 41.14344211 & 36.774 \\
\hline 14 & Yes & $\mathrm{L}$ & $\mathrm{L}$ & 75.88178439 & 54.749 \\
\hline 14 & Yes & $\mathrm{L}$ & $\mathrm{H}$ & 70.44434983 & 42.725 \\
\hline 14 & Yes & $\mathrm{H}$ & $\mathrm{L}$ & 54.87490044 & 48.889 \\
\hline 14 & Yes & $\mathrm{H}$ & $\mathrm{H}$ & 62.93425561 & 52.063 \\
\hline 18 & No & $\mathrm{L}$ & $\mathrm{L}$ & 66.42258541 & 65.521 \\
\hline 18 & No & $\mathrm{L}$ & $\mathrm{H}$ & 39.42941438 & 35.736 \\
\hline 18 & No & $\mathrm{H}$ & $\mathrm{L}$ & 22.7706791 & 19.165 \\
\hline 18 & No & $\mathrm{H}$ & $\mathrm{H}$ & 27.21031391 & 22.766 \\
\hline 18 & Yes & $\mathrm{L}$ & $\mathrm{L}$ & 98.50621251 & 92.133 \\
\hline 18 & Yes & $\mathrm{L}$ & $\mathrm{H}$ & 51.34269977 & 31.799 \\
\hline 18 & Yes & $\mathrm{H}$ & $\mathrm{L}$ & 50.41402563 & 44.067 \\
\hline 18 & Yes & $\mathrm{H}$ & $\mathrm{H}$ & 51.40001126 & 44.128 \\
\hline
\end{tabular}




\begin{tabular}{|r|l|l|l|r|r|}
19 & No & L & L & 129.2894278 & 124.42 \\
\hline 19 & No & L & H & 130.7970169 & 113.709 \\
\hline 19 & No & H & L & 107.2382193 & 109.802 \\
\hline 19 & No & H & H & 83.63249494 & 77.774 \\
\hline 19 & Yes & L & L & 115.0193438 & 104.157 \\
\hline 19 & Yes & L & H & 164.0652437 & 133.9265 \\
\hline 19 & Yes & H & L & 76.07406799 & 69.5345 \\
\hline 19 & Yes & H & H & 79.302882 & 73.12 \\
\hline 20 & No & L & L & 66.49757264 & 65.399 \\
\hline 20 & No & L & H & 28.26730502 & 23.224 \\
\hline 20 & No & H & L & 56.24173025 & 46.753 \\
\hline 20 & No & H & H & 72.55096068 & 68.665 \\
\hline 20 & Yes & L & L & 119.2960833 & 82.367 \\
\hline 20 & Yes & L & H & 126.6544362 & 87.25 \\
\hline 20 & Yes & H & L & 112.1866681 & 65.2925 \\
\hline 20 & Yes & H & H & 113.9623578 & 77.24 \\
\hline 21 & No & L & L & 38.32614415 & 24.719 \\
\hline 21 & No & L & H & 29.46087393 & 20.447 \\
\hline 21 & No & H & L & 39.24234043 & 35.584 \\
\hline 21 & No & H & H & 48.57284516 & 43.06 \\
\hline 21 & Yes & L & L & 55.91218553 & 38.3 \\
\hline 21 & Yes & L & H & 76.78669637 & 53.396 \\
\hline 21 & Yes & H & L & 86.72020077 & 45.227 \\
\hline 21 & Yes & H & H & 66.36719751 & \\
\hline & & & & & \\
\hline
\end{tabular}




\section{Appendix F: Blood Perfusion Data Table (Intermediate Exertion V.S. Exertion)}

\begin{tabular}{|c|c|c|c|c|c|}
\hline Subject & Exertion & Temp & Humidity & $\begin{array}{c}\text { Blood Perfusion } \\
\text { Mean }\end{array}$ & $\begin{array}{c}\text { Blood Perfusion } \\
\text { Median }\end{array}$ \\
\hline 1 & $\begin{array}{l}\text { Intermediate } \\
\text { Exertion }\end{array}$ & $\mathrm{L}$ & $\mathrm{L}$ & 111.8940286 & 96.069 \\
\hline 1 & $\begin{array}{l}\text { Intermediate } \\
\text { Exertion }\end{array}$ & $\mathrm{L}$ & $\mathrm{H}$ & 104.4108643 & 92.651 \\
\hline 1 & $\begin{array}{l}\text { Intermediate } \\
\text { Exertion }\end{array}$ & $\mathrm{H}$ & $\mathrm{L}$ & 111.481791 & 80.841 \\
\hline 1 & $\begin{array}{l}\text { Intermediate } \\
\text { Exertion }\end{array}$ & $\mathrm{H}$ & $\mathrm{H}$ & 142.9353145 & 109.1765 \\
\hline 1 & Yes & $\mathrm{L}$ & $\mathrm{L}$ & 82.428402 & 69.702 \\
\hline 1 & Yes & $\mathrm{L}$ & $\mathrm{H}$ & 94.46378747 & 83.283 \\
\hline 1 & Yes & $\mathrm{H}$ & $\mathrm{L}$ & 108.9643961 & 87.586 \\
\hline 1 & Yes & $\mathrm{H}$ & $\mathrm{H}$ & 137.8636076 & 107.712 \\
\hline 2 & $\begin{array}{l}\text { Intermediate } \\
\text { Exertion }\end{array}$ & $\mathrm{L}$ & $\mathrm{L}$ & 65.6507781 & 39.124 \\
\hline 2 & $\begin{array}{l}\text { Intermediate } \\
\text { Exertion }\end{array}$ & $\mathrm{L}$ & $\mathrm{H}$ & 65.96761436 & 21.851 \\
\hline 2 & $\begin{array}{l}\text { Intermediate } \\
\text { Exertion }\end{array}$ & $\mathrm{H}$ & $\mathrm{L}$ & 80.22532655 & 46.722 \\
\hline 2 & $\begin{array}{l}\text { Intermediate } \\
\text { Exertion }\end{array}$ & $\mathrm{H}$ & $\mathrm{H}$ & 70.36481851 & 40.741 \\
\hline 2 & Yes & $\mathrm{L}$ & $\mathrm{L}$ & 53.04408781 & 36.499 \\
\hline 2 & Yes & $\mathrm{L}$ & $\mathrm{H}$ & 93.88106003 & 47.516 \\
\hline 2 & Yes & $\mathrm{H}$ & $\mathrm{L}$ & 70.39335486 & 58.9755 \\
\hline 2 & Yes & $\mathrm{H}$ & $\mathrm{H}$ & 77.21973879 & 67.23 \\
\hline 3 & $\begin{array}{l}\text { Intermediate } \\
\text { Exertion }\end{array}$ & $\mathrm{L}$ & $\mathrm{L}$ & 109.0189438 & 109.604 \\
\hline 3 & $\begin{array}{l}\text { Intermediate } \\
\text { Exertion }\end{array}$ & $\mathrm{L}$ & $\mathrm{H}$ & 70.68330062 & 45.136 \\
\hline 3 & $\begin{array}{l}\text { Intermediate } \\
\text { Exertion }\end{array}$ & $\mathrm{H}$ & $\mathrm{L}$ & 100.384919 & 106.781 \\
\hline 3 & $\begin{array}{l}\text { Intermediate } \\
\text { Exertion }\end{array}$ & $\mathrm{H}$ & $\mathrm{H}$ & 117.7301519 & 115.677 \\
\hline 3 & Yes & $\mathrm{L}$ & $\mathrm{L}$ & 18.07881178 & 10.651 \\
\hline 3 & Yes & $\mathrm{L}$ & $\mathrm{H}$ & 35.61185589 & 17.761 \\
\hline 3 & Yes & $\mathrm{H}$ & $\mathrm{L}$ & 45.24579163 & 31.479 \\
\hline 3 & Yes & $\mathrm{H}$ & $\mathrm{H}$ & 45.88284112 & 22.736 \\
\hline
\end{tabular}




\begin{tabular}{|c|c|c|c|c|c|}
\hline 4 & $\begin{array}{l}\text { Intermediate } \\
\text { Exertion }\end{array}$ & $\mathrm{L}$ & $\mathrm{L}$ & 128.7394434 & 126.068 \\
\hline 4 & $\begin{array}{l}\text { Intermediate } \\
\text { Exertion }\end{array}$ & $\mathrm{L}$ & $\mathrm{H}$ & 160.5080593 & 147.766 \\
\hline 4 & $\begin{array}{l}\text { Intermediate } \\
\text { Exertion }\end{array}$ & $\mathrm{H}$ & $\mathrm{L}$ & 148.5807408 & 138.214 \\
\hline 4 & $\begin{array}{l}\text { Intermediate } \\
\text { Exertion }\end{array}$ & $\mathrm{H}$ & $\mathrm{H}$ & 144.7399586 & 117.1725 \\
\hline 4 & Yes & $\mathrm{L}$ & $\mathrm{L}$ & 133.0119312 & 128.082 \\
\hline 4 & Yes & $\mathrm{L}$ & $\mathrm{H}$ & 146.6677333 & 134.964 \\
\hline 4 & Yes & $\mathrm{H}$ & $\mathrm{L}$ & 128.9382089 & 120.3 \\
\hline 4 & Yes & $\mathrm{H}$ & $\mathrm{H}$ & 159.2521841 & 150.055 \\
\hline 5 & $\begin{array}{l}\text { Intermediate } \\
\text { Exertion }\end{array}$ & $\mathrm{L}$ & $\mathrm{L}$ & 99.16936675 & 50.69 \\
\hline 5 & $\begin{array}{l}\text { Intermediate } \\
\text { Exertion }\end{array}$ & $\mathrm{L}$ & $\mathrm{H}$ & 79.98161949 & 67.535 \\
\hline 5 & $\begin{array}{l}\text { Intermediate } \\
\text { Exertion }\end{array}$ & $\mathrm{H}$ & $\mathrm{L}$ & 116.103183 & 73.7765 \\
\hline 5 & $\begin{array}{l}\text { Intermediate } \\
\text { Exertion }\end{array}$ & $\mathrm{H}$ & $\mathrm{H}$ & 109.1767056 & 66.254 \\
\hline 5 & Yes & $\mathrm{L}$ & $\mathrm{L}$ & 48.88306158 & 32.623 \\
\hline 5 & Yes & $\mathrm{L}$ & $\mathrm{H}$ & 74.89545365 & 66.834 \\
\hline 5 & Yes & $\mathrm{H}$ & $\mathrm{L}$ & 65.49795381 & 43.823 \\
\hline 5 & Yes & $\mathrm{H}$ & $\mathrm{H}$ & 93.13439506 & 50.049 \\
\hline 7 & $\begin{array}{l}\text { Intermediate } \\
\text { Exertion }\end{array}$ & $\mathrm{L}$ & $\mathrm{L}$ & 59.24885356 & 46.997 \\
\hline 7 & $\begin{array}{l}\text { Intermediate } \\
\text { Exertion }\end{array}$ & $\mathrm{L}$ & $\mathrm{H}$ & 72.96236775 & 51.27 \\
\hline 7 & $\begin{array}{l}\text { Intermediate } \\
\text { Exertion }\end{array}$ & $\mathrm{H}$ & $\mathrm{L}$ & 56.81975661 & 44.281 \\
\hline 7 & $\begin{array}{l}\text { Intermediate } \\
\text { Exertion }\end{array}$ & $\mathrm{H}$ & $\mathrm{H}$ & 78.06740207 & 70.191 \\
\hline 7 & Yes & $\mathrm{L}$ & $\mathrm{L}$ & 59.94203564 & 51.483 \\
\hline 7 & Yes & $\mathrm{L}$ & $\mathrm{H}$ & 61.20745207 & 52.277 \\
\hline 7 & Yes & $\mathrm{H}$ & $\mathrm{L}$ & 54.46316394 & 48.2025 \\
\hline 7 & Yes & $\mathrm{H}$ & $\mathrm{H}$ & 96.3058705 & 81.268 \\
\hline 8 & $\begin{array}{l}\text { Intermediate } \\
\text { Exertion }\end{array}$ & $\mathrm{L}$ & $\mathrm{L}$ & 39.0213912 & 26.52 \\
\hline 8 & $\begin{array}{l}\text { Intermediate } \\
\text { Exertion }\end{array}$ & $\mathrm{L}$ & $\mathrm{H}$ & 86.58609973 & 72.6775 \\
\hline 8 & $\begin{array}{l}\text { Intermediate } \\
\text { Exertion }\end{array}$ & $\mathrm{H}$ & $\mathrm{L}$ & 26.92420835 & 14.771 \\
\hline
\end{tabular}




\begin{tabular}{|c|c|c|c|c|c|}
\hline 8 & $\begin{array}{l}\text { Intermediate } \\
\text { Exertion }\end{array}$ & $\mathrm{H}$ & $\mathrm{H}$ & 47.42946217 & 32.471 \\
\hline 8 & Yes & $\mathrm{L}$ & $\mathrm{L}$ & 46.00946616 & 32.349 \\
\hline 8 & Yes & $\mathrm{L}$ & $\mathrm{H}$ & 47.09112314 & 32.166 \\
\hline 8 & Yes & $\mathrm{H}$ & $\mathrm{L}$ & 52.71060337 & 46.356 \\
\hline 8 & Yes & $\mathrm{H}$ & $\mathrm{H}$ & 72.40555269 & 60.822 \\
\hline 9 & $\begin{array}{l}\text { Intermediate } \\
\text { Exertion }\end{array}$ & $\mathrm{L}$ & $\mathrm{L}$ & 88.06141399 & 72.662 \\
\hline 9 & $\begin{array}{l}\text { Intermediate } \\
\text { Exertion }\end{array}$ & $\mathrm{L}$ & $\mathrm{H}$ & 74.72142699 & 63.141 \\
\hline 9 & $\begin{array}{l}\text { Intermediate } \\
\text { Exertion }\end{array}$ & $\mathrm{H}$ & $\mathrm{L}$ & 37.41677305 & 23.956 \\
\hline 9 & $\begin{array}{l}\text { Intermediate } \\
\text { Exertion }\end{array}$ & $\mathrm{H}$ & $\mathrm{H}$ & 39.39596094 & 30.426 \\
\hline 9 & Yes & $\mathrm{L}$ & $\mathrm{L}$ & 112.1171295 & 88.776 \\
\hline 9 & Yes & $\mathrm{L}$ & $\mathrm{H}$ & 53.66031615 & 32.684 \\
\hline 9 & Yes & $\mathrm{H}$ & $\mathrm{L}$ & 55.18999897 & 47.302 \\
\hline 9 & Yes & $\mathrm{H}$ & $\mathrm{H}$ & 52.06474217 & 42.816 \\
\hline 10 & $\begin{array}{l}\text { Intermediate } \\
\text { Exertion }\end{array}$ & $\mathrm{L}$ & $\mathrm{L}$ & 70.5604673 & 40.039 \\
\hline 10 & $\begin{array}{l}\text { Intermediate } \\
\text { Exertion }\end{array}$ & $\mathrm{L}$ & $\mathrm{H}$ & 100.4063814 & 81.635 \\
\hline 10 & $\begin{array}{l}\text { Intermediate } \\
\text { Exertion }\end{array}$ & $\mathrm{H}$ & $\mathrm{L}$ & 109.6845757 & 89.417 \\
\hline 10 & $\begin{array}{l}\text { Intermediate } \\
\text { Exertion }\end{array}$ & $\mathrm{H}$ & $\mathrm{H}$ & 109.0461756 & 85.724 \\
\hline 10 & Yes & $\mathrm{L}$ & $\mathrm{L}$ & 81.99036199 & 59.143 \\
\hline 10 & Yes & $\mathrm{L}$ & $\mathrm{H}$ & 110.9052899 & 100.708 \\
\hline 10 & Yes & $\mathrm{H}$ & $\mathrm{L}$ & 87.62079425 & 74.005 \\
\hline 10 & Yes & $\mathrm{H}$ & $\mathrm{H}$ & 86.06926173 & 68.665 \\
\hline 11 & $\begin{array}{l}\text { Intermediate } \\
\text { Exertion }\end{array}$ & $\mathrm{L}$ & $\mathrm{L}$ & 129.7278218 & 126.74 \\
\hline 11 & $\begin{array}{l}\text { Intermediate } \\
\text { Exertion }\end{array}$ & $\mathrm{L}$ & $\mathrm{H}$ & 114.5712624 & 103.333 \\
\hline 11 & $\begin{array}{l}\text { Intermediate } \\
\text { Exertion }\end{array}$ & $\mathrm{H}$ & $\mathrm{L}$ & 207.5155393 & 191.437 \\
\hline 11 & $\begin{array}{l}\text { Intermediate } \\
\text { Exertion }\end{array}$ & $\mathrm{H}$ & $\mathrm{H}$ & 172.6805366 & 156.937 \\
\hline 11 & Yes & $\mathrm{L}$ & $\mathrm{L}$ & 26.69098336 & 14.771 \\
\hline 11 & Yes & $\mathrm{L}$ & $\mathrm{H}$ & 23.940415 & 10.742 \\
\hline 11 & Yes & $\mathrm{H}$ & $\mathrm{L}$ & 35.16967035 & 14.679 \\
\hline 11 & Yes & $\mathrm{H}$ & $\mathrm{H}$ & 24.45400816 & 14.557 \\
\hline
\end{tabular}




\begin{tabular}{|c|c|c|c|c|c|}
\hline 12 & $\begin{array}{l}\text { Intermediate } \\
\text { Exertion }\end{array}$ & $\mathrm{L}$ & $\mathrm{L}$ & 28.95590034 & 21.668 \\
\hline 12 & $\begin{array}{l}\text { Intermediate } \\
\text { Exertion }\end{array}$ & $\mathrm{L}$ & $\mathrm{H}$ & 18.46066432 & 11.871 \\
\hline 12 & $\begin{array}{c}\text { Intermediate } \\
\text { Exertion }\end{array}$ & $\mathrm{H}$ & $\mathrm{L}$ & 33.46604485 & 19.501 \\
\hline 12 & $\begin{array}{l}\text { Intermediate } \\
\text { Exertion }\end{array}$ & $\mathrm{H}$ & $\mathrm{H}$ & 34.64949778 & 17.181 \\
\hline 12 & Yes & $\mathrm{L}$ & $\mathrm{L}$ & 38.74018962 & 30.945 \\
\hline 12 & Yes & $\mathrm{L}$ & $\mathrm{H}$ & 27.66199277 & 22.614 \\
\hline 12 & Yes & $\mathrm{H}$ & $\mathrm{L}$ & 50.75609806 & 43.549 \\
\hline 12 & Yes & $\mathrm{H}$ & $\mathrm{H}$ & 49.06667118 & 40.588 \\
\hline 13 & $\begin{array}{l}\text { Intermediate } \\
\text { Exertion }\end{array}$ & $\mathrm{L}$ & $\mathrm{L}$ & 106.9707894 & 77.9265 \\
\hline 13 & $\begin{array}{l}\text { Intermediate } \\
\text { Exertion }\end{array}$ & $\mathrm{L}$ & $\mathrm{H}$ & 88.38253219 & 69.367 \\
\hline 13 & $\begin{array}{l}\text { Intermediate } \\
\text { Exertion }\end{array}$ & $\mathrm{H}$ & $\mathrm{L}$ & 111.6712666 & 89.722 \\
\hline 13 & $\begin{array}{l}\text { Intermediate } \\
\text { Exertion }\end{array}$ & $\mathrm{H}$ & $\mathrm{H}$ & 72.11317192 & 60.12 \\
\hline 13 & Yes & $\mathrm{L}$ & $\mathrm{L}$ & 139.6533097 & 115.234 \\
\hline 13 & Yes & $\mathrm{L}$ & $\mathrm{H}$ & 112.0949081 & 123.3065 \\
\hline 13 & Yes & $\mathrm{H}$ & $\mathrm{L}$ & 145.570348 & 132.63 \\
\hline 13 & Yes & $\mathrm{H}$ & $\mathrm{H}$ & 101.080334 & 103.058 \\
\hline 14 & $\begin{array}{l}\text { Intermediate } \\
\text { Exertion }\end{array}$ & $\mathrm{L}$ & $\mathrm{L}$ & 58.63532913 & 44.861 \\
\hline 14 & $\begin{array}{l}\text { Intermediate } \\
\text { Exertion }\end{array}$ & $\mathrm{L}$ & $\mathrm{H}$ & 43.39822641 & 24.323 \\
\hline 14 & $\begin{array}{l}\text { Intermediate } \\
\text { Exertion }\end{array}$ & $\mathrm{H}$ & $\mathrm{L}$ & 53.97931859 & 43.579 \\
\hline 14 & $\begin{array}{l}\text { Intermediate } \\
\text { Exertion }\end{array}$ & $\mathrm{H}$ & $\mathrm{H}$ & 47.149836 & 36.041 \\
\hline 14 & Yes & $\mathrm{L}$ & $\mathrm{L}$ & 93.12823964 & 78.766 \\
\hline 14 & Yes & $\mathrm{L}$ & $\mathrm{H}$ & 97.48767865 & 86.2885 \\
\hline 14 & Yes & $\mathrm{H}$ & $\mathrm{L}$ & 55.77038975 & 51.331 \\
\hline 14 & Yes & $\mathrm{H}$ & $\mathrm{H}$ & 78.71867521 & 65.491 \\
\hline 18 & $\begin{array}{l}\text { Intermediate } \\
\text { Exertion }\end{array}$ & $\mathrm{L}$ & $\mathrm{L}$ & 125.3867583 & 128.937 \\
\hline 18 & $\begin{array}{l}\text { Intermediate } \\
\text { Exertion }\end{array}$ & $\mathrm{L}$ & $\mathrm{H}$ & 44.61736584 & 35.614 \\
\hline 18 & $\begin{array}{l}\text { Intermediate } \\
\text { Exertion }\end{array}$ & $\mathrm{H}$ & $\mathrm{L}$ & 54.66864314 & 51.361 \\
\hline
\end{tabular}




\begin{tabular}{|c|c|c|c|c|c|}
\hline 18 & $\begin{array}{l}\text { Intermediate } \\
\text { Exertion }\end{array}$ & $\mathrm{H}$ & $\mathrm{H}$ & 51.28188574 & 41.809 \\
\hline 18 & Yes & $\mathrm{L}$ & $\mathrm{L}$ & 71.42751969 & 65.979 \\
\hline 18 & Yes & $\mathrm{L}$ & $\mathrm{H}$ & 58.07011885 & 28.5795 \\
\hline 18 & Yes & $\mathrm{H}$ & $\mathrm{L}$ & 46.15808898 & 39.917 \\
\hline 18 & Yes & $\mathrm{H}$ & $\mathrm{H}$ & 51.51819783 & 45.593 \\
\hline 19 & $\begin{array}{l}\text { Intermediate } \\
\text { Exertion }\end{array}$ & $\mathrm{L}$ & $\mathrm{L}$ & 131.3126823 & 107.941 \\
\hline 19 & $\begin{array}{l}\text { Intermediate } \\
\text { Exertion }\end{array}$ & $\mathrm{L}$ & $\mathrm{H}$ & 174.0890043 & 129.212 \\
\hline 19 & $\begin{array}{l}\text { Intermediate } \\
\text { Exertion }\end{array}$ & $\mathrm{H}$ & $\mathrm{L}$ & 83.69737997 & 73.914 \\
\hline 19 & $\begin{array}{c}\text { Intermediate } \\
\text { Exertion }\end{array}$ & $\mathrm{H}$ & $\mathrm{H}$ & 82.75723285 & 76.935 \\
\hline 19 & Yes & $\mathrm{L}$ & $\mathrm{L}$ & 98.7209537 & 101.12 \\
\hline 19 & Yes & $\mathrm{L}$ & $\mathrm{H}$ & 154.0394114 & 135.529 \\
\hline 19 & Yes & $\mathrm{H}$ & $\mathrm{L}$ & 68.45233123 & 66.559 \\
\hline 19 & Yes & $\mathrm{H}$ & $\mathrm{H}$ & 75.84710314 & 69.641 \\
\hline 20 & $\begin{array}{l}\text { Intermediate } \\
\text { Exertion }\end{array}$ & $\mathrm{L}$ & $\mathrm{L}$ & 128.2079769 & 73.685 \\
\hline 20 & $\begin{array}{l}\text { Intermediate } \\
\text { Exertion }\end{array}$ & $\mathrm{L}$ & $\mathrm{H}$ & 147.930653 & 95.368 \\
\hline 20 & $\begin{array}{l}\text { Intermediate } \\
\text { Exertion }\end{array}$ & $\mathrm{H}$ & $\mathrm{L}$ & 156.952472 & 141.846 \\
\hline 20 & $\begin{array}{l}\text { Intermediate } \\
\text { Exertion }\end{array}$ & $\mathrm{H}$ & $\mathrm{H}$ & 144.8849881 & 121.155 \\
\hline 20 & Yes & $\mathrm{L}$ & $\mathrm{L}$ & 110.3832688 & 87.586 \\
\hline 20 & Yes & $\mathrm{L}$ & $\mathrm{H}$ & 105.3826162 & 83.313 \\
\hline 20 & Yes & $\mathrm{H}$ & $\mathrm{L}$ & 67.42086421 & 41.168 \\
\hline 20 & Yes & $\mathrm{H}$ & $\mathrm{H}$ & 83.04611716 & 48.035 \\
\hline 21 & $\begin{array}{l}\text { Intermediate } \\
\text { Exertion }\end{array}$ & $\mathrm{L}$ & $\mathrm{L}$ & 50.55555631 & 31.799 \\
\hline 21 & $\begin{array}{c}\text { Intermediate } \\
\text { Exertion }\end{array}$ & $\mathrm{L}$ & $\mathrm{H}$ & 65.46227844 & 40.192 \\
\hline 21 & $\begin{array}{l}\text { Intermediate } \\
\text { Exertion }\end{array}$ & $\mathrm{H}$ & $\mathrm{L}$ & 99.22301519 & 58.014 \\
\hline 21 & $\begin{array}{l}\text { Intermediate } \\
\text { Exertion }\end{array}$ & $\mathrm{H}$ & $\mathrm{H}$ & 81.24200527 & 60.089 \\
\hline 21 & Yes & $\mathrm{L}$ & $\mathrm{L}$ & 48.87933543 & 36.682 \\
\hline 21 & Yes & $\mathrm{L}$ & $\mathrm{H}$ & 68.32642151 & 43.427 \\
\hline 21 & Yes & $\mathrm{H}$ & $\mathrm{L}$ & 73.86392183 & 57.587 \\
\hline 21 & Yes & $\mathrm{H}$ & $\mathrm{H}$ & 51.49853636 & 40.161 \\
\hline
\end{tabular}




\section{Appendix G: Skin Conductance Normality Test}






\section{Appendix H: Normalized Skin Conductance Normality Test}

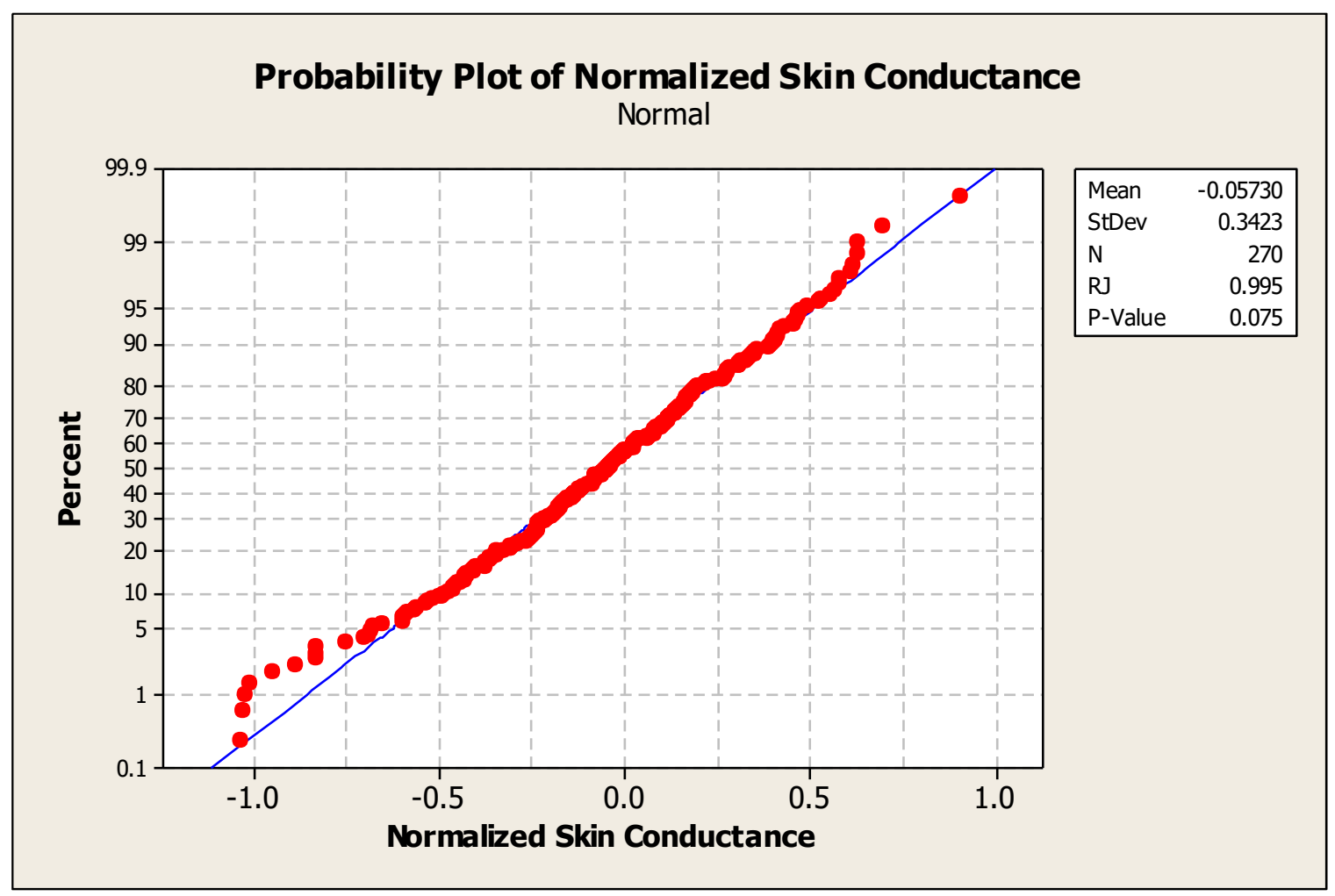




\section{Appendix I: Normalized Skin Conductance Equality of Variance Test}






\section{Appendix J: Perceived Discomfort Normality Test}

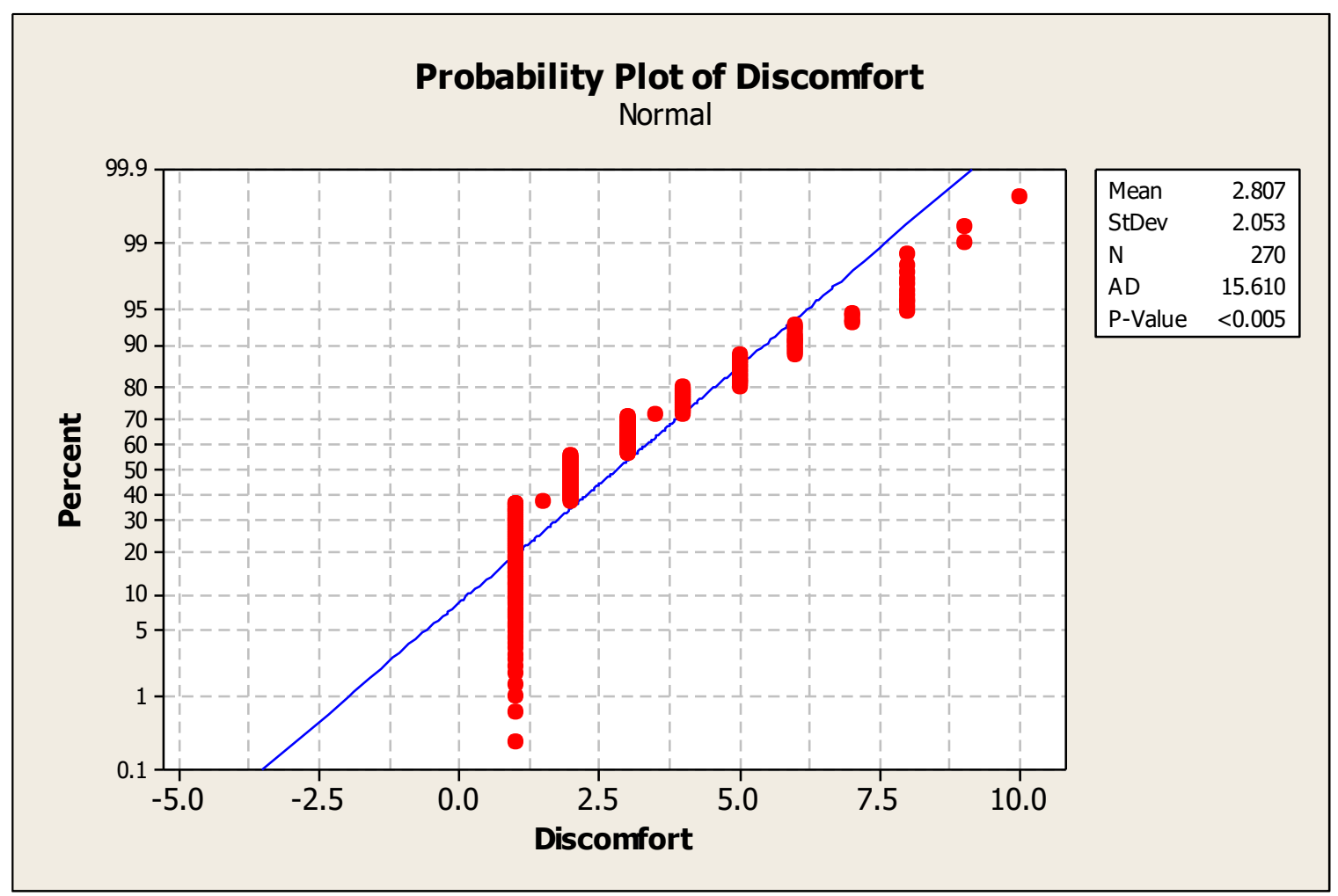




\section{Appendix K: Normalized Perceived Discomfort Normality Test}

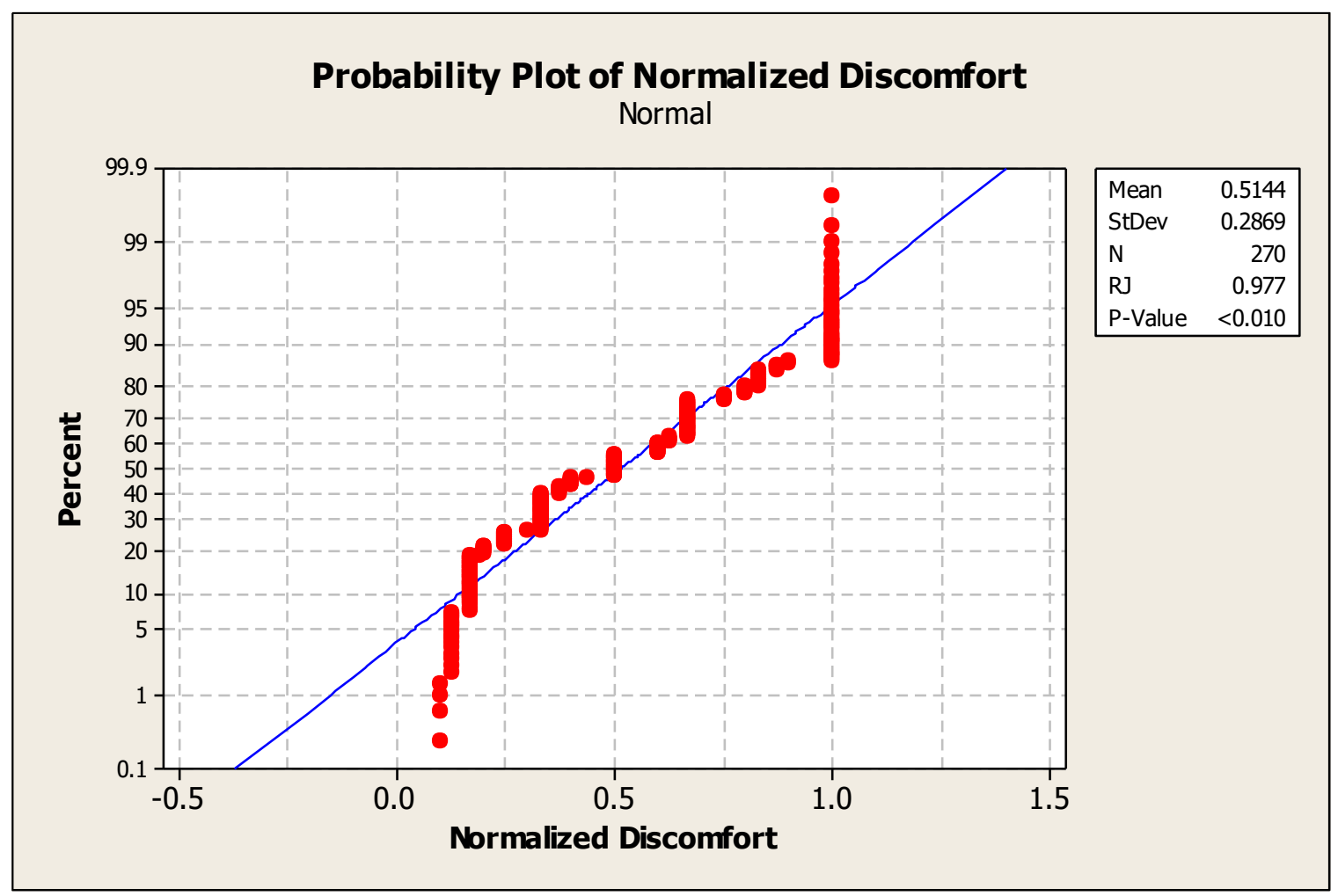




\section{Appendix L: Normalized Perceived Discomfort Equality of Variance Test}






\section{Appendix M: Blood Perfusion (Exertion Trial V.S. No Exertion Trial) Equality of Variance Test}

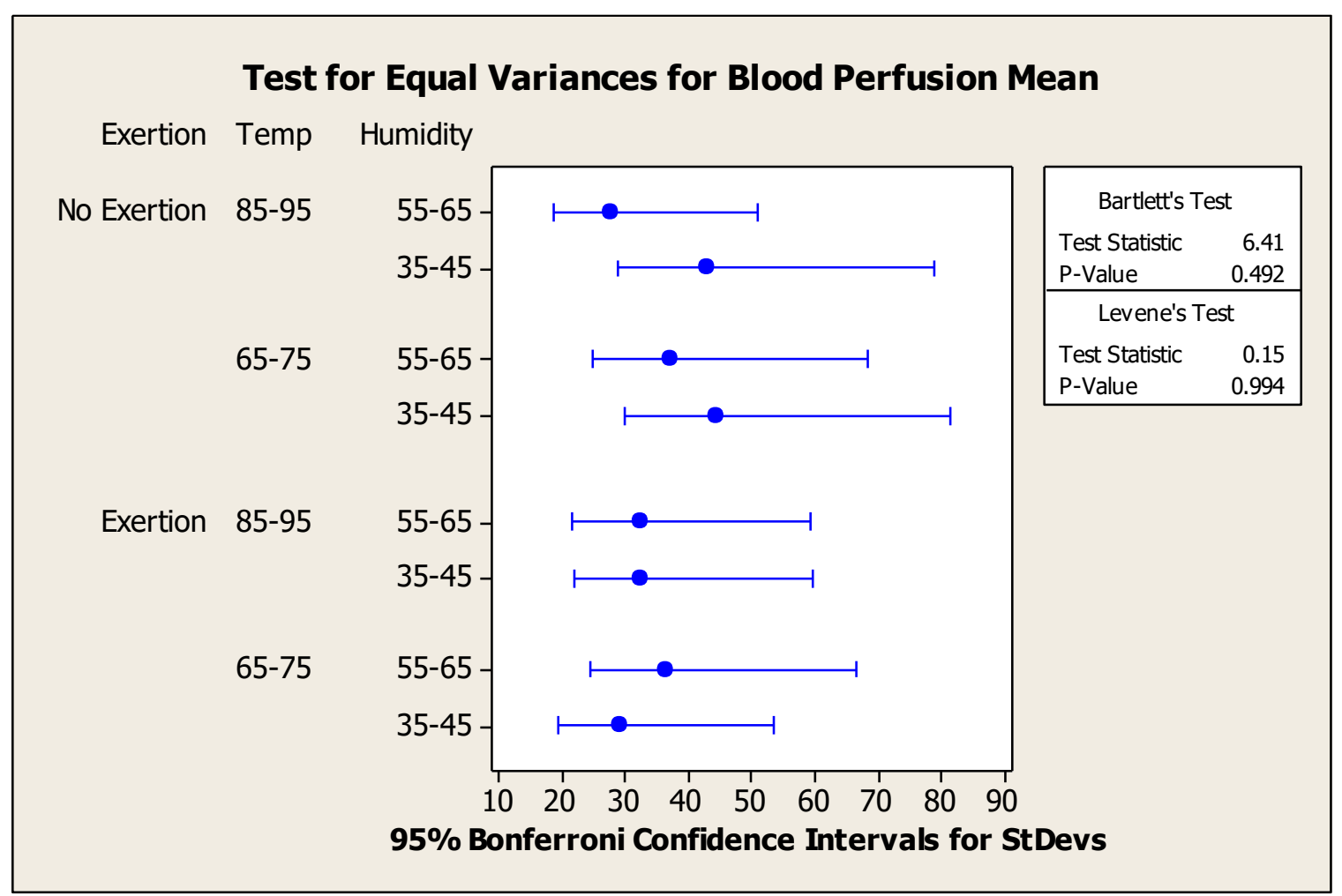




\section{Appendix N: Blood Perfusion (Exertion V.S. Intermediate Exertion) Equality of Variance Test}

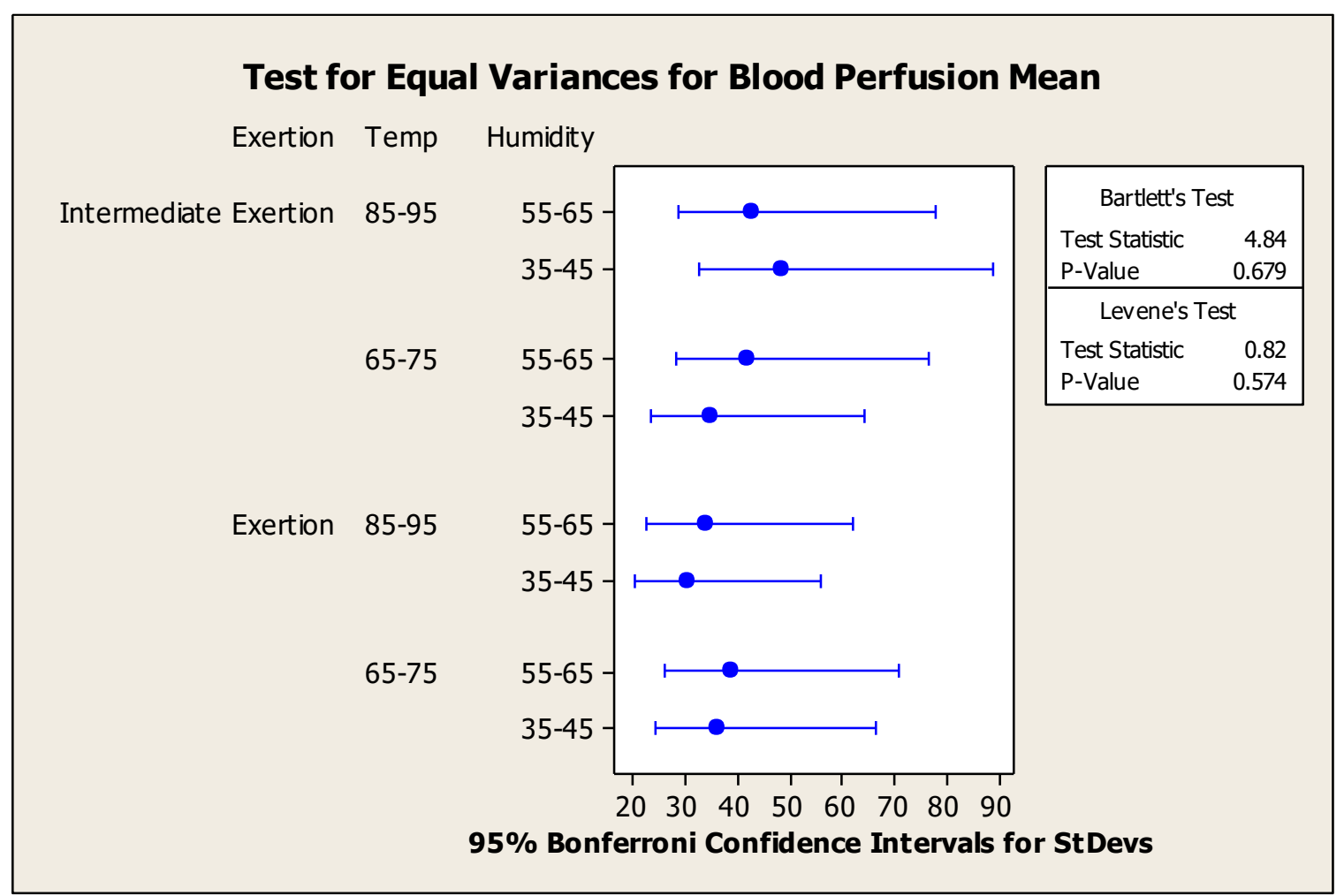




\section{Appendix O: Blood Perfusion (Exertion Trial V.S. No Exertion Trial) Normality of Residuals}

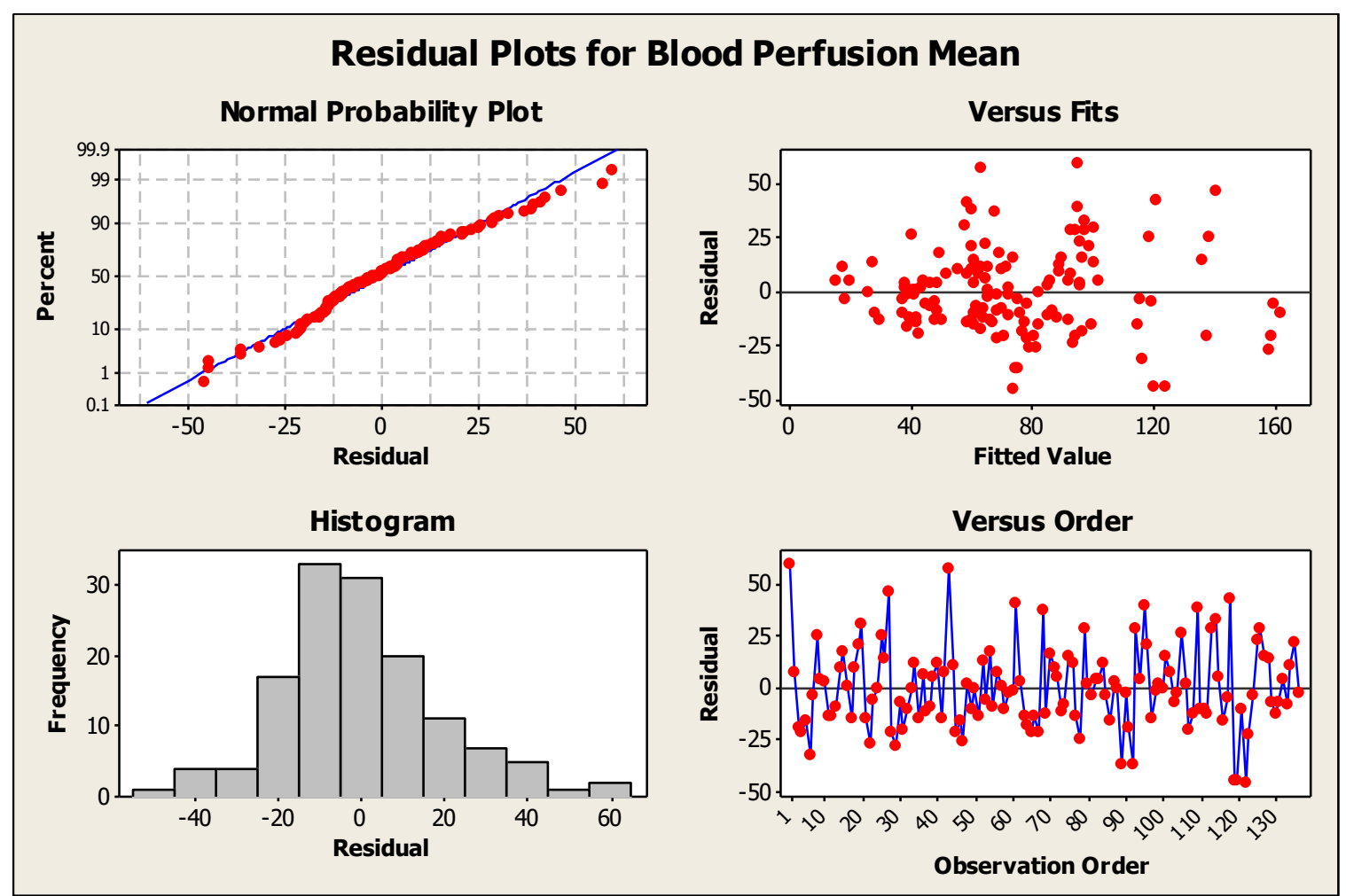




\section{Appendix P: Blood Perfusion (Exertion V.S. Intermediate Exertion) Normality of Residuals}



